\title{
Estrutura \\ do \\ Direito Internacional
}

Braz de Sousa Arruda

(Preleções feitas no Curso de Doutorado) 
"O peyor officio que ha no mundo he ser author de novidades, que muitas vezes, por alguns respeitos, não contentam a muitos homens, porque a cousa que se faz para contentar a muitos, he a que descontenta a muitos" - (Diogo DE Couto - Soldado Pratico - MDCCXC).

" $E$ ' merito d'un libro il dar la volontá di sapere piú di quello che esso insegna" - (A. MaNzonI - Opp. Varie, I, 487).

"Like all other law, international Law rest, in the last instance, upon an ethical basis" - (AXEL MöLleR - International Law, p. 55). 


\section{N D I C E}

0 estudo moderno do direito internacional $\ldots \ldots \ldots \ldots \ldots \ldots \ldots \ldots . \ldots 5$

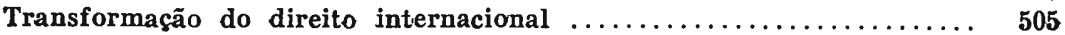

Dificuldade do ensino do direito internacional ................. 505

Condições desfavoraveis para o desenvolvimento do direito internacional

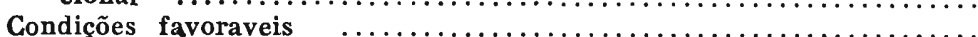

Tendências do direito internacional $\ldots \ldots \ldots \ldots \ldots \ldots \ldots \ldots \ldots \ldots, 507$

Como ensinar o direito internacional $\ldots \ldots \ldots \ldots \ldots \ldots \ldots \ldots \ldots, 507$

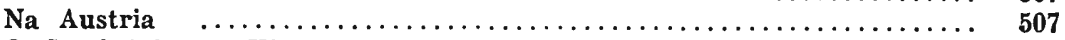

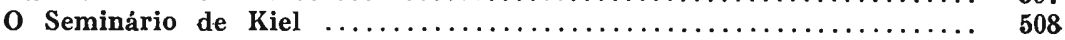

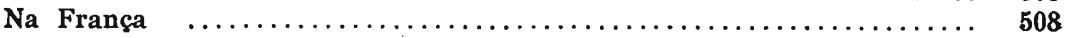

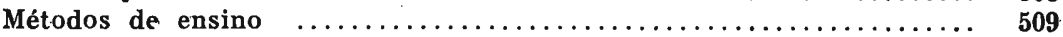

Na América do Norte ................................. 509

Conclusão $\ldots \ldots \ldots \ldots \ldots \ldots \ldots \ldots \ldots \ldots \ldots \ldots \ldots \ldots \ldots \ldots \ldots \ldots \ldots, \quad 509$

Entre nós $\ldots \ldots \ldots \ldots \ldots \ldots \ldots \ldots \ldots \ldots \ldots \ldots \ldots \ldots \ldots \ldots \ldots \ldots \ldots \ldots \ldots, \quad 509$

Como devemos ensinar o direito internacional $\ldots \ldots \ldots \ldots \ldots \ldots \ldots, 510$

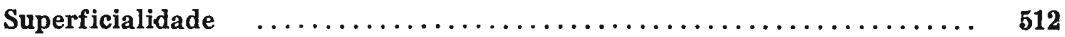

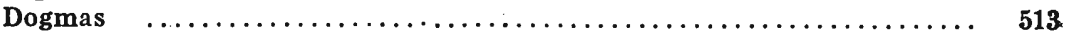

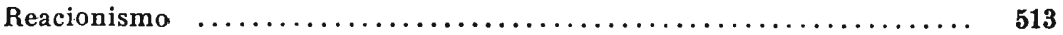

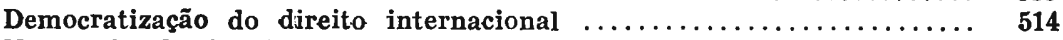

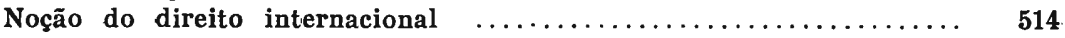

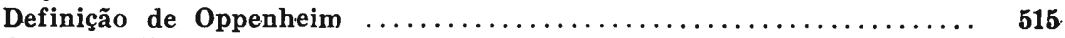

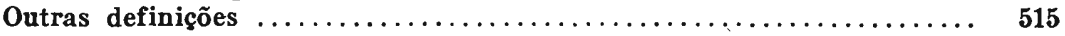

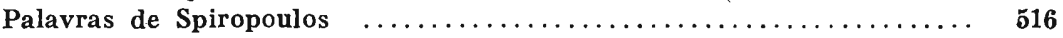

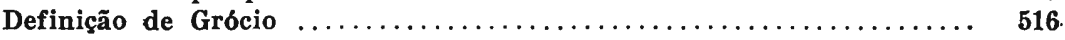

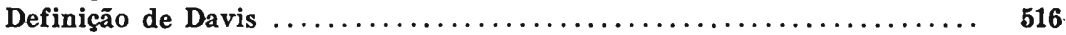

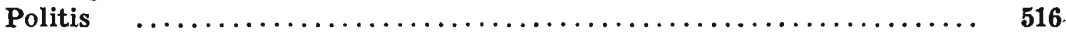

Definição de um notavel internacionalista brasileiro $\ldots \ldots \ldots \ldots \ldots \ldots .517$

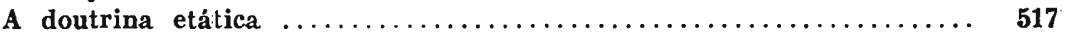

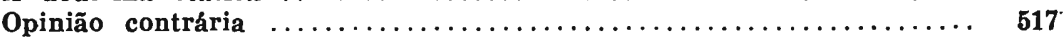

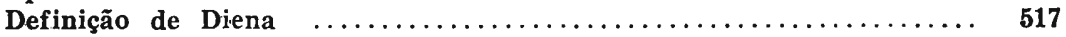

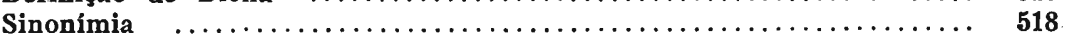

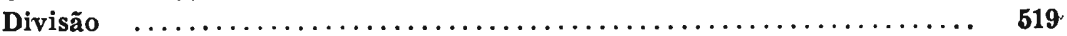

Objeções contra a existência do direito internacional $\ldots \ldots \ldots \ldots \ldots .521$

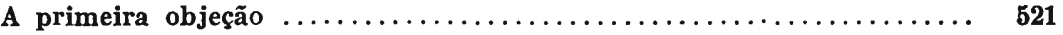

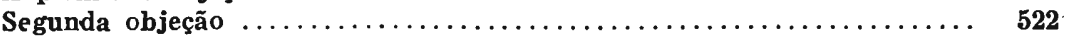

Importância das objeçóes contra a existência do direito internacional 523:

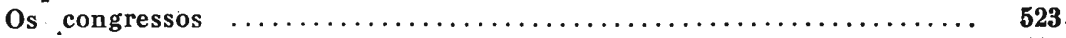

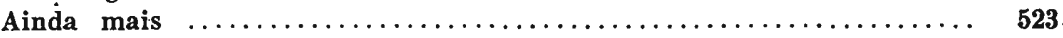

0 direito internacional e a opinião pública mundial $\ldots \ldots \ldots \ldots \ldots \ldots .524$

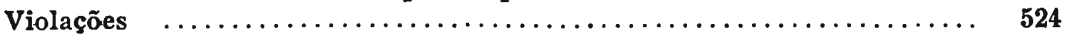

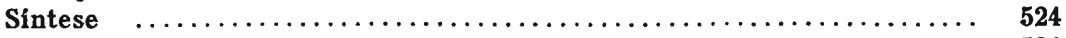

Fundamento $\quad \ldots \ldots \ldots \ldots \ldots \ldots \ldots \ldots \ldots \ldots \ldots \ldots \ldots \ldots \ldots \ldots \ldots \ldots \ldots, \quad 524$

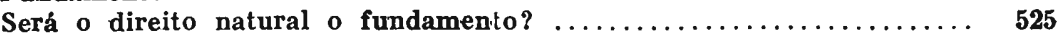

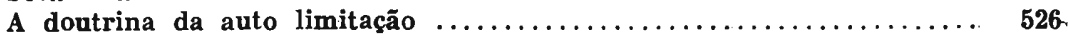




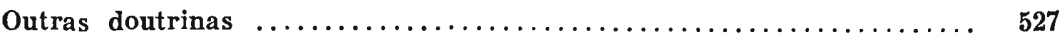

A regra fundamental suprema fundamento do direito internacional .. 528

Fundamento do direito internacional ....................... 529

Característicos das regras ou normas jurídicas .................. 529

o consentimento comum ............................... 530

Consentimento comum na família das nações ................... 531

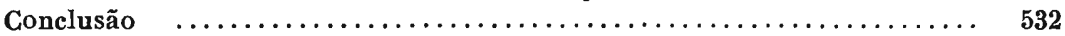

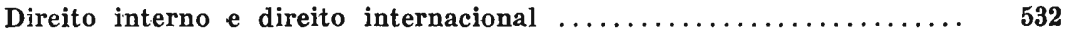

Ataques à doutrina dualista $\ldots \ldots \ldots \ldots \ldots \ldots \ldots \ldots \ldots \ldots \ldots \ldots \ldots \ldots \ldots, 534$

A doutrina anglo-americana $\ldots \ldots \ldots \ldots \ldots \ldots \ldots \ldots \ldots \ldots \ldots \ldots \ldots \ldots \ldots, 535$

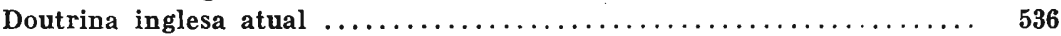

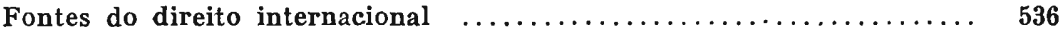

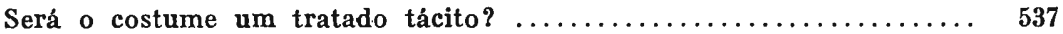

Domínio do direito internacional $\ldots \ldots \ldots \ldots \ldots \ldots \ldots \ldots \ldots \ldots, 539$

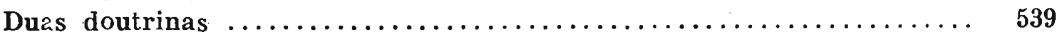

Falsidade dessas doutrinas $\ldots \ldots \ldots \ldots \ldots \ldots \ldots \ldots \ldots \ldots \ldots \ldots \ldots, 539$

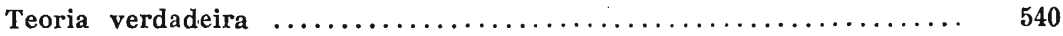

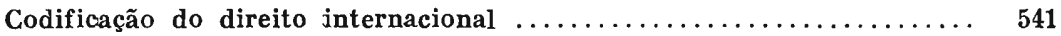

o Código Bustamante .................................. 542

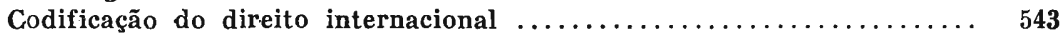

Será possivel a codificação do direito internacional .............. 544

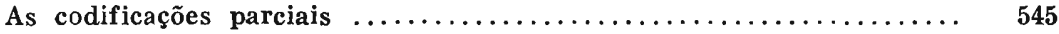

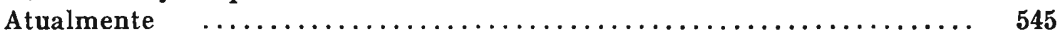

o maior obstáculo à codificação do direito internacional $\ldots \ldots \ldots \ldots \ldots .546$

História do direito internacional $\ldots \ldots \ldots \ldots \ldots \ldots \ldots \ldots \ldots \ldots, 547$

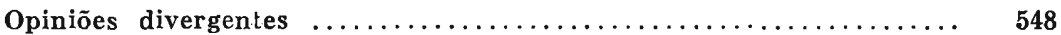

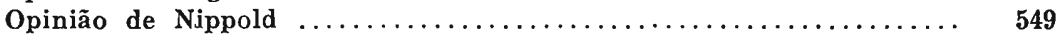

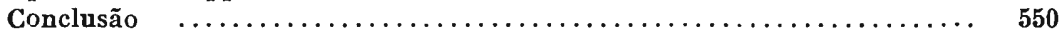

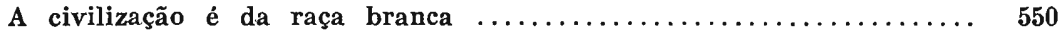

Divisão da história do direito internacional $\ldots \ldots \ldots \ldots \ldots \ldots \ldots \ldots .6 . \ldots 52$

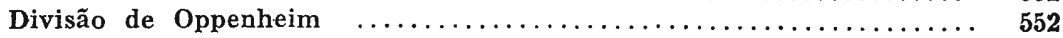

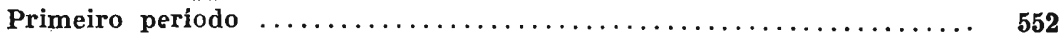

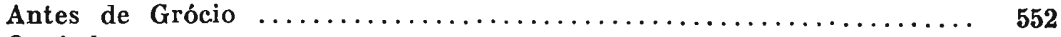

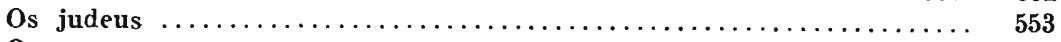

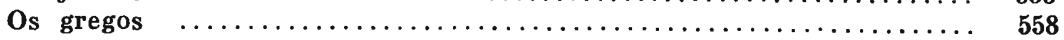

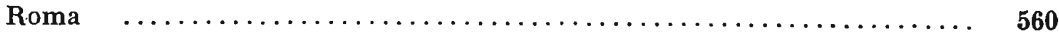

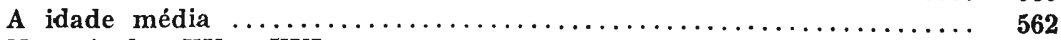

Nos séculos XV e XVI .................................. 565

Fatores que influiram no desenvolvimento do direito internacional nes-

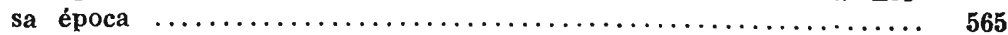

Segundo periodo -0 direito internacional depois de Grócio ...... 570

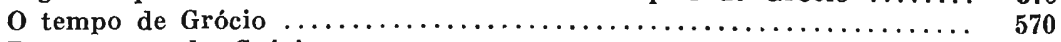

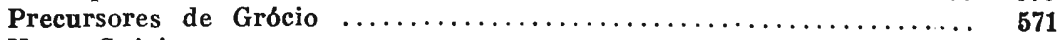

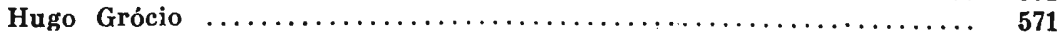

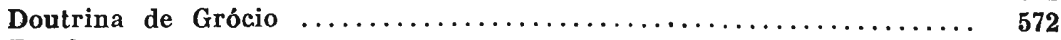

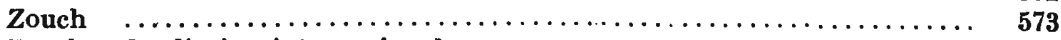

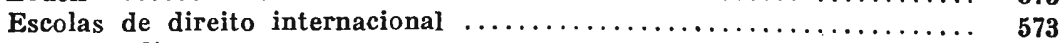

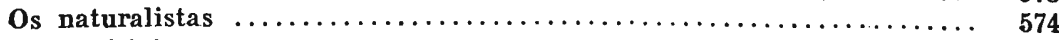

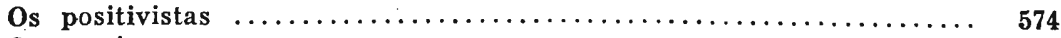

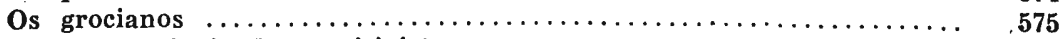

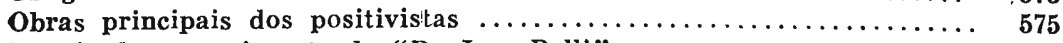

Depois do aparecimento do "De Jure Belli" $\ldots \ldots \ldots \ldots \ldots \ldots \ldots \ldots .576$

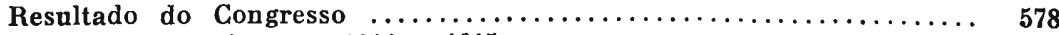

Congresso de Viena -1814 e $1815 \ldots \ldots \ldots \ldots \ldots \ldots \ldots \ldots \ldots \ldots \ldots \ldots . \ldots \ldots$ 
1918

Lições da história do direito internacional $\ldots \ldots \ldots \ldots \ldots \ldots \ldots \ldots \ldots$

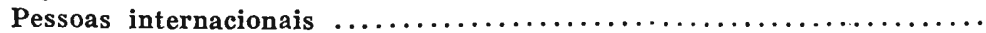

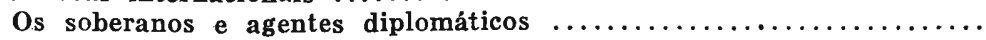

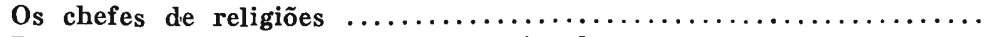

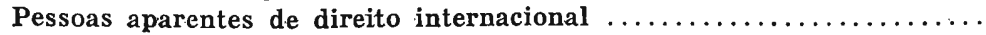

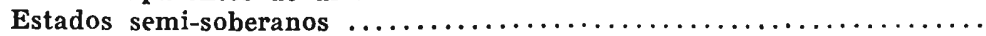

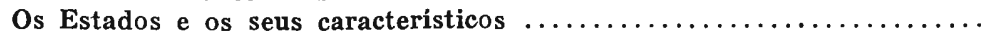

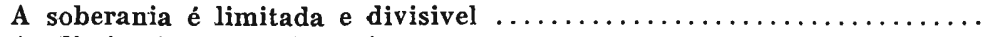

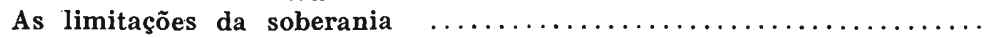

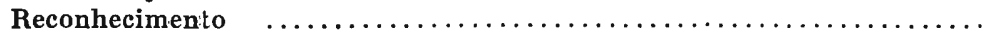

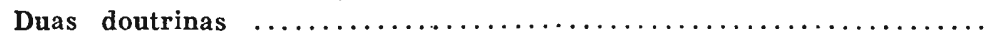

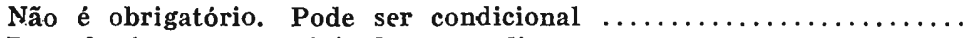

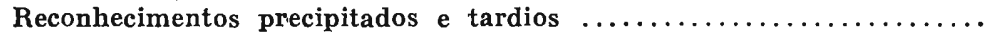

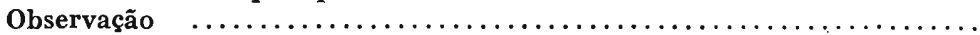

Mudança na condição das pessoas internacionais $\ldots \ldots \ldots \ldots \ldots \ldots$.

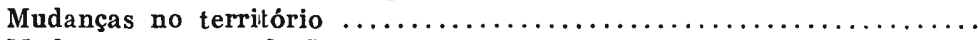

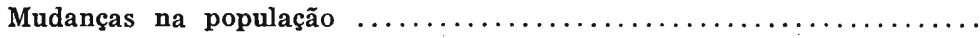

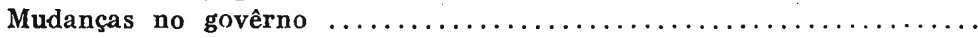

Mudanças que afetam a personalidade internacional $\ldots \ldots \ldots \ldots \ldots \ldots$

Estado neutralizado permanentemente $\ldots \ldots \ldots \ldots \ldots \ldots \ldots \ldots \ldots \ldots$

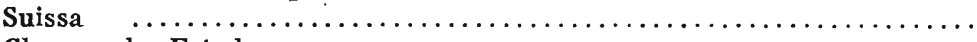

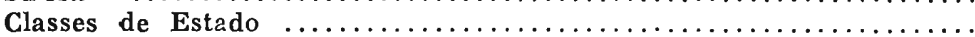

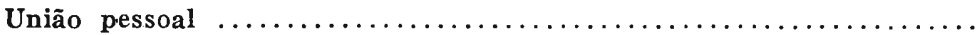

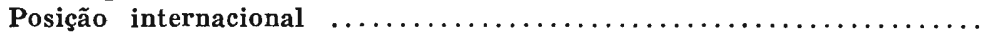

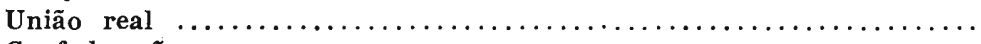

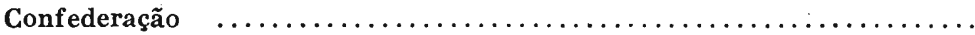

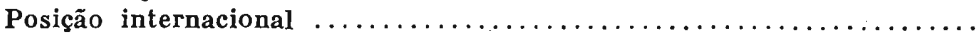

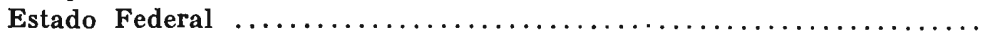

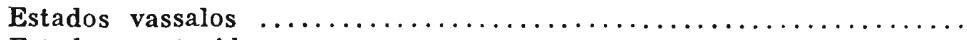

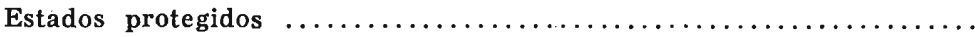

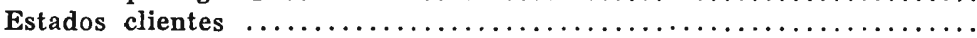

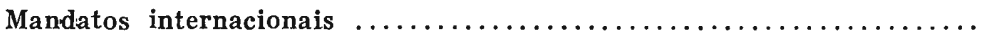

Posição internacional de outros Estados $\ldots \ldots \ldots \ldots \ldots \ldots \ldots \ldots \ldots$

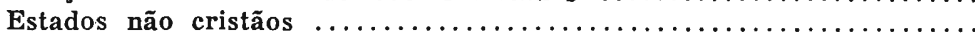

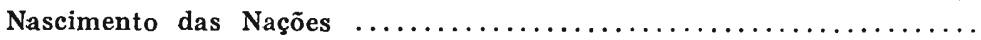

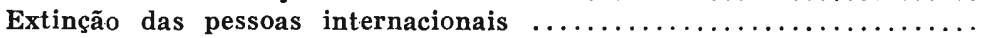

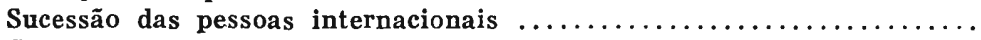

Casos

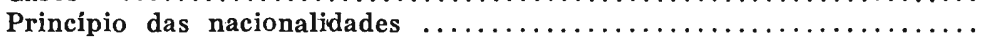

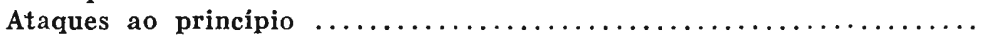

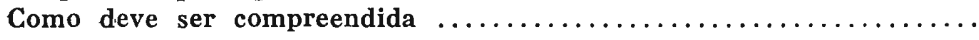

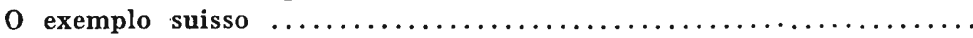

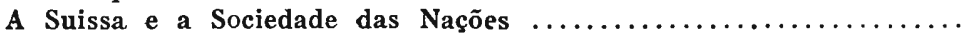

A grande guerra e o problema das nacionalidades $\ldots \ldots \ldots \ldots \ldots \ldots, 613$

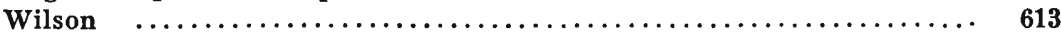

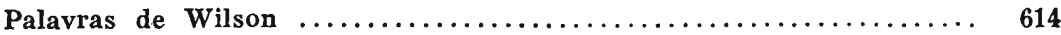

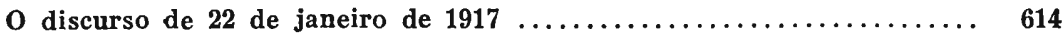

Mensagem presidencial de 11 de fevereiro de $1918 \ldots \ldots \ldots \ldots \ldots \ldots .614$

Conclusão da doutrina wilsoniana $\ldots \ldots \ldots \ldots \ldots \ldots \ldots \ldots \ldots \ldots \ldots \ldots \ldots \ldots \ldots, 615$

São as nações sujeitos de direito internacional? $\ldots \ldots \ldots \ldots \ldots \ldots \ldots 6.615$

Proteção às nacionalidades $\ldots \ldots \ldots \ldots \ldots \ldots \ldots \ldots \ldots \ldots \ldots \ldots \ldots \ldots \ldots \ldots, 6 \ldots \ldots$

Lição da história do direito internacional $\ldots \ldots \ldots \ldots \ldots \ldots \ldots \ldots \ldots .616$

O Império Britânico $\ldots \ldots \ldots \ldots \ldots \ldots \ldots \ldots \ldots \ldots \ldots \ldots \ldots, 617$ 
União pessoal $\ldots \ldots \ldots \ldots \ldots \ldots \ldots \ldots \ldots \ldots \ldots \ldots \ldots \ldots \ldots \ldots, \quad 617$

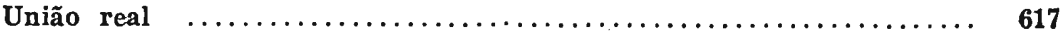

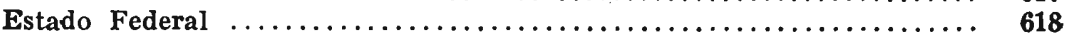

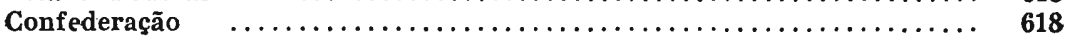

A opinião de Massimo Piloti $\ldots \ldots \ldots \ldots \ldots \ldots \ldots \ldots \ldots \ldots \ldots \ldots, 618$

A Santa Sé - Os Estados do Papa $\ldots \ldots \ldots \ldots \ldots \ldots \ldots \ldots \ldots \ldots \ldots, 620$

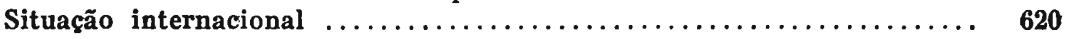

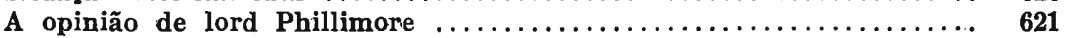

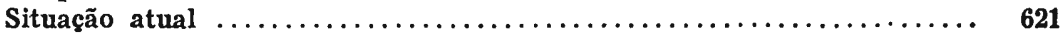

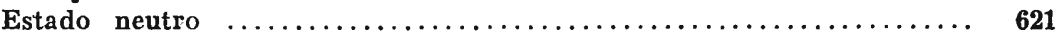

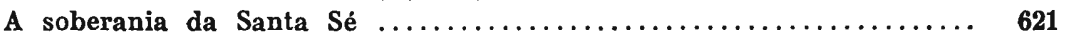

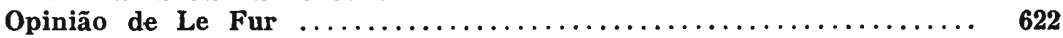

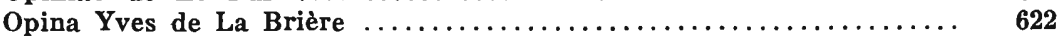

0 tratado de Latrão e o direito internacional privado ............6.622

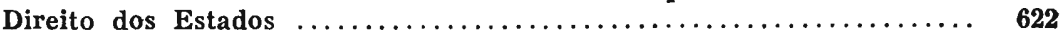

Igualdade, honras e Itítulos $\ldots \ldots \ldots \ldots \ldots \ldots \ldots \ldots \ldots \ldots \ldots \ldots \ldots \ldots \ldots, 6 \ldots \ldots$

Honras $\quad \ldots \ldots \ldots \ldots \ldots \ldots \ldots \ldots \ldots \ldots \ldots \ldots \ldots \ldots \ldots \ldots \ldots \ldots \ldots, \quad 623$

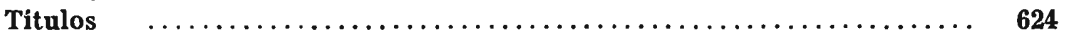

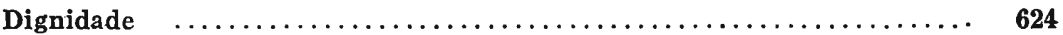

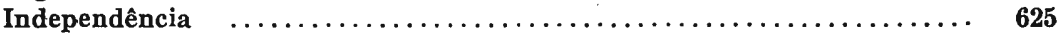

Deveres dos Estados $\ldots \ldots \ldots \ldots \ldots \ldots \ldots \ldots \ldots \ldots \ldots \ldots \ldots \ldots, \quad 625$

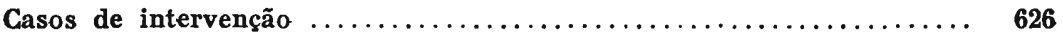

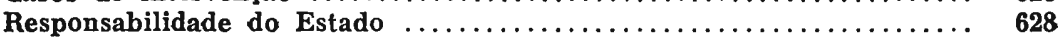

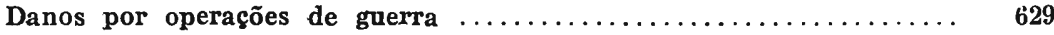




\title{
O ESTUDO MODERNO DO DIREITO INTERNACIONAL
}

\author{
"I suppose that methods have to vary always \\ with the teacher, and that no teacher can employ \\ the methods of others". (Prof. Hudson) (1)

Limitam-se, geralmente, os professores de Direito Internacional a ensinar principios consagrados e a defender os interesses dos poderosos; não concorrendo em nada para o progresso do ramo do Direito que ensinam. $O$ mestre honesto e conciencioso deve criticar o Direito Internacional existente, obrigar o aluno a refletir sobre seus principios fundamentais.

TRANSFORMAÇÃO

DO DIREITO IN-

TERNACIONAL (2)

A conflagração européia transformou a psicologia dos povos. E' necessário hoje, no mundo de após guerra, submeter todos os princípios a uma critica objetiva, reconstruir as ciências sociais, e portanto o Direito Internacional. Este variou, transformou-se radicalmente, e não sabemos mesmo quais as leis em vigor, os seus principios estão obsoletos, surgiram nova doutrinas e aspirações.

DIFICULDADES

NO ENSINO DO

DIREITO INTER-

NACIONAL

Numerosas são as dificuldades no ensino do Direito Internacional. Como veremos no decorrer do nosso curso, a noção de "soberania" transformou-se radicalmente. Não sabemos que importância ligar á organização internacional,

á Sociedade das Nações. Quanto ás "leis da guerra", verificou-sc que é impossivel levá-las a sério.

(1) Proceedings of the Fourth Conference of Teachers of Internacional Law and related subjects - (Oct. 10-17-929). nal -1928

(2) V. Rodrigo Octavio - A Renovação do Direito Internacio- 


\section{CONDIÇÕES DESFAVORAVEIS PARA O DESEN- VOLVIMENTO DO DIREITO INTER- NACIONAL}

Além do mais, si, no século XIX, a nota dominante entre os internacionalistas era o "pessimismo", após a grande guerra aumentaram extraordinariamente as "condições desfavoraveis" para o desenvolvimento do Direito das Gentes. Em primeiro lugar, ha

a "desconfiança geral" em relação aos principios de um Direito desrespeitado sistematicamente, cujos princípios se mostraram incapazes de contribuir para evitar-se a guerra ou mesmo para abrandar as práticas bélicas. Em segundo lugar, houve a desilusão tremenda da "Sociedade das Nações". Esta não conseguiu a universalização desejavel, ficando fora de seus quadros a América do Norte, desmoralizando-se a instituição completamente nos últimos tempos, tornando-se mesmo motivo de mofa.

CONDIÇõES FAVORAVEIS

No entretanto, nos últimos anos, começou-se a encarar a solução dos problemas mundiais com optimismo e confiança. Aumentou ultimamente, de maneira extraordinaria, o interesse pelo estudo do Direito Internacional. Basta lembrar que, na Inglaterra e nos Estados Unidos, dobrou o número de professores e alunos, e, do mesmo modo, reduplicaram as instituições usando o Direito das Gentes, amplificando-se o material para o seu estudo. Publicam-se atualmente numerosas revistas e jornais sobre o Direito das Gentes, e os diários tratam carinhosamente das questões em que estão em jogo os interesses da comunhão internacional.

Em 1929, existiam, na América do Norte, 91 cursos de Direito Internacional, para os alunos de altos estudos; 20 dados nas Faculdades de Direito, 71 nas "gratuated schools". (3)

Na grande República, o Direito Internacional é estudado coin muito carinho. Basta lembrar que, de 1914 até 1932, os professores da matéria se reuniram em 5 conferências tendo em vista a melhor maneira de ensinar o Direito das Gentes, e que a Universidade de Michigan consagra cursos especiais á Metodologia e á Pedagogia em Direito Internacional.

(3) Proceedings of the Fourth Conference of Teachers of International Law, pag. 239. 
Os estudos de Seminário, conforme ensina John B. Whitton, professor de Direito Internacional da Universidade de Princeton, (4) são feitos com muito cuidado.

Dedicam-se principalmente os seminários ás investigações, aos estudos aprofundados.

\section{TENDENCIAS DO DIREITO INTER- NACIONAL}

As tendências do Direito Internacional são hoje optimistas, dominando o desejo de "acabar com a guerra", organizando-se a "Justiça Internacional" Para isso aproveitam-se os juristas dos ensinamentos das outras ciências sociais - Geografia, Política Mundial, Finanças, Direito Financeiro Internacional, etc. E' hodiernamente fato consumado a "internacionalização de todas as ciências".

\section{COMO ENSINAR O DIREITO INTERNA- CIONAL}

que diversificar de país a país.
Disse muito bem o Prof. Hudson que os métodos de ensino devem variar de professor a professor. Acrescentarei que necessariamente os métodos têm

\section{NA AUSTRIA}

Ensina Verdross que, na Austria, existem o "Seminário" e o "Proseminário". Este, o Proseminário, ë mais simples e modesto nos seus fins, pois trata unicamente de aperfeiçoar os conhecimentos do aluno. O estudo do Seminário é muito mais sério e aprofundado

No Seminário ha a discussão e crítica de "Publicações Científiças" e de "Casos Internacionais". Além disso, a produção de "trabalhos originais". Por meio dele, trata-se de inculcar o "Espirito Científico" sobre assuntos concretos. O seminário significa uma nova orientação que Fichte caracterizou dizendo que sua finalidade "era formar" o espírito científico. Assim diz o artigo $10^{\circ}$ do estatuto que rege o seminário jurídico de Berlim:

"O seminário juridico tem por fim iniciar os estudantes no trabalho científico pessoal por meio de exercícios exegéticos, históricos e dogmáticos, e prepará-los para investigações científicas originais".

(4) Revue de Droit International, 1933, t. 12, VII ano, num. 4, out. nov. dez. 
Na Austria, os estudos de seminário não deram resultado, devido á falta de professores e de material, acrescendo que os alunos, distraidos pelas necessidades da vida, não podem se dedicar convenientemente aos estudos minuciosos e demorados, conforme o depoimento de Verdross. Realmente é de notar que um seminário não deve comportar mais de 20 alunos. O de Borchard é de 10 a 12.

\section{O SEMINARIO DE} KIEL

Para os estudos aprofundados de Seminário, faz-se mistér professores suficientes, material escolar adequado, e alunos dedicados e rigorosamente selecionados. Só assim se conseguem os resultados que Schucking obteve, segundo informou á "Conferência de Professores" de Direito Internacional:

"We thus often discuss in our seminar at Kiel questions which carry us late into the night" (5).

NA FRANÇA

Gilbert Gider, na 4.* Conferência dos Professores de Direito Internacional, explica a organização do ensino do Direito das Gentes na França. Lá existe a "Licence en Droit" correspondente ao bacharelado, obtida em 3 anos de estudos, e o Doutorado, em 2 anos adicionais. Na "licence en droit" o estudo do "Direito Internacional Privado é obrigatório e o do Direito Público Internacional, facultativo". No Doutorado, acontece o contrário.

Na Faculdade de Direito de Paris, existem 4 cátedras de Direito Internacional: 3 de Direito Internacional Público, 1 de Direito Internacional Privado. Ha mais 16 cadeiras de Direito das Gentes em cada uma das 16 faculdades oficiais da França. Aliado á Faculdade de Direito existe o "Instituto de Altos Estudos Internacionais", dedicado exclusivamente ao estudo do Direito Internacional.

Na célebre ESCOLA LIVRE DE CIENCIAS POLfTICAS, fundada em 1871, e mundialmente conhecida, estuda-se o DIREITO INTERNACIONAL em dois anos, na secção dedicada á Diplomacia. Como é sabido, esta escola prepara para várias carreiras. E' tão notavel que serviu de modelo á Escola de Ciências Políticas, fundada em Berlim.

(5) Proceedings of the Fourth Conference of Teachers of International Law and related subjects. (Held at Briarcliff Lodge, New York, October 10-17-1929. Washington-Carnegie Endowment for International Peace, 1930). 
METODOS DE ENSINO

Os métodos adotados são em regra, segundo GIDEL, "conferências e interrogatórios", pelo professor e pelos assistentes, e os Seminários. 0 fim principal destes, segundo GrDer, é pôr o estudante em contacto com as fontes, o material, e ensinar-lhe a estudar um assunto cientificamente.

NA AMERICA DO NORTE

Não podemos deixar de nos referir aos estudos de Seminário na grande república americana. Lá dedicam-se os estudiosos do Direito Internacional ás investigações metódicas tendentes a aumentar os limites dos conhecimentos humanos. Como muito bem salienta JoHN WhitTon (6) as perspectivas ácerca do futuro dos estudos de Direito Internacional são, na America do Norte, de molde a encorajar. 0 interesse pelas investigações internacionais desenvolveu-se de uma maneira consideravel. Este se aproveitou da aliança íntima com o movimento em favor da cooperação internacional, para a redução dos armamentos e supressão da guerra.

Conquanto numerosissimos sejam os Institutos, Fundações, Conferências, etc., consagrados ás questões internacionais (7), devemos salientar que os estudos aprofundados são muito mais importantes em matéria internacional na America do Norte do que em qualquer outro país (8).

CONCLUSAO
Vemos, pelo exposto, que o Direito Internacional deve ser ensinado como coroamento do curso jurídico. E esta

a conclusão da 4.a Conferência de Professores de Direito Internacional: "Instruction in International Law should be taken as late as possible, and only when a certain intellectual maturity and legal knowledge has been reached" (XV.a conclusão).

ENTRE N6S

rado". "O curso de Bacharelado foi organizado atendendo-se a que
Entre nós a lei Francisco Campos seguiu caminho diverso. Dividiu o curso juridico em "Bacharelado" e "Douto-
elado foi organizado atendendo-se a que

(6) Revue de Droit International, 1933, t. 12, VII ano, n. 4, out. nov. e dez.

(7) H'ARLEY, International Understanding: Agencies Educating for a New World, pag. 221 seg.

(8) Wright, Research in International Law since the War, p.9. 
ele se destina á finalidade de ordem puramente profissional, isto é, que o seu objetivo é a formação de práticos do Direito", diz o exMinistro. E... colocou o Direito Internacional Privado no Doutorado.

Rodrigo Octavio, o insigne jurisconsulto pátrio, salienta a surpresa causada no Brasil pelo decreto do Govêrno Provisório, n. 19.852, de 11 de abril (9), suprimindo do curso ordinário nas Escolas de Direito a cadeira de Direito Internacional Privado, relegando o seu ensino para o curso facultativo e puramente ornamental de Doutorado. Felizmente a Faculdade de Direito de São Paulo, pelo Decreto Federal n..$^{\circ}$ 24.102, de 11 de abril de 1934, transferida pelo Govêrno da República ao Estado de São Paulo, e incorporada á sua Universidade, criada pelo Decreto n. ${ }^{\circ} 6.283$, de 25 de janeiro de 1934, adotou, pelo decreto $n .^{\circ} 6.429$, de 9 de maio de 1934, que aprova o seu regulamento, uma nova seriação de matérias. O Direito Internacional Privado é ensinado hoje na 3.a Cadeira do $5^{\circ}$ ano do curso de Bacharelado, e o Direito Público Internacional, na 2.a Cadeira do 2..$^{\circ}$ ano do curso de Doutorado.

\section{COMO DEVEMOS ENSINAR O DI- REITO INTER- NACIONAL?}

As minhas opiniōes sobre a reforma de nosso ensino foram expostas no meu parecer " $O$ Problema Universitário" (10). Quanto ao estudo do Direito Internacional Público deve ser feito no "Doutorado", evidentemente. Pretende-

mos neste nosso curso lecionar a matéria, de acôrdo com a lei, em duas aulas semanais, uma teórica e outra prática, de investigação metódica, certo de que, como diz Berganza, o exercício é o que faz, em todas as artes, aos homens mestres (11).

Nas aulas teóricas, daremos, este ano, uma síntese dos princípios fundamentais do Direito Internacional em tempo de paz. Nas nossas investigações de Seminário, procuraremos aumentar os conhecimentos, e desenvolver o espírito crítico, buscando, em cooperação intelectual estreita com os alunos, atingir a verdade, discutindo e elaborando trabalhos originais.

Estas investigações constituem o fim supremo da Universidade no seu sentido mais elevado. Já dizia Flexner, que a universidade deve abrigar e formar pensadores, experimentadores e inventores,

(9) Dicionario de Direito Internacional Privado, 1933, pag. 369.

(10) Revista da Faculdade de Direito - Vol. XXV. 448.

(11) Antiguedades de España - MDCCXIX, t. $10^{\circ}$ p. 579, n. 
professores e estudantes que, sem responsabilidade de aplicação prática, exploram os fenômenos sociais e procuram compreendê-los (12).

Já vão longe os tempos em que os povos se queixavam das Universidades, e queriam que se fechasse a de Coimbra, por serem estudos prejudiciais ao Reyno, afim de que se evitassem letrados sobejos e os bachareis excusados no Reyno, e tantas demandas injustas que eles sustentavam, por terem de que viver. (13).

Não desconhecemos as dificuldades que fatalmente encontraremos no curso de doutorado. Um dos maiores obstáculos será para nós a falta de material. Outro estôrvo seria a escassez de tempo. Esta felizmente não é tão grande para nós. Um dos maiores erros das Universidades é esmagar professores e alunos capazes de investigações, sob o pêso de horários forçados, o que constitue uma verdadeira espoliação contra a sociedade, como salienta, com muita agudeza, OGG (14).

o sistema de se obrigar um notavel professor a ler e corrigir milhares de provas escritas é inconcebivel. Atualmente no nosso doutorado trabalharemos em cooperação, procurando mesmo, quando possivel, recorrer a auxílio de outros especialistas em ramos diferentes dos conhecimentos humanos. As Universidades estão maravilhosamente adaptadas para estas investigações originais. Apontaremos o exemplo da "Harvard Research in International Law". Realmente, numerosos problemas de Direito Internacional exigem os esforços combinados de juristas, economistas, químicos, historiadores, etc.

As nossas investigações terão fatalmente, de futuro, importância capital, concorrendo para a formação de professores competentes, para o esclarecimento da opinião pública, e para a formação de uma elite intelectual em nossa pátria.

Já na escolha dos estudantes que seguem este curso, selecionados cuidadosamente, ha uma esperança e progresso intelectual. E' necessário, para seguir um curso de Direito Internacional Público, um preparo preliminar de Direito Interno, História e outros numerosos conhecimentos aprofundados, além de maturidade mental.

Whitron salienta mesmo as vantagens dos estudos em país estrangeiro para os escolares de Direito Internacional, sobretudo para aqueles que o querem ensinar. Diz ele: "Estes estudos deveriam compreender, no mínimo, um ano em uma Universidade estrangeira

(12) Universities, American, English, German.

(13) Padre Jozé Pereira Bayão, Portugal cuidadoso e lastimado, Lisboa, 1737, páginas 36 e 43 .

(14) Research in the Humanistic and Social Sciences. 
dando cursos apropriados, por exemplo em uma das instituições admiraveis consagradas aos altos estudos internacionais, como os Institutos de Genebra, Hamburgo e Berlim.

Se o aluno não dispõe de tempo tão importante, deveria ao menos seguir durante um ou dois verões os cursos dados na "Academía de Direito Internacional de Haya". Isto já foi formalmente recomendado desde 1914 pela Associação Americana de Professores de Direito Internacional.

Existem nos Estados Unidos numerosas bolsas destinadas a esse fim. Consideremos que, para aperfeiçoamento da inteligência e ajuda para a solução dos graves problemas que hoje dividem os Estados e ameaçam a própria sorte da civilização, é necessário que o especialista em Direito Internacional conheça, não só as concepções juridicas dos outros povos, mas tambem suas tradições, costumes, maneiras de vêr, e problemas de toda sorte, e um tal conhecimento é impossivel sem viagens de estudos em países estrangeiros, e, mais ainda, sem neles se fazerem estadias mais ou menos longas (15).

\section{SUPERFICIALIDADE}

o Direito Internacional inspira-se nos precedentes históricos, e dai sua "superficialidade", pois estes são unicamente, em regra, a consagração da violência. Edificado por "juristas e diplomatas": sempre prontos a curvar a espinha diante dos poderosos e justificar os crimes dos triunfadores, distingue-se pelo seu "reacionismo" No nosso curso, exporemos uma "concepção popular, democrática", que contrapomos á concepção tradicional, "clássica, aristocrática e nacionalista", exposta, quasi sempre, nos cursos de "Direito Internacional Oficial".

As bases do Direito Internacional são as mais frageis que se possam imaginar. Ralston (16), o grande jurista americano, que, em 1922, fez para o "Direito Internacional Público" o mesmo trabalho de desentulho e reconstrução, que, em 1910, fez NoRman ANGEL para a "Economia Social Internacional" (17), salienta, em páginas vibrantes, o descrédito do próprio termo "Direito Internacional". Realmente, tal como é ensinado, esse pretenso Direito não tem nenhuma

(15) Revue de Droit Internacional, 1933, VII ano, t. 12, n. ${ }^{\circ}$, out. nov. e dez., pag. 596. Marquis).

(16) Le Droit International de la Démocratie (trad. Henry

(17) Ed. Lambert. 
fixidez e os seus princípios são proclamados para serem infringidos e levados em zombaria pelos Estados, parecendo uma criação no papel. Ensina-se sobre cada uma das matérias explicadas o que sobre ela pensam Grócio, Hall ou Oppenheim, lafayette ou Epitácio Pessoa, como se a opinião de um homem pudesse ser o Direito. Demais, não esqueçamos que mesmo o conservador Bonfiss-FAUcHILle manda desconfiar dos publicistas, "testemunhas dos sentimentos e dos usos das nações civilizadas", na frase de Lours RENAULT.

Infelizmente os intelectuais, por via de regra, servem os interesses dos poderosos, e traem a sua nobre missão (18). E a prostituição intelectual muito mais nociva e imensa que a prostituição física, fulminada em frases candentes por Barthelemy le Ligt (19).

D O G M A S se funda a soberania para negar a existência atual ou potencial de um poder superior ao seu? Como puderam os juristas acreditar em uma soberania ilimitada, em um Estado "todo-poderoso", acima de toda a lei moral?

"As leis da guerra" - eis outra farça. Não temos leis contra a guerra, e sim leis sobre ela. Não deveriamos legislar contra o assassinato e o roubo, mas sim, regulá-los.

REACIONISMO aprenderam que seus senhores não podiam cometer injustiça. Enquanto inauguravam o Direito das Gentes, suportavam:

(18) "Jamás ni en parte alguna se ha enganado tanto de buena o de mala fe - como en materias politicas; jamás ni en parte alguna se han desejado llevar los hombres tanto por las apariencias, como en derecho politico $y$ aun en el "derecho internacional"; jamás ni en parte alguna se han dicho tantas mentiras, hablado y escrito tanto sobre cálculos equivocados, como en esta esféra; jamás ni en parte alguna se ha jugado tanto con las apariencias, se ha deslumbrado tanto, se ha representado tanta comedia, como aqui". (Lurs Gumplovicz - Derecho Politico Filosofico - p. 77 - 78).

(19) Contre la Guerre Nouvelle. 
"La force du pouvoir temporel.

L'attribut de la dignité souveraine et de la majesté.

Dont naissent la crainte et le respect qu'on a des rois"

Não existe nenhuma potência intermediária entre o rei, 'o ungido do senhor, e a própria divindade. Por uma consequência natural esta idéia foi aplicada ao Estado (20).

o "Estado onipotente" e a "Sociedade das Nações", gigantescas imposturas, são secundadas pelo "clericalismo" os "grupos politicos e econômicos", a "imprensa venal e os intelectuais", a serviço do poder. Na escola, os professores ensinam a mocidade a reverenciar as instituições existentes, os dogmas respeitaveis, preparam a juventude para a escravidão.

\section{DEMOCRATIZAÇĀO DO DIREITO INTERNACIONAL}

çōes, até agora instruidas nova, livre de preconceitos, capaz de criar um Direito Internacional Democrático; justo, porque será util: quanto mais nos aproximamos das formas superiores da sociedade, o que é moralmente bom coincide, cada vez mais, com o que é praticamente util.

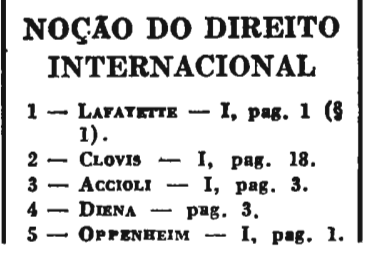

O Progresso do Direito Internacional depende do aperfeiçoamento da

E preciso portanto esclarecer 0 espírito dos povos, das modernas gerae mentiras, formar uma mentalidade

Devido ás divergências de escola, variam os autores no definir o direito Internacional. E o que salientava já o nosso eminente LAFAYETTE (21).

Para aqueles que aceitam a teoria etática, segundo a qual só os Estados são pessoas de Direito Internacional, alma humana.

(20) Ralston, - Le Droit Int. de la Démocratie.

(21) Direito Internacional, I, pag. 2 - A obra de LAfayeTtF, que citaremos frequentemente, é um dos trabalhos mais notaveis sobre a matéria. Publicado o seu livro Principios de Direito INTerNACIONAL, em 1902, declarou que fazia obra de direito positivo, baseando-se nas fontes mais autorizadas. Recorrendo repetidamente aos autores dos outros povos não desprezaremos os nacionais, fugindo ao mau vêzo de só reputar bom o que é escrito em lingua estranha... "Achaque fatal, e que só se pega nos portuguezes, desestimarem o proprio, por avaliar o peregrino" (Fr. ANTONIo DE Santa Maria, Orbe seraphico, Lisbôa - MDCCLXI). 


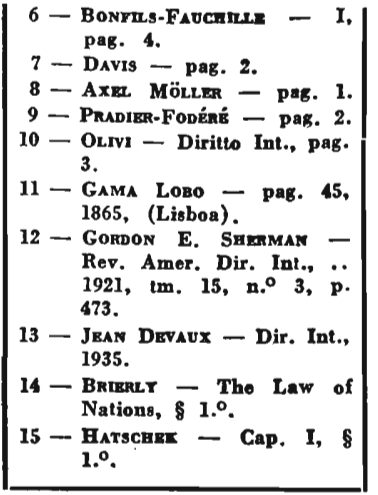

\section{DEFINIÇÃO DE} OPPENHEIM pode ele ser definido: corpo de regras costumeiras e convencionais consideradas legalmente obrigatórias pelos Estados civilizados, em suas relações reciprocas.
E a definição de OpPenhem, o saudoso professor da Universidade de Cambridge: "Law of nations or International Law (droit des Gens, Volker-

recht) is the name for the body of costumary and conventional rules which are considered legally binding by civilised states in they intercourse with each other" (22).

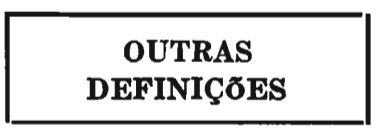
criticadas em si mesmas (23), como ensina SpIRopoulos o preclaro professor da Universidade de Salônica. Este grande mestre, o técnico admiravel de Direito Internacional, salienta o absurdo das criticas ás construções juridicas, que dependem quanto a seu conteudo da descrição do observador, e que são conceptos a priori, e, portanto, perfeitamente arbitrários. Esse subjectivismo é superado, na prática, pelo axioma jurídico fundamental : a expressão da convicção que sempre que em matéria jurídica se recorre a um concepto, é o que foi reconhecido pela opinião dominante que se deve adotar. $\mathbf{E}$ existe realmente arraigada na humanidade a idéia de que se deve seguir sempre a opinião da maioria - princípio objectivo majoritário.

(22) International Law - vol. I, pag. 1.

(23) Martinez Paz - Filosofia del derecho, p. 47. 


\section{PALAVRAS DE SPI- ROPOULOS}

Resumindo suas opiniões sobre o assunto, diz SpIRopoulos: "Conquanto toda a construção jurídica, do ponto de vista estrictamente abstracto, seja tão exata quanto qualquer outra, ha, entre as diferentes construções imaginaveis, uma construção privilegiada no sentido de ter por si a opinião dominante.

Esta diferença puramente exterior nos fornece o "princípio objectivo" permitindo superar o subjectivismo absoluto em matéria de construções juridicas. Este princípio da opinião juridica é o principio que permite que nos entendamos no dominio das construções juridicas, e sem o qual a ciência do Direito não poderia existir. E ainda este principio que nos dá a comum medida de apreciação do valor das soluções no domínio da aplicação do Direito (24).

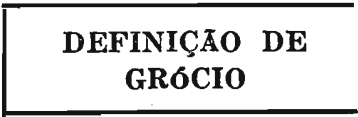

obliganti accepit” (De - § 14).
"International Law or as it is sometimes called, the "Law of Nations", may therefore be defined as that body of rules and limitations which sovereign States, of the civilized world agree to observe in their intercourse and relations with each other" (25).

\section{POLITIS}

Completamente diversa da definição de Oppenheim é a de Politis que diz que o Direito Internacional regula relaçōes de homens pertencentes a grupos políticos diferentes (26). Para ele o homem é pessoa de Direito Internacional, opinião que não podemos aceitar.

(24) SpIRopoulos - Droit Intern. p. 20.

(25) International Law, pag. 2.

(26) Novas tendências do Direito Internacional, p. $45 \ldots$ Le problème des limitations de la souveraineté. Cours A. D. I. Haye, t. 6, 1925 - I p. 7 . 
DEFINIÇAO DE UM NOTAVEL INTER-

NACIONALISTA BRASILEIRO

Hildebrando Accioly no seu recentissimo trabalho "TRATADO DE DIREITO INTERNACIONAL PÜBLICO" (1933) (27) diz que o Direito Internacional Público pode ser definido como sendo o conjunto de regras ou principios destinados a regular os direitos e deveres internacionais dos Estados, ou outros organismos análogos, dotados de tais direitos e deveres e dos indivíduos (I, p. 4).

\section{A DOUTRINA ETA-} TICA

Para nós Direito Internacional é o que regula as relações dos Estados entre si, como diz Clovis Bevilaqua (28). Direito Internacional é o conjunto de normas juridicas estabelecidas por mútuo consentimento dos Estados para regular suas relações recíprocas (29). Os Estados são, como veremos, as únicas pessoas internacionais. O Direito Internacional regula as relações recíprocas dos Estados com os outros Estados que com eles co-existem na comunhão internacional.

Somente as regras reguladoras das relações dos Estados entre si é que são de Direito Internacional (30).

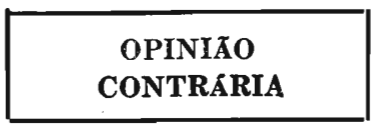

Muitos salientam, além de PoLITIs, o crescimento da posição do individuo no plano internacional e argumentam vivamente para provar que não só os Estados são pessoas internacionais. Veja-se: SpIropoulos - L'individu et le Droit International (Cours-H'aya, t. 30); A. Mandelstans R. D. Int., (La Pradelle 1930); Jean Devaux - Quelques réflexions sur les problèmes essentiels de la qualité de sujet de Dr. Int. (extrait des Mélanges Patxot, Barcelone, 1931, pag. 99).

DEFINIÇĀO DE DIENA

Não podemos deixar de nos referir á definição de Drena: "El conjunto de normas que determinam los derechos $y$ deberes recíprocos de los Estados y de los entes que formam parte de communidad juridica internacional" (31).

(27) Direito Internacional - t. I., p. 18, $\$ 2 .^{\circ}$, n. 1.

(28) Direito Internacional - t. I, p. 18, $82^{\circ}$, n. 1.

(29) NIEMEYER - D. Int. p. 16.

(30) AXEL Möllen - p. 1, 3.

(31) Der. Intern. Pub. p. 4. 
Acha Diena que, além dos Estados, seria grave erro excluir a possibilidade de que em diversas condições históricas tambem outros entes, além dos Estados, possam reputar-se sujeitos de Direito Internacional. Acrescenta que os principais sujeitos deste Direito são os Estados e que se ocupará das relações entre estes, objecto do seu trabalho. Ora, parece-me, ninguem nega a possibilidade de outros entes se tornarem, em diversas condições históricas, sujeitos de Direito Internacional, o que se contesta é que o Direito Internacional atualmente regule outras relações que não as que se estabelecem entre os Estados.

o Direito Internacional pode transformar-se, transformar-se-á fatalmente, e são precisamente as perspectivas de suas futuras transformações que tornam, ainda mais, empolgante e dificil o seu estudo.

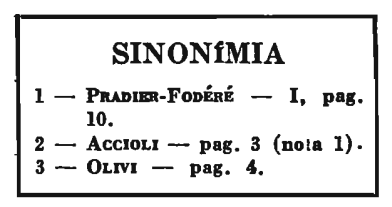
primeiro usou da expressão "Direito Internacional". BENTHAM inventou o termo "Direito Internacional" (International Law), em 1790.

Na edição de 1823, de seu livro "Morals and Legislation (V. II, pag. 262), diz: "Quanto á expressão internacional teve suas raizes na lingua deste trabalho, ou das primeiras obras da tradução em francez de Dumont (Lawrence S. Wheaton, p. 114)".

Nys (34) explica que essas expressōes são sinônimas, mas que alguns autores tentaram distinguí-las. Para eles, o Direito das Gentes ensinaria a regra que deveria ser observada, o Direito Internacional, a regra observada na realidade (DENis C. HERoN).

Mas essa distinção não foi adotada, como ensinou Jfan Devaux, em sua recentissima obra sobre a materia (1935).

E' bom advertir que as expressões Direito Internacional e Direito das Gentes são sinônimas (LAFayette, p. 2, Despagnet, p. 41, BonFILS-FAUChille, p. 5, n. 3).

MARcel Moye, o insigne professor de Montpellier, denomina o seu trabalho - Droit des Gens Moderne. No Brasil, como ensina Crovis Bevilaqua, tem-se usado indistintamente das duas expressões. O decreto de 25 de novembro de 1826, que nomeou o Comen-

(32) Fusinato - Dei feziale e del diritto feziale.

(33) Gondon E. Sherman - Jus Gentium and International Law-American Journal.

(34) Droit Int. p. 61. 
dador Blancardi plenipotenciário para o CONGRESSO DO PANAMA', falou de princípios luminosos do Direito das Gentes e Público Universal.

A lei de 11 de agosto de 1827, criando os cursos jurídicos, em São Paulo e Olinda, instituiu uma cadeira de Direito Natural Público, análise da Constituição do Império, Direito das Gentes e Diplomacia Essas palavras se reproduzem nos estatutos aprovados pelo decreto de 7 de novembro de 1831. Segundo os estatutos de 1854 (decreto n. 1.386 , de 28 de abril) na $1 .^{a}$ cadeira do $2 .^{\circ}$ ano das Faculdades de Direito devia ensinar-se, além de outras matérias, o Direito das Gentes. O decreto de 19 de abril de 1879 falou em Direito das Gentes e da mesma denominação se serve o decreto $n .^{\circ} 1.232-\mathrm{F}$, de 2 de janeiro de 1891. A lei n.o 314, de 30 de outubro de 1895, o Código do Ensino e o dec. 11.530 usam da expressão Direito Internacional. O decreto 16.782-A, de 13 de janeiro de 1926, fala em Direito Público Internacional. Atualmente, modificou-se a seriação de matérias do curso jurídico, e o Direito Público Internacional é ensinado não no 3..$^{\circ}$ ano do curso do Bacharelado, e o Direito Privado Internacional no $2 .^{\circ}$ ano, 2. ${ }^{2}$ secção do Curso de Doutorado (decreto 19.852, de 11 de abril de 1931), como determinava a reforma Francisco Campos, mas sim no $2 .^{\circ}$ ano do Doutorado, tendo o Direito Privado Internacional passado a ser lecionado no $5^{\circ}$ ano do curso de Bacharelado.

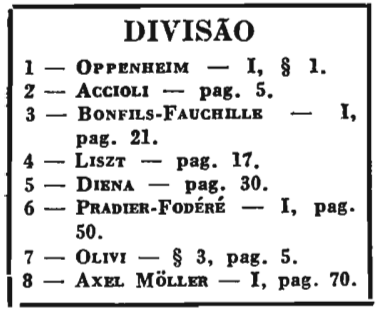

referia-se ao necessário e voluntário (L. II. ${ }^{\circ}$ cap. 12).

A parte das regras costumeiras e convencionais, consideradas legalmente obrigatórias, respeitadas em todos os paises civilizados sem excepção, eis o que se denomina Direito Internacional Universal. Exemplo: $O$ Direito de Legação. A parte dessas regras obrigatórias para um grande número de Estados, incluindo potências, constitue o Direito Internacional Geral, que tende a tornar-se Universal (35). Exemplo: O Pacto da Sociedade das Nações.

(35) V. Verdross - Cours, 30, pag. 297. 
A parte dessas regras, finalmente, obrigatórias somente para dois ou mais Estados, é o que se chama Direito Internacional Particular (36). E' essa a divisão da matéria adotada por OPPENNEIM.

Bourquin (37) divide o Direito Internacional em comum e particular. Refere-se tambem ás regras particulares que se apresentam como regionais, que não aspiram a se tornar gerais, mas sim se superpõem ou suprem o Direito Comum. Ha, entretanto, regras particulares que procuram universalizar-se, como o pacto BriandKellog.

O Direito Internacional pode dividir-se, segundo alguns (38), em Direito Internacional em tempo de paz e Direito Internacional em tempo de guerra. O Direito Internacional da guerra determina os direitos e deveres dos Estados beligerantes e dos neutros, que existem pelo fato, de se encontrarem dois ou mais Estados em situação de guerra. O Direito Internacional da paz regula as relações de ordem pacifica quer tenham lugar em tempo de paz ou de guerra.

Efetivamente, como observa o sábio internacionalista DiENa, a guerra não suprime a aplicabilidade das normas de Direito Internacional de paz nas relações entre os Estados que não se encontram entre si em situação de hostilidade, e mesmo entre os Estados beligerantes, algumas dessas normas podem ser aplicadas durante o curso da guerra, contanto que não tenham nenhuma conexão com as relações de ordem bélica (39).

Outros não admitem esta divisão da matéria. Afirmam que a guerra já não é uma instituição jurídica, e sendo hoje um ato universalmente condenado, a divisão não pode permanecer.

Esta divisão foi formulada por Grócıo e aceita por numerosos escritores que se lhe seguiram (40).

Atualmente as relações de proporção entre os dois direitos variaram. A princípio o Direito Internacional em tempo de guerra é que era importante, e o Direito Internacional da Paz não ocupava tanto a atenção dos escritores. Hoje, ao contrário, vê-se o Direito da Paz aumentar cada vez mais de importância e estensão, tornar-se o sistema normal das relações entre os Estados (41).

(36) Alguns não consideram o D. I. Particular como sendo $D$. I. (Cf. Hershey, p. 1).

(37) Cours Ac. D. Int., La Haye, vol. 35, pag. 6 - Alguns se referem ao D. I. europeu, americano, asiático, africano e até australiano (Bonfils-Fauchille - p. 34-7).

(38) A. Cavaglieri - Cours - 26, pag. 315.

(39) Axel MölleR - I., p. 71.

(40) OLIvi - p. 8.

(41) AXEL MöLlen - I, p. 70. 
Os autores que negam a existência do Direito da guerra argumentam que ela é um estado de anarquia entre Estados, uma relação de violência, impossivel de ser regulada pelo Direito, que a guerra é incompativel com ele. Essa doutrina não está de acôrdo com a realidade. Conquanto seja desejavel se acabar com a guerra, ela é, no momento atual, uma triste realidade regulada pelo Direito Internacional, uma instituição perfeitamente legal, em virtude da vontade dos Estados, como se deduz dos costumes e das convenções internacionais (42). Dividem, ainda, os autores o Direito Internacional ora em material e formal, ora em declarativo e perceptivo, etc. (AXEL MöLler - I, p. 71).

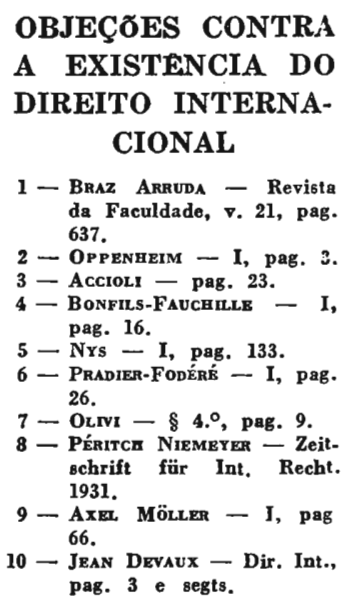

Muitos autores têm negado a existência do Direito Internacional ou, pelo menos, a sua autoridade efetiva. Diversas objeções têm sido feitas contra a sua existência, sendo as seguintes as mais importantes: falta de uma lei internacional, de Tribunal Internacional e força encarregada de o fazer respeitar. Essas objeções não procedem como demonstrei longamente no meu trabalho "CONCILIA-SE A EXISTENCIA DO DIREITO INERNACIONAL COM A FALTA DA COAÇÃO?" (43).

\section{A PRIMEIRA OB- JEÇĀO}

A' primeira objeção responde-se com Bonfils, Cruchaga e outros, que não é a mesma coisa lei e Direito. Póde não existir uma lei, e existir um

Direito Internacional. A lei nada mais é do que a tradução ou transcrição do Direito, é o Direito preexistente que adquire uma forma oficial. Todos os Códigos nasceram depois do funcionamento de regras de Direito. Poderá ser mais debil o Direito que não é

(42) Revista da Faculdade - Vol. 21, 1913, p. 637.

(43) Revista da Faculdade - vol. 21, 1913, p. 637. 
consagrado oficialmente em lei, mas não quer isto dizer que não exista, não tenha autoridade efetiva, como observa Phillimore. Não será tão perfeito, tão claro, tão preciso como o Direito Interno, e isso reconhecem Savigny (1814), LAFAYETTE e outros (44), mas é um verdadeiro Direito. Dentro da comunhão nacional, dizem os negadores do Direito das Gentes, os costumes com o tempo chegam a ser consagrados em lei, ha uma autoridade que promulga os Codigos: mas, quem legisla, quem dá forma aos costumes na sociedade dos Estados?

Realmente, o DIREITO INTERNACIONAL é, na sua maior parte, costumeiro (45), mas, ao lado dele, no sec. XIX, surge o DIREITO DAS GENTES CONVENCIONAL, com uma importância extraordinária. Demais, dentro em pouco, os Estados organizados terão como órgãos da SOCIEDADE MUNDIAL os poderes legislativo, executivo e judiciário (46).

Por enquanto, os Estados não têm nenhum poder uns sobre os outros, sendo o DIREITO INTERNACIONAL um direito entre os Estados (between) e não sobre os Estados (above). Os Estados submetem-se ás regras do Direito Internacional pelo consentimento comum.

SEGUNDA OBJEÇAO
Por não haver Tribunal não se segue que não haja Direito. Demais ha TRIBUNAIS INTERNACIONAIS. Lem-

bremos somente o TRIBUNAL PERMANENTE DE JUSTIÇA INTERNACIONAL, criado em virtude do Pacto da Liga das Nações (art. 14). Além disso, como salienta LAfayetTe (I, § 14), não é caracteristico do Direito Positivo que ele emane de um poder superior; nem tão pouco é uma necessidade para que ele se considere tal a existência de um poder organizado para aplicá-lo e torná-lo efetivo.

(44) Esse capitulo de Savigny - Traité de Droit Romain, trad. de Ch. Ghenoux (1855), é muito interessante. Salienta o grande jurisconsulto que o Direito Internacional baseia-se em uma comunhão de idéias, fundada em relação de origem ou relações religiosas. Dai o Direito Internacional que se formou entre as naçôes cristấs da Europa, o antigo Jus feciale dos romanos. SAvigny nega contudo que o Direito Internacional seja um Direito Positivo. LAFayetre, pelo contrário, o considera, mais justamente, como tal (I, § 14).

(45) LafayetTe - VI - (pag. anterior).

(46) V. Verdross - Cours 30, pags. 309 e segts. 
IMPORTANAIA DAS OBJEÇÕES CONTRA

A EXISTENCIA DO DIREITO INTERNACIONAL
Essas questões são somente teóricas, pois a prática nunca se recusou a confessar a autoridade do Direito das Gentes. Na prática internacional, os Estados sempre reconheceram a sua forca, a obrigatoriedade de seus principios, expressa ou tacitamente (47).

O govêrno inglês respondia, em 1763, ao govêrno prussiano: "O Direito das Gentes é fundado na justiça, na equidade, na conveniência e na razão das coisas e confirmado por prolongado uso".

Veja-se tambem em Frore (48) e Martens (49) a nota dirigida pela Rússia ás potências aliadas sobre as atrocidades praticadas pelos turcos na Sérvia.

\section{OS CONGRESSOS}

dec. de Aix La Chapelle (15 de Novembro de 1818) os contratantes se obrigaram a nunca se separarem dos principios do Direito das Gentes.

Citariamos ainda: O TRATADO DE PARIS DE 1856, e celebrado entre a França, os Estados Unidos e a Inglaterra, 18 de Maio de 1871 (Caso do Alabama), e o de 7 de Março de 1831, entre o Chile e os Estados Unidos. Entre outros, reconheceram a obrigatoriedade do Direito Internacional o Congresso de Vienna (18141815), de Paris (1856), as conferências de Londres e Washington (1871), os Congressos de Berlim (1878) e o Preâmbulo do Pacto da Liga das Nações (1919).

AINDA MAIS

Ainda mais, não só os Estados reconhecem a obrigatoriedade dos principios: do Direito Internacional, como ainda fazem os seus Tribunais civis e criminais, os seus funcionários e os seus súditos respeitarem as suas regras (50).

(47) LafayetTe - $\$ 14$; Bynkerschoek F. L. - cap. 19; SavigNy, I - cap. $2 \S 11$ - t. V.

(48) T. $10^{\circ}$ - p. 138.

(49) Recueil des Traités conclus par la Russie avec les Puissances étrangéres, t. I, p. 178.

(50) Mesmo nos Estados em que o D. I. não faz parte do D. Interno, como na Dinamarca, os tribunais nacionais têm que interpretar e aplicar tratados e outras regras de D. das Gentes. Dai a necessidade dos juizes conhecerem o D. I. que não póde ser considerado mera lei estrangeira (A. Möller, p. 8 - STrupp, I, p. 25). 


\section{O DIREITO INTERNACIONAL E A OPINIAO PÚBLICA MUNDIAL}

Quando um Estado viola os princípios do Direito das Gentes, a opinião pública mundial estigmatiza o seu procedimento, como se fosse violação de uma lei pura e simples. E sendo o Direito Internacional baseado no consentitimento comum dos membros da comunhão internacional, vê-se que ele é um direito obrigatório como qualquer outro.

\section{VIOLAÇб̃ES}

Os princípios de Direito Internacional são violados frequentemente (51), mas os Estados que os violam são os primeiros a justificar o seu procedimento lançando mão das próprias regras do Direito das Gentes. Nunca se viu um povo proclamar que violou concientemente as regras do Direito Internacional. Pelo contrário, procuram sempre os Estados que o violam, interpretá-lo, afirmando que se submeteram aos seus princípios. Demais, toda violação do Direito Internacional é fatal ao Estado que a pratica (52).

\section{S I N T E S E}

Resumindo: as objeções que, desde Hobbes e Puffendorff até Austin, se fazem contra a existência do Direito Internacional não resistem a um exame atento. Pouco importa que o Direito Internacional seja na sua maior parte costumeiro, pois nunca existiu um povo que tivesse unicamente direito escrito (PHILLIMORE - OPPENHEIM).

Por não existir um corpo de leis internacionais, por não haver Tribunal Internacional, não é que o Direito das Gentes deixaria de existir. Enquanto houver relações de Estado a Estado, haverá tambem um Direito que as reja juridicamente.

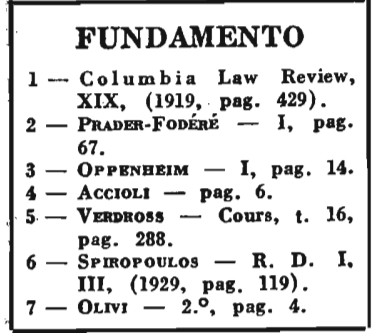

(51) LAFAYETTE, VII.

(52) Já se afirmou que o sentimento da justiça é o órgão do Direito Internacional; a história seu tribunal e que a sorte pune aquele que o viola (Cf. Heffter, 3).
Numerosas são as doutrinas sobre o fundamento do Direito Internacional. Vejamos em primeiro lugar a doutrina da CONVICÇÃO JURfDICA de KraBBE e Duguit - vulgarizada por Politis. Para esta doutrina o Direito Internacional existe por que os homens estão convencidos da sua existência e tambem da obrigatoriedade de suas normas. Dugurt, na sua monumental obra, diz 
que uma norma é obrigatória quando em um momento determinado é ela considerada tal. E' o mesmo que dizer que si neste grupo a norma é violada, é desrespeitada, pela maioria do povo, a massa dos espiritos acha que ela não é mais obrigatória, deixa de existir. A norma jurídica baseia-se, portanto, na opinião dominante. Consulte-se a respeito o TRATADO DE DIREITO CONSTITUCIONAL, edição de 1921, pag. 65. Esta é a doutrina da convicção jurídica: quando o espirito público, a maioria do povo acha que uma regra é obrigatória esta torna-se uma norma jurídica. Três são, portanto, para Duguit, os elementos da norma juridica:

$\left.10^{\circ}\right)$ convicção comum da obrigatoriedade da norma;

2. ${ }^{\circ}$ convicção de que é necessário que esta norma exista para manutenção da ordem social;

$3 .^{\circ)}$ que seja conforme ao espírito público que esta norma seja sancionada.

Quando existem estas três condições a norma é jurídica. Dugurt faz aplicação da teoria ao Direito Internacional em seu tratado: para que exista Direito Internacional é preciso que exista uma conciência internacional.

Existe uma norma juridica internacional quando a conciência internacional acha que esta regra de Direito deve ser respeitada, que é justo, que é vantajoso, que é necessário que a norma seja respeitada para manutenção da solidariedade internacional.

Quando esta conciência jurídica existe, quando ha a convicção da existência de uma norma jurídica, quando existe a convicção arraigada de que esta norma deve ser respeitada, que é obrigatória, esta norma é de Direito Internacional (obra cit. p. 55) (53).

SERÁ O DIREITO NATURAL O FUN. DAMENTO?

Muitos sustentam que o Direito Internacional Público se funda no Direito Natural. Realmente quando se formou o Direito Internacional acreditavam muitos na existência de um Direito Natural. Mas quando se trata de saber o que seja Direito Natural ai começam as dúvidas, não se tendo conseguido até hoje conceituar esta miragem juridica (54).

Admitamos, por hipótese, que o Direito Natural seja uma parte determinada da moral, funde-se na moral. Perguntamos nós a ra-

(53) Brierly - Cours - 23, pags. 236 e segts.

(54) O D. Natural não existe, já ensina Gumplowicz (Der Polit. Filos, p. 80). 
zão da obrigatoriedade do Direito Natural e responderão os adeptos do Direito Internacional Natural que o fundamento último do Direito Internacional é a moral. Mas, pergunto eu, qual o fundamento da moral? Talvez seja, em última análise, a teoria deles redutivel á convicção juridica.

\section{A DOUTRINA DA AUTO-LIMITAÇÃO}

Vejamos agora a célebre doutrina da auto-limitação de Jellineck. Parece-nos que essa doutrina não é moderna. Vem do Direito Romano. Por ela o Estado soberano não pode estar limitado pelo Direito. Não tem nenhum poder acima de sí. Se a soberanía é um poder ilimitado, incontrastavel de querer, o Estado não pode estar sujeito a nenhuma lei, não tem limites na sua ação. Esta é a primeira parte da doutrina de JeLLINEck. Mas, o Estado que tem essa soberania ilimitada, pode auto-limitar-se e auto-limitando a sua soberania submete-se voluntariamente ás normas jurídicas. Assim, fica o Estado vinculado á norma jurídica. Perguntam críticos e filósofos, entre os quais Nippold: por que é que o Estado se submete ao Direito que ele mesmo cria? Por que auto-limita o Estado os seus poderes? Responde Nippord: o Estado tem a convicção de que deve se ligar a uma norma, de que deve se submeter ao princípio que cria, ao Direito que ele próprio criou. Em última análise, pois, chegamos á doutrina da convicção jurídica. Citemos palavras do próprio JELLINECK :

“Toda tarefa da Filosofia do Direito concentra-se na questão de saber porque a vontade se deve considerar como ligada. Seja que se aceite a ordem divina, com a escola teolỏgica, seja que se aceite a lei da natureza humana, com a escola naturalista, seja emfim que se considere o contrato, com a escola do Direito Natural, como fonte da ordem jurídica, sempre trata-se de explicar este enigmático fenômeno psicológico que consiste em saber-se a vontade suscetivel de ser obrigada a sentir-se obrigada na realidade. Quando KANT queria fechar a discussão sobre o motivo da força obrigatória dos Tratados pela afirmação, que declara a obrigação contratual como sendo um imperativo categórico, tocou na verdade, pois a última base psicológica de uma obrigação não pode se encontrar senão no fato de se ter diretamente conciência de se ser obrigado. 0 pretendido imperativo categórico não indica senão o fato de uma análise psicológica ulterior da conciência de uma obrigação não ser posśivel" 
Ora, quando JeLrineck diz que o Estado auto-limita a sua soberania, e se submete ao princípio por ele mesmo criado, é porque está convencido de que deve se submeter ao direito que ele mesmo criou.

Os autores da teoria da auto-limitação distinguem entre um fundamento formal, ou jurídico, e um fundamento filosófico sociológico do Direito das Gentes. Quando falam de uma vontade ligando-se a si própria, querem simplesmente dizer que se está ligado á vontade uma vez manifestada (fundamento formal). Por que? Porque a vontade se sente ligada (fundamento material). Chegamos pois á doutrina da convicção jurídica.

\section{OUTRAS} DOUTRINAS

Wenzel diz que o Direito é sempre direito do Estado, que o Estado é que criou o Direito, e que o Direito Internacional obriga, em virtude do Direito Interno. E' a doutrina da delegação. Toda norma de Direito Internacional está subordinada a uma norma de Direito Interno. E' o sistema do império, da primazia do Direito Interno. O Direito Internacional nada mais é do que uma ramificação do Direito Interno, na ordem internacional, sua obrigatoriedade deriva do Direito Interno. Assim se um chefe do executivo de um Estado celebra um tratado internacional é porque tem poderes pelo Direito Interno. Esse tratado obriga ao Estado, em virtude do poder que tinha o chefe do executivo para obrigar o seu Estado. O Direito Internacional existe porque foi criado pelo Estado, e como todo Direito é Direito do Estado, o Direito Internacional obriga em virtude do Direito do Estado. As normas do Direito Internacional são uma delegação de normas do Direito Interno. O Direito Internacional nada mais é, portanto, que um prolongamento do Direito Interno na ordem internacional.

Existe ainda uma outra doutrina sobre o fundamento do Direito das Gentes, a da vontade comum, de Triepel. Não existe para este autor uma vontade de Estado, mas sim uma vontade comum dos Estados. Um grande número de Estados resolve se submeter a certas normas, e estas se tornam obrigatórias. Os Estados se submetem a esta vontade comum, aos princípios criados por eles, porque têm a conciência, porque têm a conviç̧ão de que devem se submeter a estes princípios criados pela vontade comum. Eis-nos novamente chegados á doutrina da CONVICÇÃO JURIDICA. 


\section{A REGRA FUNDA- MENTAL SUPREMA FUNDAMENTO DO DIREITO INTER- NACIONAL}

KeLsen, o Einstein do Direito, diz que toda norma juridica deriva de uma norma superior. Esta depende de uma outra norma, e se todas as normas jurídicas dependem de outras normas superiores, podemos conceber o Direito como uma formidavel pirâmide. Todo Direito depende, enfim, de uma norma última da qual todas as outras normas derivam: - é a norma suprema. Esta norma superior, esta norma suprema, esta norma última, da qual derivam todas as normas juridicas, é denominada norma hipotética ou norma fundamental suprema.

Verdross, seguindo a KeLSkr. diz que esta norma fundamental suprema é a regra PACTA SUNT SERVANDA. A esta teoria poderiamos fazer varias objeções. O Direito das Coisas, por exemplo, não se baseia nessa regra PACTA SUNT SERVANDA. Diz muito bem Diena que não se póde fundamentar todo o Direito Internacional neste princípio, que se refere unicamente a uma de suas partes. Pode-se, realmente, discutir se tal principio pode considerar-se como um axioma e nem mesmo é caracteristico do Direito das Gentes, mas vale em geral, para a matéria de obrigações convencionais em qualquer ramo do Direito.

Para Verdross toda a regra convencional supõe o princípio PACTA SUNT SERVANDA. Daí a pirâmide juridica (Cours, XXX, 290). E' o sistema unitário do Direito, tendo por base o Direito Internacional (id. p. 292). Além disso, para aqueles que sustentam que o costume não é um contrato tacitamente feito. entre Estados, tambem não se baseia o costume na famigerada regra PACTA SUNT SERVANDA.

Que o Direito costumeiro é convenção tácita sustentaram Grócro, Prol. \& 3. ${ }^{\circ}$, Rachel, De Jur. Nat. et Gent., Bynkershovex, Triepel, Anzilotti, Cavaglieri; contra, estão Vitoria (De Indis), Oppenheim, Westlake, Virscher (Cours, 6-925, I, p. 361), Fauchille, (I, pag. 43) e G. Balladore Pallieri (Riv. X-1928, pag. 338), o eminente professor de Messina, que não exigem para a criação de uma regra universal adesão de todos os Estados. E é esta a teoria que está de acôrdo com a prática internacional.

VERDRoss responde a essas objeções que elas são feitas porque nem todos compreendem a sua concepção. A concepção da regra PACTA SUNT SERVANDA é, para ele, original, diferente de todas as outras, portanto, aqueles que se baseiam na accepção vulgar da regra não têm razão. E' preciso para combatê-lo saber o que ele quer dizer... 
E, depois, não explica convenientemente o conceito que tem desta famosissima regra - PACTA SUNT SERVANDA (55).

\begin{tabular}{c} 
FUNDAMENTO DO \\
DIREITO INTERNA- \\
CIONAL \\
Westuary - Dir. Int. (trad. \\
Lapradelle - 1924, 7, 9, 316). \\
\hline
\end{tabular}
ree-nos, perguntar porque nos submetemos ás normas juridicas. Basta-nos verificar que ha certas normas obrigatórias ás quais estamos convencidos de que nos devemos submeter. O Direito, explica OppenheIm, baseia-se no consentimento comum. Si o Direito é um corpo de regras para a conduta humana dentro de uma comunhão social, que por consentimento comum dessa comunhão pode ser sancionado por um poder superior, o consentimento comum é a base de toda a lei, o fundamento do Direito.

\section{CARACTERISTICOS DAS REGRAS OU NORMAS JURI- DICAS}

As regras morais aplicam-se á conciência, e á conciência unicamente. Um ato de caridade perderia todo o mérito se não fosse perfeitamente livre. Ao contrário, uma regra juridica carateriza-se por poder, em caso de necessidade, ser sancionada por uma fôrça exterior. A sanção não é pois indispensavel á existência do Direito, a coação não é portanto a sua caracteristica.

Vejamos a formação das leis.

Pelo consentimento comum, na Inglaterra o Parlamento é competente para legislar. Mas, por que tem força obrigatória uma lei emanada do Parlamento inglês? Porque, atrás dele, está o consenti-

(55) Os alemães como salienta Simons (Cours - Ac. Dr. Int. La Haye, XV, pg. 475), têm um pendor imoderado pelos sistemas, doença mental pouco conhecida na Inglaterra. Realmente, o racionalismo é bom engenheiro, mas deve prevenir sua máquina com uma válvula de segurança para que o irracional possa escapar, ele que é a força motora das coisas humanas. De modo contrário o irracional torna-se um verdadeiro diabo e fará saltar todo o edifício filosófico. Diz Simons que em sua luta contra a natureza das coisas os setários de KeLsen fazem lembrar os versos do poeta latino: NATURAM EXPELLAS FURCA TAMEN USQUE RECURRET. 
mento comum do povo inglês, expresso por meio do Direito não escrito.

Dai poderemos concluir com OPPENHeIM: "Thus the very important fact comes to light that all statute or written law is based on unwritten law in so far as the power of Parliament to make statute law is given to Parliament by unwritten law". E' pelo consentimento comum do povo inglês que o Parlamento tem a faculdade de fazer leis, que podem ser sancionadas por um poder exterior. $\mathrm{E}$ ainda ao lado das leis feitas pelo Parlamento, existem, e, constantemente, dia a dia, crescem e aumentam, outras normas costumeiras ou não escritas, reconhecidas quotidianamente pelos Tribunais.

\section{O CONSFNTIMEN- TO COMUM}

Mas, que significa consentimento comum? Si significasse que todo e qualquer membro de uma sociedade devesse dar esse consentimento comum a

todo o momento, si significasse que, em qualquer momento, qualquer membro de uma comunhão social pudesse negar, ou tivesse de dar o seu consentimento para haver lei, esse consentimento comum nunca existiria. Os individuos, membros de uma sociedade, nascem nela, nela crescem, desenvolvem a sua atividade, e nela morrem dando lugar a outros.

A sociedade, a comunhão social, conserva-se inalterada, conquanto uma mudança continua se opere nos seus membros.

O consentimento comum (common consent), significa, portanto, o consentimento, expresso ou tácito, de uma maioria tão esmagadora, que os que dissentem desaparecem, por assim dizer, completamente. Saber si ha, em determinado caso, consentimento comum é um fato de prática, e não de teoria. E' um caso de observação e apreciação, como a conhecida pergunta: quantos grãos fazem um monte? (56).

As regras legais que passam dos antepassados aos descendentes com força obrigatória são leis somente enquanto estes, por consentimento comum, as observam.

Novas regras só se tornam normas juridicas si conseguem o consentimento comum dos que compõem a sociedade em um dado momento (MAINe - Ancient Law - pag. 7).

E' por isso que o costume está no começo de toda lei, escrita ou não escrita (57).

(56) How many grains make a heap?

(57) Lafayette, $\S 5 .^{\circ}$, pag. 8 (nota). 
O que dissemos ácerca da lei pura e simples, aplica-se ao Direito Internacional. Contudo a comunhão pela qual é dado esse consentimento, não consiste em individuos, mas, sim, em Estados. $\mathrm{Na}$ sociedade dos indivíduos existe uma mudança constante nos seus membros, ao passo que na sociedade dos Estados essas mudanças são muito mais raras. De vez em quando, na Família das Naçôes, surge um membro ou desaparece outro.

Nela, os novos membros são recebidos simplesmente, por consentimento expresso ou tácito dos Estados antigos. E' pois necessário estudar o que vem a ser esse consentimento comum na Familia das Nações.

\section{CONSENTIMENTO COMUM NA FA- MILIA DAS NAÇŌES}

As regras costumeiras do Direito Internacional apareceram por consentimento comum dos Estados, que agiram de tal forma que o seu modo de proceder incluiu e significou adesão, ao menos tácita, a elas. Por mais longe que estudemos a formação dos usos e a transformação deles em costumes, ela se operou da maneira seguinte: - as relações dos Estados exigiam certas regras de proceder, usos singulares criaram-se entre eles, agindo os povos de um mesmo modo, quando aparecia uma ocasião oportuna.

No fim da Idade Média, desenvolvendo-se extraordinariamente o comércio, e aumentando as relações entre os povos, mais se tornou necessário o aparecimento de regras reguladoras dessas relações. Essas regras, tiradas de reflexões religiosas, morais, históricas e racionais, esses usos e costumes reguladores das relações entre os povos cristãos da Europa, formariam mais tarde o Direito das Gentes.

Foi então que Hugo Grócio reuniu, com o seu "DE JURE BELLI AC PACIS", todas as regras que então regiam as relações internacionais, formando um corpo sistemático, uma verdadeira consolidação de costumes internacionais (58), e a sua obra era tão perfeita e se adaptava tão bem ás necessidades do momento que se tornou a base de todo o desenvolvimento posterior do Direito das Gentes.

Mas, sem a convicção dos governos e da opinião publica dos Estados civilizados de que essas regras deveriam ser legalmente obrigatórias, de um lado; e, sem a pressão dos interesses dos Estados, de outro, o Direito Internacional nunca se formaria. No século XIX, verificando-se a obscuridade e a insuficiência dos usos e costu-

(58) LAFAYETTE, § 10 (leitura muito proveitosa). 
mes, novas regras foram criadas por meio dos tratados. Assim as regras convencionais criaram-se ao lado das costumeiras.

Novos Estados admitidos na Família das Nações aceitam as regras nela em vigor.

Não podem, contudo, aceitar umas, e outras não, salvo quando, cúmo no caso da CONVENÇÃO DE GENEBRA, são obrigatórias unicamente para partes contratantes, ou para os Estados que a elas aderiram posteriormente.

Tambem um Estado não pode declarar, num dado momento, que não se submete mais a uma regra de Direito Internacional. 0 corpo das regras que se aplicam na Família das Naçôes, só pode ser alterado por consentimento comum, e não por declaração unilateral de um Estado (59).

Isto aplica-se ás regras costumeiras e convencionais, e violaria evidentemente o Direito Internacional o poder signatario da Declaração de Paris de 1856 , que declarasse que deixava de ser parte nela. Mas é bom observar que isso não se dá quando um dos Estados se reserva o direito de denúncia.

\section{CONCLUSÃO} mento da maioria esmagadora dos Estados civilizados, ou, em última análise, na convicção profunda que os Estados têm de que se devem submeter a essas normas jurídicas. Perguntar porque os Estados estão convencidos de que o Direito Internacional é obrigatório, investigar o motivo da obrigatoriedade das normas juridicas, é questão que não interessa absolutamente. Existem certas normas, os Estados estão convencidos de que devem respeitá-las: é o bastante.

\section{DIREITO INTERNO E DIREITO INTER- NACIONAL \\ 1 - OPPEnheim - I, pag. 24. \\ 2 - Accioli - pag. 15. \\ 3 - Orrvi - pag. 53}

E' radical a diferença entre o Direito Interno e o Direito Internacional. Quem melhor tratou da matéria foi o eminente TriepeL, no seu monumental trabalho sobre o assunto (60), e no seu curso na Academia de Direito Internacional de Haya (1923).

(59) R. Roxburgh - Rev. Am. Der. Int. - 1920 - t. 14, ns. 1 e 2, pag. 25 - La Sanción del Der. Int.

(60) Droit International e Droit Interne - par Henri TrusPEL - Trad, de R. Brùnet - (1920): 
Sintetizando os seus profundos e sábios ensinamentos e os do preclaro professor de Cambridge, Oppenheim, diremos que o Direito Internacional e o Direito Interno diferem:

$10^{\circ}$ - pelas suas fontes;

$20^{\circ}$ - pela sua própria substância;

$3 .^{\circ}$ - pelas relações que regulam.

Pelas suas fontes, porque as do Direito Interno são os costumes que surgiram nos limites territoriais do Estado e as leis emanadas do seu Poder Legislativo, e as fontes do Direito Internacional são os costumes que surgiram das relações entre os Estados e os tratados celebrados pelos membros da Família das Nações.

Pela sua própria substância, porque o Direito Interno é um Direito do soberano sobre os indivíduos e o Direito Internacional não é um direito sobre os Estados, mas um Direito entre Estados soberanos.

Quanto ás relações reguladas, o Direito Interno regula as relações entre os indivíduos de um Estado ou entre Estados, quando não atuam na qualidade de Estado (DrEna, 21) ou entre esses indivìduos e o Estado, e o Direito Internacional regula relações entre os Estados membros da comunhão internacional (segundo TrIEPEL o Estado está ligado pela vontade comum).

$E^{\prime}$ por 'isso que afirmamos que, sendo o Direito Internacional um Direito entre os Estados, estes são as únicas pessoas internacionais. Talvez a dissolução do Estado moderno ponha em seu lügar grandes grupos econômicos, e então teremos um Direito Internacional completamente novo (61).

O Direito Interno e o Direito Internacional são portanto sistemas jurídicos distintos.

Atualmente a necessidade de preeminência do Direito Internacional é quasi geralmente admitida (SÉFÉRIAdÈs, v. 34, pag. 135, Cours, V. 'T. Arrêt, n. 7, Cour Just. Int.).

Realmente, o Direito Interno está subordinado ao Internacional (Diena-Kelsen), visto que este póde exigir que o Estado adote certas normas (62).

(61) Quid sit futurum cras, fuge quaerere (Horacio, Od. L. I. Od. 9-A. V. 13) "Les formes sociales et politiques de l'avenir sont imprevisibles et l'histoire ne saurait nons aider en aucune façon à en penetrer le mystére" (NITTI, Dem., I, p. 98) "Les penseurs les plus éclaires ne peuvent jamais prévoir les formees sociales de l'avenir" (id.).

(62) Verdross - Cours - 50, p. 307. 
Muitos Estados consideram o Direito Internacional como um dos seus elementos. Assim a Constituiçâo Alemã diz que as regras geralmente conhecidas do Direito das Gentes são consideradas como fazendo parte integrante do Direito do Império Alemão com força obrigatória (Constituição alemã, 11 de Agosto de 1919, art. 4.․).

Hildebrando Accioli, no seu tratado recente (1933), ensina que a tese da primazia do Direito Internacional pode ser aceita em outro sentido, diferente do conceito monista. Sem dúvida, nas relações entre o Direito Internacional e o Direito Interno a preeminência cabe ao primeiro. Isto, porém, não significa que os dois não girem em esferas distintas, ou, conforme observa Anzilotr, que o poder do Estado seja uma delegação do Direito Internacional. E a verdade é que, enquanto as normas deste só têm eficácia entre as pessoas da ordem internacional, as regras nacionais só sạo eficazes na ordem interna do Estado á qual pertencem. Por outro lado, as relações regidas por um são diferentes das relações regidas pelo outro.

Dissemos já que, em varios paises, o Direito Internacional, no todo ou em parte, é adotado pelo Direito Interno.

Nos Estados Unidos da América, a Constituição Federal, no art. 6. ${ }^{\circ}$, al. 2. a, declara: "A presente Constituição, bem como as leis dos Estados Unidos que, em virtude dela, forem feitas, e todos os tratados celebrados sob a autoridade dos Estados Unidos constituem a suprema lei do Pais". Além disto, a mesma Constituição, no art. 1.o, secção 8.a , confere ao Congresso Americano a faculdade de definir e punir os delitos contra o Direito das Gentes.

Na Alemanha, a Constituição do Reich, promulgada a 11 de Agosto de 1919, determina, no art. $4 .^{\circ}$, que "as regras do Direito das Gentes, geralmente reconhecidas, serão consideradas como parte integrante do Direito do Estado (Reich Alemão)"

Na Austria, a Constituição Federal, de 1920, dispõe, no art. 9., "as regras geralmente reconhecidas do Direito das Gentes valem como parte integrante do Direito Federal".

As constituições nacionais da Argentina e da Venezuela contêm disposições mais ou menos semelhantes a essas (63).

ATAQUES A' DOUTRINA DUALISTA
Esta teoria dualista, defendida por Triepel, Oppenheim e Anziloti, foi atacada rudemente por Duguit, KRABBE e KeLSEN, três juristas de fama mundial. Vejamos a opinião de KeLSEN: E' impossivel afirmar que dois sistemas juridicos têm validade um ao lado de outro. E' pre-

(63) Hildebrando Accioly - Tratado de Direito Internacional Público, tomo I, p. 16. 
ciso pois admitir a unidade lógica do Direito Interno e do Direito Internacional - teoria monista. A teoria dualista pretende que os dois direitos se opõem pela diferença de vontade de suas fontes. Mas é metodicamente inadmissivel derivar o Direito de uma vontade humana.

Operar do conceito de vontade, é operar de um conceito sociológico, ou psicológico, e não de um conceito jurídico. Introduzindo este conceito no domínio da ciência jurídica, comete-se um crime de sincretismo de método. 0 próprio direito é vontade. Não é uma vontade humana que cria o Direito. A ciência jurídica não é como a sociologia uma ciência que se ocupa do sêr, mas uma ciência do dever. E' uma ciência normativa, refere-se só a normas. Ora, a validade de uma norma depende sempre de uma outra norma de que provém. Devemos pois imaginar todo o sistema jurídico como uma gigantesca pirâmide, cuja ponta seja uma norma suprema, chamada norma originária. Como esta norma não pode ter uma norma superior, e como a validade de uma norma deve depender de outra norma, a norma originária é uma norma hipotética.

Assim, ha unidade de sistema, pois todas as normas dependem de uma norma originária. Não pode, portanto, haver contradição entre o Direito Internacional e o Interno.

Já explicámos esta doutrina (64). Para outros, como Verdross, o Direito Internacional funda-se na regra PACTA SUNT SERVANDA, regra hipotética, pois é uma ficção; objetiva, pois é independente da vontade daqueles a quem se dirige (65).

0 positivista ANziLoti aceita a norma fundamental afastandose da tradição da escola positiva.

\section{A DOUTRINA AN- GLO-AMERICANA}

Pensam muitos que na Inglaterra e nos Estados Unidos o Direito Internacional é parte integrante do Direito Nacional (International Law is a part of the law of land). Ora esta regra não vem em HALleck WHEAton, Walker e Twiss e é condenada por Oppenheim (66).

A explicação da frase é simples. A maioria dos internacionalistas ingleses e jurisconsultos do seculo XVII e XVIII considerava o

(64) Veja-se o magnifico trabalho de BENJAMIN AkziN L'École Autrichienne et le fondament du Droit de Gens, (Revue de Dr. Int. 1927, t. 1, p. 342). $50-3$.

(65) Verdross - Cours, t. 16, pag. 280.

(66) I, pag. 26 e 7. Ver contudo Bonfils-Fauchille, I, p. 
Direito Internacional ramo do Direito Natural. Ora sendo assim, a razão, a natureza, são as fontes comuns de ambos os Direitos. Uma contradição entre os dois é impossivel; dessa forma, é a natureza que decidirá a favor de um ou de outro.

Eis a quintessência da antiga doutrina inglesa, segundo TrIEPEL. Resulta que o Direito Internacional Público, em toda a sua estensão (in its full extent) é uma parte do Direito Interno, e ainda a lei interna que incorpora nela as regras do Direito Internacional não cria um novo Direito, mas tem um vallor declarativo unicamente; enfim, em caso de desacôrdo, prefere-se o Internacional, pois é o Direito Natural.

DOUTRINA INGLESA ATUAL

fonte do Direito Interno (Processo Keyn, Cap. do Franconia "Territorial Waters Jurisdiction Act" - 1878).

E' preciso notar ainda, com TRIEPEL, que a doutrina tradicional é mais respeitada nos Estados Unidos (art. 6-- Const.). Mas os tribunais americanos exigem para que um tratado tenha fôrça obrigatória uma proclamação formal dele pelo presidente. "La loi etatique est toute puissant. Mais comme le droit international régit des rapports entre des Etats et que le droit interne régit d'autres rapports, la loi étatique ne peut pas sans transformation changer le droit international en droit interne" (TRIEPEL).
Já dissemos que a base do Direito Internacional é o consentimento comum dos Estados membros da Família das Nações. Ora, este consentimento manifesta-se por dois modos unicamente: ou o Estado dá, tacitamente, o seu consentimento, pelo costume; ou, o afirma, expressamente, pelos tratados (DAvis). Logo duas são as fontes do Direito das Gentes: os costumes e os tratados. A opinião dos juristas (67), as decisões dos Tribunais Internacionais (68), a comitas gentium (comity, convenance, courtoisie internationale) não são fontes do Di-

(67) Oppenheim, I, § 19 e A. J. 1908 - Accioli, ns. 37 e 38. (68) Id. 
reito Internacional, são apenas fatores que influem no seu desenvolvimento (69).

As decisões judiciárias e a doutrina dos publicistas, como decreta o art. 38, 4. ${ }^{\circ}$, do estatuto da Côrte de Justiça Internacional, são apenas meios auxiliares da determinação das regras juridicas (70).

As opinióes dadas pela Cêrte Permanente de Justiça Internacional tambem não são fontes do Direito Internacional.

Atua a Côrte nesse caso como uma autoridade científica. Isso não significa que as opiniões da Côrte não tenham grande importância para a interpretação das normas internacionais.

Muito teriamos a dizer sobre essas duas fontes do Direito Internacional. Em primeiro lugar, observemos que o costume (71) é o habito de agir, claro, contínuo, e com a convicção de ser ele uma norma obrigatória do Direito Internacional (72).

No uso não existe ainda esta convicção da obrigatoriedade da norma. Quando se transforma o uso em costume, é questão de fato (73).

\section{SERA' O COSTUME \\ UM TRATADO TACITO?}

A manifestação de uma certa conduta pressupõe já a existência de uma convicção juridica correspondente. 0 costume é um puro modo de manifestação de Direito. 0 costume, como obser-

va Diena, não se origina só da ação dos govêrnos, mas tambem de atos de pessoas que exercem o poder judiciário ou legislativo (DiENA, pag. 14), isto é, órgãos do Estado, sejam de caracter administrativo, legislativo ou judiciário e não de simples particulares (AxEL MöLLER, pag. 43).

Quando falamos em tratado (74), fonte do Direito Internacional referimo-nos aos tratados leis (75) tendentes a criar uma regra de Direito objetivo: Tratados normativos e não tratados contratos (Diena - Kelsen).

(69) V. Verdross - Cours, 30, p. 305 e 6.

(70) SÉfÉRIAdÈs - Cours, 34, pag. 310 - Accioli, n. 39.

(71) Lafayette, § 5 - Axel Möller, I, p. 61.

(72) Oppen HeIM, I, § 17 - Accioli, p. 20, n. 33.

(73) OPPENHEIM, I, § 17.

(74) Lafayette, $\S 6 .^{\circ}$, - Oppenheim, I, § 18 - Axel Möller, I, p. 59.

(75) Law making treaties - “ as either stipulate new rules for future international conduct or confirme, define, or abolish existing costumary or conventional rules" (Oppenheim, I, $\S 18$ ). 
0 tratado normativo distingue-se do tratado contrato pelo conteùdo. Em caso de contradição entre as normas juridicas que derivam de tratado e usos e costumes, prevalecem as mais recentes (Diena, 16).

Podem, pois, os tratados e os costumes abrogar-se reciprocamente (76).

Observemos contudo que o art. 38, I e II do estatuto da CORTE PERMANENTE DE JUSTIÇA INTERNACIONAL não é contra essa doutrina: estabelece apenas gradação. Essa gradação não significa mudança nas relações tradicionais entre o direito convencional e o costumeiro, mas sim serve para declarar que a lei especial prevalece sobre a geral (77).

E' de notar-se quanto aos princípios gerais de Direito que estes já fazem parte do Direito das Gentes, antes de serem aplicados pela Côrte, pois esta não os cria (Contra Anzilottr; Corso, 3.a ed., pags. 64 e 107).

Os tratados só obrigam ás partes contratantes ou ás nações que lhes prestam adesão (78). Contudo por eles manifesta-se a conciência juridica das nações que os celebram.

Pode-se dai concluir que o Direito que se forma com os tratados tem a sua fonte ou raiz nos usos e costumes (79). E' porisso que os tratados concorrem para a formação do Direito Internacional, mesmo que já não estejam em vigor $(80)$.

(76) Cavaglieri, pag. 73 - Verdross, Cours 30, pag. 303.

(77) Verdross - Cours 30, p. 304 - Spiropoulos.

(78) OPPENHEIM, I, § 18.

(79) E mesmo como observa Oppenheim, I, § 18, o poder do tratado deriva do costume, que é a fonte original do Direito das Gentes (I, § 18): "But it must be emphasised that, whereas custom is the original source of International Law, treaties are a source the power of which derives from custom. For the fact that treaties canstipulate rules of international conduct at all is based on the customary rule of the Law of Nations, that treaties are binding upon the contracting parties". (v. t., id. § 493). Sobre a importância do costume fala JUGLARIS NICIENSES (Juglaris - Elog. Venetiis MDCLXXX - salientando que o costume segue até a outra vida: até no inferno caça Orion, enfurece-se Ajax e se impacienta Agamenon (Eneida) - vivo peregrinava José e quis que peregrinassem, depois de morto, seus ossos (Gen. 50 v. 24) e até em Deus se converteu o costume em natureza.

(80) LAFAYETTE, § 6, p. 12 (nota 6). 
DOMINIO DO DI-

REITO INTER-

NACIONAL

FONTES

1 - LAFAYETtE - \& 13.

2 - Urhman - \& 10.

3 - Verdross - Cours 30, pag.

318 e segs.

1- Lawrence - pag. 3.

5 - AxRL Mö́LLRR - pag. 4.

para os quais é obrigatório".

\section{DUAS DOUTRINAS}

tros afirmam que se aplica TENS).
"Dominion of the law of Nations is the name given to the area within International Law is applicable that is, those States between which International Law finds validity" (OPPENHEIM, I, § 26). Ou, em vernáculo, "Dominio do Direito Internacional é o nome dado á área dentro da qual o Direito das Gentes é aplicavel, isto é, os Estados

\section{FALSIDADE DESSAS DOUTRINAS}

"Dizem uns que se estende o domínio do Direito Internacional a toda a humanidade (Bluntschl, Fiore): ouunicamente aos povos cristãos (MAR-

São opiniões extremas e errôneas. Dizer que se estende a todos os Estados sem excessão é absurdo, porque nem todos compreendem os princípios da moral internacional.

O Direito Internacional formou-se na Europa entre Estados cuja civilização foi criada e desenvolvida pela aplicação dos preceitos do cristianismo (81). Até princípios do século passado vigorava só entre as nações da Europa e as colônias européias da America (82).

Só se póde aplicar, portanto, o Direito Internacional ás relações de todos os Estados que atingiram a um certo grau de civilização idêntica. Não se aplica, portanto, aos povos bárbaros (DienA, 28).

Afírmar ser ele aplicavel unicamente aos Estados cristãos da Europa e da América, é desconhecer a sua história: o Japão e a Turquia, por exemplo, fazem parte da Familia das Nações. A Turquia entrou para a Família das Nações pelo Tratado de Paris (30 de Março de 1856, art. 70). E' de notar que até o Tratado de

(81) Bonfils-Fauchille, pag. 28, n. 41.

(82) O Direito Internacional é na origem um produto da civilização cristã (it is in its origin essentially a product of christian civilisation) - Oppenheim, I, $\S 10^{\circ}$ e 26 - Verdross, Cours, Hap. 30, p. 318. 
Kutchuck kainardji (1774), a Porta não celebrava com as nações cristãs Tratados de Paz, mas sim somente treguas (83).

TEORIA VERDADEIRA

o Direito Internacional aplica-se aos povos cristãos e aos que, não sendo cristãos, se submetem, expressa ou tacitamente, aos seus princípios, baseados na moral cristã. O Japão entrou para a Família das Nações, porque adotou a civilização ocidental, fundada na moral cristã (84), os principios do Direito das Gentes europeu, formulados de acôrdo com a moral de Grócro, o pai do Direito Internacional, que era cristão e aplicava ás relações internacionais os principios da moral cristã, que se tornou a moral internacional. o Dominio do Direito Internacional é portanto o seguinte:

1) Estados civilizados da Europa da América (cristãos);

2) Estados não cristãos que se submetem expressa ou tacitamente aos princípios do Direito Internacional, como a China, o Japão e a Turquia.

Ha ainda Estados de posição duvidosa, como a Pérsia, o Sião, etc. Estes, só parcialmente fazem parte da Família das Nações. Contudo, devem ser tratados com humanidade, o que nem sempre acontece (85). Para exemplo do procedimento dos povos cristãos em relação aos Estados mais fracos, basta que lembremos o que foi a ocupação das Indias pelos ingleses ou o procedimento das tropas européias na China. Diz Nrrtr: "Quando os exércitos de ocupação europeus foram á China, após a revolta dos boxers, os instintos de rapina se revelaram subitamente, e os povos civilizados e demo-

(83) Butler and Macoby - Dev. p. 20 - Teoricamente o.islamismo está sempre em guerra com os não crentes. Francisco I foi certamente um benemérito celebrando o tratado de Belgrado (1535).

(84) Referindo-se ao Japão diz NitTr: "Ce grand pays a acompli la transformation économique la plus rapide dont l'histoire de la civilisation humaine garde le souvenir: tout en conservant une grande partie de ses traditions et de ses principes d'ordre religieux et moral, il a adopté les méthodes de production de l'Europe et de l'Amérique, il est devenu une grande puissanse, il a vaincu la Chine et la Russie et il a pris une part importante à la Guerre européenne" (Dem. II, p. 309).

(85) OPPENhEiM, I, § 29 - LAFAYETTE, introdução - E' dificil conceber-se hoje Estados fora inteiramente da Família das Nações. Talvez possam ser exemplos o BUTAN, o NEPAL e o THIBET. 
cráticos rivalizaram no roubo e nas violências mais crueis. Os chefes dos Hunos nunca jamais falaram a linguagem estúpida e feroz de Guilherme II. (Dem. II, pag. 176). E' ainda o grande escritor italiano que diz, no maior livro do século: "L'Histoire de la colonisation européenne au cours du dernier siècle n'est qu'une suite d'horreurs et de crimes..." (Dém. II, pg. 312).

Delaisi sintetizou a história colonial como uma série de crimes e rapinas baseando-se em documentos oficiais e em boletins das missões (Bulletin des Missions des Benédictins belges, 1929, 30/31), que nos revelam os tráficos imorais dos povos civilizados que chegaram a adotar o trabalho forçado dos indigenas. Esses principios de moral internacional hoje são obrigações legais para os Estados civilizados (86).

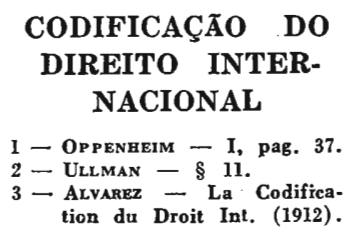
guem esta corrente, que o Direito Internacional seja codificado paulatinamente. Outros escritores desejam codificar o Direito das Gentes de uma só vez, que se organize de um jato um Código de Direito Internacional.

Para eles, devem ser reunidas de uma só vez e em um só momento, as regras de Direito Internacional em um conjunto sistemático, em um Código. O primeiro sistema foi adotado pela Sociedade das Nações, e pelo Instituto de Direito Internacional, como diremos mais tarde. O segundo método, isto é, o daqueles que desejam fazer um Código de uma só vez, reunir em um conjunto sistemático todas as regras de Direito Internacional, foi adotado pelos Estados americanos, a princípio, na 2. ${ }^{\mathrm{a}}$ e $3 .^{\mathrm{a}}$ Conferências Pan-Americanas (Mexico, 1901, e Rio de Janeiro, 1907).

Em 1912 foi apresentado um projeto de Código de Direito Internacional Público e outro de Direito Internacional Privado. 0

(86) Não confundimos D. e Moral internacional: apenas afirmamos que o Direito baseia-se, funda-se na Moral. As obrigações morais podem tornar-se legais. (V. Kraus, La Morale Int. - Cours, 1927, I, p. 389; e AXEL Möller, I, § 23 ns. 5 e 6). 
projeto de Código de Direito Internacional Público, apresentado em 1912 pelo Govêrno Brasileiro na Conferência do Rio de Janeiro, foi redigido pelo grande jurisconsulto pátrio Dr. Epitacio PessôA. Mais tarde tiveram os Estados americanos de mudar de orientação devido ás idéias de Alexandre Alvarez, um dos mais ilustres jurisconsuiltos do mundo. Dizia que um Código deve consistir em um conjunto de acêrdos concernentes, não a todas as matérias do Direito Internacional, mas, unicamente, a certas partes do Direito, principalmente levando-se em conta as tendências do Direito Internacional Americano.

Para Alexandre Alvarez, não se deveria fazer um Código de Direito Internacional completo, de uma só vez, mas dever-se-ia ir codificando paulatinamente as diversas matérias de Direito das Gentes. E' um Código progressivo, mas neste Código progressivamente feito deve-se reservar uma grande parte ao Direito Internacional Americano, cuja existência é proclamada por Alexandre Alvarez.

Foi esta a idéia que triunfou no projeto do Instituto Americano de Direito Internacional e no projeto da Comissão de Juristas no Rio de Janeiro em 1927, e, finalmente, na 6.a Conferência Pan-Americana.

Si as idéias de Alexandre Alvarez triunfaram quanto ao Direito Internacional Público, não triunfaram quanto ao Direito Internacional Privado, permanecendo, nesta matéria, a orientação primitiva. dos Estados americanos. Assim a Conferência de Havana adotou um projeto do grande jurisconsulto cubano BUSTAMANTE.

o Código BUSTAMANTE

A Sexta Conferência Internacional Americana, realizada em 1929 , em Havana, República de Cuba, por ato de 28 de Fevereiro, aceitou, com algumas

modificações, e reservas de certas delegações, o projeto apresentado pelo sábio jurisconsulto cubano ANTonio Sanchez de Bustamante ao Congresso de Jurisconsultos Americanos reunidos no Rio de Janeiro.

Esta convenção mereceu, entre nós, a aprovação do Congresso. Nacional (decreto n. 5.647, de 8 de janeiro de 1929), tendo sido publicada pelo decreto n. 18.946, de 22 de outubro do mesmo ano, o qual mandou executar e cumprí-las tão inteiramente como se contém nos seus textos. 
UrRutia (87) e Bento de Faria (88) salientam que a caracteristica da Convenção de Havana consiste em que nela se quiz principalmente confirmar e precisar certos Direitos do Estado em relação aos estrangeiros.

São princípios correntes, geralmente consagrados pelos países contratantes, apenas reafirmados como regras uniformes para vigorar harmonicamente entre eles, com o propósito de aproximá-los e proscrever antecipadamente o maior número de dúvidas de possivel occorrência.

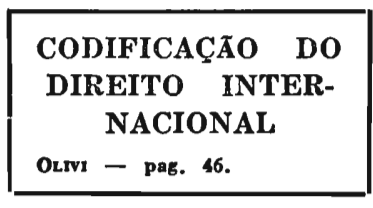

A falta de precisão das regras do Direito Internacional originou a tendência para a sua codificação. Foi Bentham o primeiro que teve a idéia de codificar o Direito das Gentes (século XVIII) (89). A segunda tentativa para codificar o Direito Internacional foi a da Convenção Francesa de 1792. O projeto da Convenção Francesa (1795) é obra do abade GrÉgorre e pode ser visto em RIvier, v. I, pg. 40.

Em 1861, Petruscheveg publica o seu Código de Direito Internacional. Em 1872, aparece o célebre projeto de Dudley Field. Mas já em 1868, Bluntschli publicara o seu notavel Código que teve um sucesso mundial e é um dos trabalhos mais acatados sobre a matéria. Em 1889, surge Frore com o seu Direito Internacional codificado. Podemos apontar ainda os trabalhos de Duplessix, 1906, de Internoscia (1910), e finalmente Epitácio PessóA, em 1911, surge com o seu monumental CODIGO DE DIREITO INTERNACIONAL PÚBLICO. Além desses trabalhos, ha outros e ainda numerosas tentativas parciais.

Em 1873, fundou-se uma associação para reforma e a codificação do Direito das Gentes (Associação de Direito Internacional). Em 1880, funda-se em S. Petersburgo uma associação análoga. Um dos escopos do Instituto do Direito Internacional, fundado em GAND, em 1873, é a codificação do Direito Internacional, e idêntico fim é procurado pelo Instituto Americano de Direito Internacional, fundado em Washington em 1912 (90).

(87) Le Continent Américain et le Droit International, Francisco José Urrutia, 1928; Cours 1928, vol. 22, pag. 206.

(88) Da condição dos estrangeiros e o Código do Direito Internacional Privado.

(89) Bentham's-Works, ed. Bowing, VIII, p. 537.

(90) Maiores particularidades encontram-se em Oppenheim, I, p. 37 . 


\section{SERA' POSSIVEL A CODIFICAÇĀO DO DIREITO INTER- NACIONAL?}

Discutem os autores, e muito, sobre as vantagens e desvantagens da codificação do Direito Internacional. Essa controvérsia é ociosa: a tendência hodierna é para a codificação (91). Vejamos, pois, si é esta possivel. Objetam,

em primeiro lugar, que um legislador universal, um corpo legislativo para o mundo inteiro, implica uma organização central da Humanidade, o que é uma verdadeira utopia, uma quimera. Não vejo porque. Tudo tende para esta organização. H. G. Wells, na sua magnifica obra "FAILLITE DE LA DEMOCRATIE", salienta que o homem cada vez se torna mais cidadão de um mundo dividido ainda por pequenas pátrias.

Ataca o grande escritor violentamente o conceito da soberania, e conclue que o único caminho para a paz universal é a FEDERAÇÃO MUNDIAL (92).

Esta organização não é uma utopia, a própria Liga das Nações quasi que compreende todos os Estados civilizados. A Liga das Nações é um exemplo vivo de que pode existir um poder legislativo universal. Podemos dizer, ainda, que para codificar-se o Direito Internacional não é preciso esse legislador universal. Prova disto é que existe hoje o Direito Internacional Público Unıversal obrigatório para todos os Estados civilizados sem excessão, mesmo sem a existência deste legislador universal e único; e, si existe um Direito Internacional universal, si varias partes do Direito Internacional Público são obrigatórias para o mundo inteiro, porque não podemos conceber que o que acontece para uma parte do Direito Internacional possa, tambem, acontecer para todo o Direito das Gentes?

Existe o Direito Internacional Universal (93), submetem-se os Estados a certas normas uniformes, deliberações de órgãos internacionais são respeitadas pelo mundo inteiro. Podemos, portanto, concluir que é possivel a existência de um legislador universal e que

(91) history has given its verdict in favour of Codification (OPPENHEIM, I, p. 9).

(92) De modo idêntico pensa Peritch, (Zeitschrif für Int. Recht. 1931) eminente professor de Belgrado. Acredita ele na paz eterna pela transformação do Direito Internacional $\mathrm{em}$ Direito Interno, construido o estado mundial único. Mas, infelizmente, estamos bem longe de tal desideratum.

(93) LafayetTe, $\S 70^{\circ}$, pag. 14. Refere-se aos TRATADOS UNIVERSAIS e diz: “Esta espécie de tratados dá testemunho de que, sobre certos assuntos, todas as nações podem chegar a acordos precisos e definidos" 
mesmo sem esse legislador não é absurda a codificação do Direito Internacional. Dizem mais que o Código Internacional só seria possivel si fosse redigido em uma língua universalmente adoptada, si o projeto fosse votado em bloco por todos os Estados, sem exceção.

Essas condições, afirmam, são insuperaveis. Não concordamos. Achamos que, com o tempo, com boa vontade, se conseguirá suplantar todas essas dificuldades.

A existência de uma língua única, de uma língua universal, seria muito vantajosa para a fraternidade universal. Mas a inexistência dessa língua universal não é obstáculo á codificação do Direito Internacional, pois existe o Direito Internacional Universal (94).

Em segundo lugar, pode-se dizer que esta lingua existe, pois o francếs pode ser considerado verdadeiramente como a língua diplomática (95).

AS CODIFICAÇões PARCIAIS
Sou favorabilissimo ás codificações parciais do Direito Internacional. Esta, como diz Diena (pag. 37), são indubitavelmente mais faceis, uteis e práticas (96).

Não podemos deixar de nos referir á Associação Francisco Vitória, fundada na Espanha, em 14 de julho de 1926, para afirmar a existência de uma escola espanhola de Direito Internacional. Quanto á Liga das Nações, nascida do PACTO que constitue a parte primeira do Tratado de Versailles, não póde considerar-se como um órgão idôneo para produzir diretamente uma codificação do Direito Internacional.

Na 5.a Assembléia da Sociedade das Nações, celebrada em Genebra em 1924, acordou-se constituir, junto da Sociedade, um Comité de juristas para preparar uma lista das matérias de Direito Internacional, ácerca das quais uma codificação fosse desejavel e realizavel, e dar comunicação aos Estados da lista assim preparada.

A Assembléia, em 27, declarou que uma Conferência Internacional se reunirá em 1930 para tentar a estipulação de uma ou várias convenções coletivas sobre três das matérias propostas pelo comité

(94) Ver LORIMER - p. 268, sobre as vantagens de uma lingua universal.

(95) Veja-se: Oppenheim, I, pag. 44 (§ 25).

(96) Oppenheim, I, p. 46 - Contra: Rodrigo Octavio - Rev. D. I., p. 46. 
de juristas. E realmente a conferência de codificação reuniu-se em Haya (13 de março de 1930), com resultados mui modestos, não chegando a aprovar nenhum convênio, mas sómente algumas recomendações aos Govêrnos (97).

O MAIOR OBSTÁCU-

LO A' CODIFICACĀO DO DIREITO INTERNACIONAL

0 maior e o mais formidavel obstáculo á codificação do Direito Internacional é a má fé dos Governos dos Estados, a serviço da politica imperialista das grandes potências, os grupos oligárquicos, os opressores dos povos, que maquiavelicamente iludem as massas para explorá-las em proveito próprio. 0 meio mais seguro de se obter a codificação do Direito Internacional é lutar-se pela liberdade dos povos.

No dia em que triunfar a verdadeira democracia, o Direito Internacional será facilmente codificado, acabar-se-ão com as guerras, e reinará a paz entre os homens. 
HISTORIA DO DIREITO INTERNACIONAL

1 - OP PENheiM - I, pag. 48.

2 - Celestivo Ferretra - El

Derecho In ernacional en la antiguedad $y$ en la Edad Media - Caracas, 1927.

3 - Laukent - Histoire du Droit des Gens.

4 - Accrour - n. 45.

5 - Olivi - \$ 5. , pag. 15

6 - Lawrence - pag. 17

7 - FkRREYha - n. ${ }^{\circ} 8$.

8 - Halleck - $\$ 10^{\circ}$

9 - Butham-Maccos - The Development of Int. Law (1928).

10 - Cruchaga - pag. 9. vel que a idéia de uma Família de Nações surgisse no limitado horizonte mental do mundo antigo. Cada nação tinha sc.ıs Deuses, sua língua e sua moralidade próprias.

0 estrangeiro era considerado inimigo. Não havia então interesses internacionais que ligassem com vinculo inquebrantavel os Estados numa comunhão internacional. Entravam contudo as nações antigas em relações umas com as outras, faziam a guerra, celebravam a paz, enviavam embaixadores, aliavam-se, e tais atos davam nascimento, está claro, a usos e costumes. É essa a remota origem do Direito Internacional, mas esses costumes, conquanto uniformes e interessantes para o Direito das Gentes, não poderiam ainda constituir o Direito Internacional, tal como é concebido modernamente. o Direito Internacional pressupõe, como ensina AXEL MöLler, a existência de vários Estados independentes, com um certo nivel uniforme de civilização, ligados entre si em uma comunhão internacional.

(98) Axel Möller, Int. Law, pgs. VII, 11, 44. 


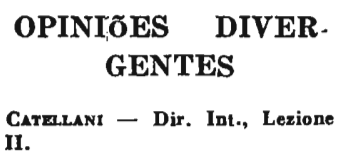

vestigações históricas provaram que o mundo antigo conhecia perfeitamente o sentido das relações internacionais e aplicava um sistema de instituições muito desenvolvidas e firmemente estabelecidas. Apela para as leis de HAMmurabi, os PAPIROS EGIPCIOS, as TáBUAS BABILONICAS e ASSÍRIAS para sustentar a sua tese. E tira a conclusão de que o Direito Internacional é antiquíssimo, é uma consequência de toda a civilização (100). E a velha tese de MoviTESQuiev (101). Depois de firmar que o Direito das Gentes é naturalmente fundado sobre os principios de que as nações si devem fazer na paz o máximo de bem possivel, e na guerra o mínimo de mal possivel, sem prejudicar os seus verdadeiros interesses, afirma o genial escriptor francês:

"Todas as nações têm um Direito das Gentes; e os próprios Iroqueses que comem os seus prisioneiros, o têm. Enviam e recebem embaixadas; conhecem os direitos da guerra e da paz: o mal é que esse Direito das Gentes não é fundado sobre verdadeiros princípios"

Atribue KonfF a opinião contrária á sua á ignorância das civilizações antigas por parte dos internacionalistas do século :XIX. Estas, segundo ele, só foram estudadas e ensinadas modernamente por Chybichowshy, Vinogradoff, Rostofvseff e outros.

(99) W. Beach Lawrence - Commentaire sur les Élements du Droit Int. de Wheaton (1868), p. 99.

(100) De grande utilidade para os que querem ter uma idéia exata dos fatos históricos é a consulta da monumental obra de BURET DE LONGGHAMPS - Tableaux Chronologiques (MDCCCXXI) e F. LAurent - Etudes sur l'histoire de l'Humanité (18 vols). Tenho contudo para mim que a história longe de ser ". testis temporum, lux veritatis, vita memoriae magistra viteae. " a que se refere CICERO (De Oratore, lib. II, cap. 36), é melhor caracterizada por GisBON quando diz: "History which is, indeed, little more than the register of the crimes, follies, and misfortunes of Mankind. (V. t. NiTTI - Dem. I, p. 90)". Decline and fall of the Rom. Empire, ch. 3. NitTr (Democratie, I, p. 82) mostra o absurdo de se dizer que a história é a mestra da vida. Sendo o estudo da história. de grande auxílio para o Direito Internacional, consultar-se-á com vantagem, para a política européia: A. Debidoun - Histoire Diplomatique de l'Europe. Seignobos - Histoire Politique de l'Europe Contemporaine.

(101) De L'Esprit des Lois, I. I., cap. III. 
Aponta casos para provar a antiguidade do Direito Internacional e de suas regras, sancionadas pela religião.

Considera, por exemplo, uma descoberta de Summer, de 4 mil anos antes de Cristo, e diz que recentemente se descobriu um tratado, assinado pelo rei ENTEMENA, regulando as fronteiras entre o seu reino de LAGASH e o reino vizinho de UMMAH.

Por esse tratado foi designado um árbitro, o rei MISILIM DE KUSH. Eis aí o arbitramento. Recorre á história do Egito. RAMSÉS II concluiu em 1820 A. C. um tratado com o rei vencido dos HITTITES, HAUSILITT, no qual aparece um sistema perfeitamente regulado e complicado de extradição de refugiados políticos.

Ora, ninguem nega essas afirmações, o que se contesta é a existência entre os antigos de um Direito das Gentes, tal como é modernamente considerado.

De opinião semelhante á de KorfF é Nippold.

\section{OPINIXO DE NIPPOLD}

No curso professado pelo grande internacionalista suisso NipPoLd, na Academia de Direito Internacional de Haya (1924), podemos acompanhar a sua argumentação.

Afirma que o Direito Internacional deve ser estudado sem preconceito, "sub specie aeternitatis": pois é um Direito que existiu em todos os tempos e no seio de todas as civilizações. Afirma com Korf a antiguidade do Direito Internacional, e que ele era conhecido pelas antigas povoações da Árica.

E contesta, além disto, que o Direito Internacional seja um produto da raça branca. O japonês Ukita tambem diz que, si dermos crédito aos historiadores europeus, a história da Humanidade seria a história da raça branca.

Segundo o historiador Takahashi, o Japão, antes de ter relação com os europeus, já conhecia o Direito Internacional e aplicava suas regras. $O$ mesmo se poderia dizer da China, segundo $W$. Martin (China Kodai Bankoku Koho).

Conclue Nrppold, dizendo que a primeira lição a tirar do estudo da história do Direito Internacional é uma lição de modéstia. O patrimônio que nos legaram as antigas civilizações é imenso, e não devemos desprezá-lo.

Si o Direito Internacional deve muito á moral cristã, diz ele, não devemos esquecer que nos estados budistas se faz notar, quando se trata da história da Europa, que as guerras são mais numerosas nos Estados cristãos. Com efeito, o Japão, durante 250 anos e até a chegada dos estrangeiros, gozou de uma paz ininterrupta. Mas. 
mitiga a sua opinião dizendo que o cristianismo é uma religião tão pacífica como o budismo, e que se não deve culpar nenhuma destas religiões pelos erros dos homens de Estado e da grande política ou pelas lacunas do Direito das Gentes.

\section{CONCLUSAO}

Cristã como dissemos Gentes é um produto da Moral Cristã, como dissemos atrás, acompanhando OPPENHEIM. Regras isoladas regendo relações entre os povos não constituem ainda o Direito Internacional, direito que regula relações de uma "FAMfLIA DE NAÇõES” (102).

A CIVIlizaÇÃo E' DA RACA BRANCA o Direito Internacional, como vimos, baseia-se no consentimento da maioria esmagadora dos membros da comunhão internacional, e esta adotou para moral a moral cristã, que é a moral internacional. Si as nações civilizadas da Europa em cujo seio se formou o Direito Internacional fossem budistas ou maometanas, si a essas religióes pertencesse Hucio Grócro, o fundador do Direito das Gentes, outra seria, evidentemente, a moral internacional.

Não se póde tampouco culpar essa moral, como confessa NipPoLd, pelos erros dos govêrnos.

Como veremos mais tarde, muito tem progredido o Direito das Gentes, sob o influxo da moral ocidental. E ociosa, segundo creio, a discussão sobre si a nossa moral é superior ou inferior ás outras: - não discutiremos o que deveria ser, mas sim, expomos somente o que é, na realidade.

Os japoneses não são inferiores aos brancos e nem a sua civilização é peior do que a nossa; são apenas diferentes. No momento atual do mundo prevaleceu a nossa civilização, a civilização ocidental ou cristã. Os japoneses foram obrigados, portanto, a se submeter aos principios que prevalecem hoje na Familia das Nações. Vai da nossa doutrina ao ponto de vista norte-americano, um abismo. 0 japonês em nada é inferior ao americano ou ao australiano, como salienta Nıtrı (Dem. II, p. 309). A hostilidade á imigração japonesa tem por causa interesses econômicos. Muitas vezes os próprios trabalhadores no govêrno do Estado são ainda mais brutais do que capitalistas. É o que aconteceu na Austrália e na Nova Zelândia.

(102) C. Bevilaqua - Est. Jur. - p. 85. 
Meia duzia de trabalhadores de uma pseudo democracia-socialista pretende explorar um continente em proveito próprio, excluindo os trabalhadores japoneses, italianos, etc. E interessante: os govêrnos socialistas mais hostis ao proletariado dos outros povos que os próprios capitalistas!

Diremos, de passo, que a religião cristã não provocou guerras, e que só por fatos excepcionais houve poucas lutas entre Estados não cristãos.

O Japão, por exemplo, com quem guerrearia, e para que?

A principal razão das guerras entre os Estados é a luta de interesses, é o capitalismo, a ambição dos govêrnos, e estas coisas, segundo creio, não existiam no Japão.

Demais, logo que ele quis entrar para a Sociedade Internacional, teve que se submeter aos princípios da moral cristã, isto é, da moral internacional.

Civilizações mais requintadas do que a nossa têm existido: a chinesa, a grega, etc. No entanto, em primeiro lugar, eram rudimentares no seu aparelhamento, no seu equipamento. Na nossa civilização predomina o elemento material. Deste ponto de vista, somos muito superiores aos antigos. Entramos numa fase nova, inteiramente diversa das anteriores. Essa exploração intensiva do planeta foi feita sob a égide do ocidente, sob a direção da raça branca.

Passou em julgado que a nossa civilização difere das anteriores unicamente quanto á parte material, o que não nos parece verdadeiro. Quanto ao elemento material não ha duvida: libertar-se o homem das coisas, dominar cada vez mais a natureza, é sinal de civilização. Hoje o mundo tornou-se pequeno, as vias de comunicação o cortam em todas as direções, o telégrafo, o telefone, a aviação, o automovel, encurtam cada vez mais o nosso planeta, unem os continentes, aproximam os povos.

Mas, intelectualmente, tambem ha o aumento dos conhecimentos das massas, a difusão científica, fenômenos essencialmente modernos, consequência da Democracia. Ainda a nossa civilização é superior a todas as outras, porque cada vez mais vencemos a dor, o sofrimento.

Do ponto de vista moral mesmo, a nossa Justiça é mais perfeita e corresponde mais ás necessidades da coletividade. Triunfou definitivamente o princípio de que ninguem é Juiz em causa própria, a vida e a propriedade de todos é garantida. Aumentou além disso a Piedade e a solidariedade humana e social.

A democracia é hoje uma consequência da democratização da vida e, cada vez mais, o que não se dava nas civilizações anteriores, 
os progressos e os benefícios da sociedade são vantajosos e de proveito para a massa dos indivíduos. Essa a tendência da nossa civilização que se encaminha inelutavelmente para a crescente democratização da vida e para um regimen cada vez mais democrático.

\section{DIVISÃO DA HISTó- RIA DO DIREITO INTERNACIONAL \\ 1- Calvo - vol. I. \\ 2 - OPPEnHeim - vol. 1 .}

belecidos, levando marcaram época na história das Relações Internacionais. Este é o mais geralmente aceito.

\section{DIVISÃo DE}

OPPENHEIM

\section{tes de Grócio; segundo, depois de Grócio.}

OPPENHEIM, que vamos seguir passo a passo na exposição deste ponto, divide a história do Direito Internacional em dois periodos principais: primeiro, an-

Leva, pois, em consideração o aparecimento da obra monumental de Grócio - DE JURE BELLI AC PACIS, em 1625, que é o ponto de partida de todo o desenvolvimento posterior do Direito das Gentes.

Cada um desses grandes períodos é subdividido por OPPEnHeim em vários outros, cada um deles marcado por um acontecimento notavel, síntese de uma época histórica, com influência no desenvolvimento posterior do Direito Internacional.

\section{PRIMEIRO PERÍODO}

ANTES DE GRÓCIO

1 - Axre Mörler - ps. 11 e 44 (periodo anterior a Grócro).

Como dissemos anteriormente, na antiguidade não encontramos o Direíto Internacional tal como é concebido modernamente, pois ele é um produto da civilização cristã e tem apenas 400 anos

de existência. Mas, já então vamos encontrar os usos e costumes que mais tarde viriam a formar o Direito das Gentes.

Desde o princípio dos tempos históricos o homem teve que entrar em relação com os seus semelhantes.

Divididos em tribus, cuja grande lei era o isolamento, tinham os povos primitivos que entrar fatalmente em contato com os outros, pelo menos nas relações bélicas. Uma tribu guerreava com outra, 
faziam-se tratados para celebrar a paz, eram ás vezes enviados embaixadores, cuja inviolabilidade era sancionada pela religião. Iam, está claro, surgindo dessas relações alguns usos, e nos casos idênticos procediam esses povos da mesma forma, de tal sorte que esses usos se transformavam paulatinamente em costumes internacionais.

É essa a remota origem do Direito das Gentes.

Vejamos quais eram esses costumes entre os povos mais importantes da antiguidade.

\section{OS JUDEUS}

1- Calvo - I, pag. 2.

2 - Ferreyra - n. ${ }^{\circ} 29$, pag. 71.

3 - WHOOLSEY - 19 e segs.

4 - Halleck $-\$ 20$.
Tratemos em primeiro lugar dos judeus. Apesar de serem monoteistas, e de muito mais elevada moralidade e civilização que os seuś vizinhos, os judeus não tiveram grande influência no desenvolvimento do Direito Internacio-

nal. Desprezando as outras nações, o povo eleito não podia considerá-las como iguais. Apenas, no modo por que tratavam os estrangeiros, mostravam os judeus o seu elevado nivel moral. Examinando-se alguns textos da Bíblia, vê-se que com os escravos estrangeiros eram mais brandos que todos os povos da antiguidade.

No Exodo (XII - 20, 26 e 27) encontramos os seguintes preceitos: "O que ferir o seu escravo ou a sua escrava com uma vara, e eles thes morrerem nas suas mãos, será culpado deste crime" "Se alguem ferir o olho do escravo ou da escrava, e os deixar cego de um dos olhos, os deixará livres pelo ôlho que lhe tirou"

No Deuteronômio $(\mathrm{X}-19)$ se nos deparam os textos ordenando "amai os peregrinos, porque tambem vós fostes estrangeiro na terra do Egito".

No Levítico $(19,33$ 34) se preceitua: "Se algum forasteiro habitar na vossa terra, e morar entre vós, não o impropereis: mas esteja entre vós, como se fosse natural; e o amareis como a vós mesmos. Porque tambem vós fostes estrangeiros na terra do Egíto". E ainda: "Seja entre vós igual a Justiça, ou delinquisse o forasteiro, ou o compatriota".

Nas suas relações bélicas faziam os judeus uma distinção interessante, assinalada por OPPENherm, entre os inimigos capitais e os simples inimigos (103).

(103) Duo Bellorum genere apud hebraeos: Quedam Dei precepto necessaria, quaedam sponte suscepta. Primi generis Deo indicta, ut in Amalecitas, chananaeos. devotas gentes (Amalech-Agag Dictionarium Historicum Criticum - Calmet E Gallico in Latinum translatum. A Joanni D. Mansi Venetiis - MDCCXLVII). 
Com os seus inimigos capitais, os amalecitas, por exemplo, eram de uma crueldade extraordinaria (104). Veja-se: Reis (I-15) "Vai pois agora e fere a Amalec, e destróe tudo que ele tiver. Não lhe perdoes a ele, e nem cobice coisa alguma sua: mas mata desde o homem até a mulher e o menino, e o que é de mama, o boi e a ovelha e o camelo e a ovelha".

No mesmo livro, versículo $\mathrm{X}$ e seguintes, vemos SAMUEL por ordem de DEUS repreender a SAUL por não o ter obedecido, fazendo passar a fio de espada os pecadores de Amalec. E logo em seguida vemos SAMUEL matar a AGAG: "XXXII - E disse SAMUEL. trazeime a AGAG rei de Amalec. $E$ foi-lhe apresentado AGAG, que era mui gordo e todo tremendo. E AGAG disse: assim me separa a morte amarga? - XXXIII - E disse SAMUEL: assim como a tua espada tirou os filhos ás mães, assim perderá a tua mãe entre as mulheres os seus filhos. E SAMUEL o dividiu em quartos diante do senhor em Galgala" (105).

"II - Reis (12 - 31) : - E trazendo os seus moradores, os mandou serrar, e que passassem por cima deles carroça ferrada: e que os fizessem em pedaços a cutelo, e os botassem em fornos de coser tijolos: assim o fez com todas as cidades dos amonitas: e voltou DAVID e todo o exército para Jerusalem"

Quando entravam em luta com povos de que não eram mortais inimigos, procediam mais humanamente do que as outras nações da EPOCA. Assim no DEUTERONOMIO encontramos as leis da guerra: "Si saindo a fazer guerra contra teus inimigos, e tendo visto a sua cavalaria, e as suas carroças, achares que o exército contrário é mais numeroso do que o teu, não os temerás: porque contigo está o Senhor teu Deus, que te tirou da terra do Egíto.

2) E quando estiver perto de se dar a batalha, o pontífice se porá na frente do exército, e falará assim ao povo:

3) Ouve, oh Israel, vós estais hoje para combater contra os vossos inimigos; não se atemorize o vosso coração, não temais, não recueis, nem lhes tenhais medo:

(104) Emilio Ferrière - Los mitos de la Biblia, explica o mito de LOT e suas filhas como uma ficção odiosa para atacar os amonitas e moabitas (p. 164). E' o mesmo Ferrière que explica pelo ódio internacional entre israelitas e cananeus a maldição de Canaan.

(105) 0 horrivel castigo contra Amalec vem descrito belamente por Soares - Bahiense - Progynasma Litterario - p. 613 MDCCXXXVII. 
4) Porque o senhor vosso Deus está no meio de vós, e ele pelejará por vós contra os vossos inimigos, para vos livrar do perigo;

5) Os oficiais tambem cada um na frente do seu corpo dirão gritando, ouvindo o exército: Ha algum homem que tenha edificado uma casa nova e a nîu tenha ainda estreiado? Va-se, e torne para a sua casa: não suceda que ele morra no combate, e outro a estreie;

6) Ha algum homem que tenha plantado uma vinha e ainda não tenha feito comum, para que todos possam comer d'ela? Vá-se e torne para sua casa: não suceda que ele morra na peleja, e faça outro o que a ele lhe tocava;

7) Ha alguem que se tenha desposado com uma mulher, e todavia a não tenha ainda em seu poder? Vá-se, e torne para sua casa: não suceda que ele morra na batalha e algum outro a tome;

8) Ditas estas coisas, acrescentarão eles, e dirão ao povo o seguinte: Ha algum medroso e de coração tímido? Vá-se e volte para sua casa: para não fazer desmaiar os corações de seus irmãos, assim como ele está assustado de medo;

9) - E logo que os oficiais do exército se calarem, e acabarem de falar, cada um preparará os seus esquadrões para a batalha;

10) - Quando te chegares para combater uma cidade, primeiramente lhe oferecerás a paz;

11) - Se ela aceitar, e te abrir as portas, todo o povo que houver nela será salvo, e te ficará sujeito pagando tributo;

12) - Mas se não quizer aceitar as condições, e começar a fazer a guerra contra ti, atacá-la-ás.

13) - E quando o Senhor teu Deus ta houver entregado ás mãos, passarás ao fio da espada todos os varões que nela haja.

14) - Reservando as mulheres e os meninos, os animais e tudo o mais, que se achar na cidade. Distribuirás o esbulho todo pelo exército, e sustentar-te-ás dos despojos de teus inimigos que o Senhor teu Deus te tiver dado;

15 - Assim é que has de fazer a todas as cidades que estiverem muito longe de ti, e não são daquelas que has de receber em possesão;

16) - Quanto áquelas cidades porém, que te hão de ser dadas, nenhum absolutamente deixarás com vida;

17) - Mas passa-lo-ás todos a fio de espada; convém a saber, aos hetheus, e aos amorrheus, e aos cananeus, aos ferezeus, e aos heveus e aos jebuseus, assim como o Senhor teu Deus te mandou;

18) - Para que não suceda que vos ensinem a cometer todas as abominações que eles mesmos fizeram a seus Deuses, e venhais a pecar contra o Senhor vosso Deus; 
19) - Quanto te detiveres muito tempo no sítio de uma cidade, e a tiveres cercado com máquinas para a tomares, não cortarás as árvores de cujo fruto se pode comer, nem deves deitar abaixo a golpes de machado os arvoredos do país circunvizinho: porque isto são paus, e não homens, nem podem aumentar o numero de teus inimigos.

20) - Mas se houver algumas árvores que não sejam frutiferas, mas silvestres, e boas para outros usos corta-as, e engenha delas máquinas, até que tomes a cidade que peleja contra ti".

Compare-se o procedimento dos JUDEUS com o dos outros povos antigos e mesmo dos tempos modernos.

E' verdade, como diz Nirrr (Dem. 2, pag. 281), que nenhum povo agiu tanto sobre a civilização moral do mundo como os hebrcus: deles é o nosso Deus, e deles tambem a nossa creação religiosa, o Cristianismo. Ainda dos hebreus nos veiu a sua criação moral, o socialismo. Este povo insignificante que nunca conheceu o repouso, atormentado, perseguido, cada vez mais forte depois da ruina, cada vez maior depois das perseguições, é o que a civilização produziu de mais admiravel. E' não só a maior glória da civilização moral, como tambem uma das suas maiores fôrças de propulsão e de vida.

A superioridade dos judeus sobre os outros povos é manifesta, e daí o antisemitismo.

Quasi tudo que ha de mais elevado na nossa civilização, na nossa moral, o sentimento de justiça e os mais sábios ideais de fraternidade humana, é de origem hebráica (106).

A guerra foi a relação normal entre os povos da antiguidade. Fazia-se ela de uma maneira crudelíssima. Lembremos o modo por que os assírios tratavam os vencidos.

Diz Albert Malet (107): Os assírios eram impiedosos para com os vencidos. Infligiam-lhes os mais atrozes suplicios: furavam-lhe os olhos, cortavam-lhes o nariz, as orelhas, e os lábios, arrancavam-lhes a barba e as unhas, ou ainda os empalavam e os esfolavam vivos.

Elevavam troféus com cabeças cortadas. Atiravam os cadaveres ás bestas feras. Vangloriavam-se os Reis destes atos de selvageria: de dois matei um, diz ASSURBANIPAL, e levei os sobreviventes como escravos. Construí uma pirâmide diante da porta da

(106) V. T. Clovis Bevilacqua - Estudos Jurídicos, p. 60-1. (107) L'Antiquité, pg. 56. 
cidade. Esfolei vivos alguns dos chefes da revolta e estendi suas peles sobre esta pirâmide. Outros foram emparedados vivos, outros empalados, etc. Sobre as ruinas a minha fisionomia expandiu-se na satisfação do meu ódio encontrei o meu consôlo.

Os Deuses da antiguidade eram sanguinários. O Deus caldeu ou assírio era um senhor exigente e sanguinário, Deuses dos seus povos como ISTAR em NINIVE ou MARDUK em BABILONIA. Para eles os estrangeiros eram os inimigos (108).

Lembremos uma inscrição de ASSURBANIPAL: os homens cuja boca tramara complots contra ASSUR e contra mim, tiveram a língua arrancada, etc. Fazendo estas coisas regosijei o coração dos Deuses.

Faziam exceção na antiguidade os PERSAS. Vencedores foram sempre dóceis e clementes para com os vencidos. Lembremos a bondade e a extrema generosidade de CIRO (109). Assim mesmo, podemos dizer que, sendo a guerra a forma normal das relações entre os povos da antiguidade, ela serviu de ponto de união para as civilizações.

o comércio era insignificante e não ligava os povos como atualmente. E' por uma longa série de guerras que se penetraram as duas civilizações, a do NILO e a do EUFRATES.

Se o problema da paz internacional é, antes de tudo, moral, dependendo da perfeição da alma humana (110), podemos considerar - Decálogo a magna carta da humanidade civilizada.

O cristianismo iria contribuir no futuro para realizar os ideais de paz e amor entre os homens. Tornando-se religião universal, o cristianismo funde os principios monoteistas da religião mais severa da antiguidade com o cosmopolitismo grego, obtido através da unidade do império Romano: temos então a PAX ROMANA.

Estava reservado ao Cristianismo tornar as nações concientes do seu fim político comum, e, em combate de alguns milhares de anos, pela evolução aperfeiçoadora da humanidade estabelecer o fundamento do Direito Internacional e da Paz mundial.

Diz muito bem J. Miller (111) que a ação de propaganda intelectual e moral da Igreja cristã pela paz é importantíssima, ao lado do desejo constante de multiplicar as instituições pacificas. Este

(108) Sobre a origem do sacrificio, leia-se E. O. JAMES - Origens of sacrifice - A Study in Comparative Religion.

(109) MALET - citado, pag. 122.

(110) MöLler - Cours de la Académie de Droit International de la Haye.

(111) Oeuvre des Eglises pour la Paix. 
trabalho de propaganda é importantíssimo. Só os ignorantes ou os de má fé negarão a importância extraordinária dela.

Wells, na sua linda obra "Faillite de la Démocratie", salienta a necessidade e a importância de uma propaganda pacifista, como veremos mais tarde. $E^{\prime}$ preciso realmente crearmos uma atmosfera psicológica sinceramente pacifista.

o Direito Internacional nasceu, a princípio, no solo católico, é obra dos mestres espanhois do Direito Natural, fundado na sabedoria de Aristóteles e no trabalho filosófico de Santo Agostinho e São Thomaz de Aquino. Mas depois de Grócio, sua formação foi feita quasi exclusivamente pelos protestantes.

Realmente, todo movimento pacifista contemporâneo foi inspirado pelos protestantes ingleses e americanos. Não desprezando, conquanto menor, a importância da Igreja Ortodoxa, que teve no seu seio Dostorewsky e Tolstor, somos forçados a reconhecer a ação formidavel das diversas seitas protestantes. Vejam-se a respeito as páginas eloquentes escritas sobre a politica inglesa nas fndias pelos protestantes a Pio IX, e lembrem-se da ação de David Urquhart, inspirador da petição do Sínodo patriarcal dos Bispos aramênios de Constantinopla ao CONCfLIO DO VATICANO (112).

Ainda hodiernamente causam admiração os ideais messiânicos (Isaias, II - 2-4): "E nos últimos dias estará preparado o monte da casa do Senhor no cume dos Montes, e se elevará sobre os outeiros, e concorrerão a ele todas as gentes.

E irão muitos Povos, e dirão: vinde e subamos ao monte do Senhor, e á Casa do Deus de Jacob, e ele nos ensinará os seus caminhos, e nós andaremos pelas suas veredas: porque de Sião sairá a Lei, e de Jerusalem a palavra do Senhor.

E julgará as nações, e arguirá a muitos Povos: e das suas espadas forjarão relhas e arados, e das suas lanças fouces: não levantará a espada uma nação contra outra nação, nem daí por diante se adestrarão mais para a guerra".

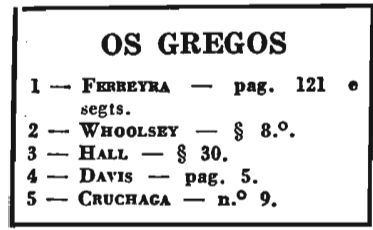

As nações, ou melhor as cidades gregas, independentes, e, ao mesmo tempo, inter-dependentes, dão-nos o primeiro exemplo de um Direito baseado no consentimento comum, regulando as relações reciprocas dos Estados soberanos (113). Antes da conquista Macedô-

(112) David Urquhart, some Chapters in the life of a victorian Knigth - errant of justice and liberty, by Gertrude RoBinson, Oxford - 1920 .

(113) Catellani: Dir. Int. - p. 15; Oppenheim - I, § 39. 
nica, encontramos a Grécia dividida em uma porção de cidades independentes. Mas os gregos não se podiam esquecer de que tinham a mesma língua, a mesma raça, adoravam os mesmos Deuses, animava-os idênticos ideais de civilização. Por isso eram essas cidades independentes ou soberanas, inter-dependentes, formando uma comunhão internacional, uma verdadeira "Família de Nações"

Conquanto crueis nas guerras com os bárbaros, observavam entre si regras restritas de conduta, e tinham usos internacionais muito brandos e humanos.

Reconheceram sempre a SANTIDADE DOS CONTRATOS, e si observarmos que a religião era tudo na antiguidade, concluiremos que uma regra baseada em uma sanção religiosa estava muito mais garantida até do que atualmente quando certos govêrnos declaram os tratados "trapos de papel".

Como faz notar Nippold, confundiam-se outrora o Direito e a Moral, 'mas essa confusão era menos nociva do que a invenção de um Direito Internacional amoral (114).

Ao lado das Federações politicas gregas como a Liga Amphyctiônica, desenvolveu-se o belo INSTITUTO DO ARBITRAMENTO (115). As práticas guerreiras, entre gregos, eram brandas, e não se fazia a guerra sem prévia declaração.

Pela neutralização de certas pessoas e lugares, contribue a Grécia para tornar a guerra menos deshumana. Não conhecem os gregos o cortejo triunfal dos orientais e dos romanos, nem os troféus tomados no campo de batalha e que perpetuam a lembrança da guerra.

O modo de guerra dos helenos é muito mais civilizado do que o dos outros povos da antiguidade. Salienta J. Müller (116) que em relação aos orientais e aos Judeus a concepção grega da justiça e da guerra internacional justifica e representa um grande progresso. Os gregos não conhecem inimigos de Deus, no sentido oriental. Quanto ao destino dos povos, adotam de antemão a fórmula de FrEDerico Schiller: “A História é o Tribunal do Mundo". Este ponto de vista é favorecido por reinar entre os Estados gregos uma in-

(114) A esse proposito diz Gumplovicz: “A moral é a própria vida, é a fonte do Direito. O que hoje é Direito, ontem foi moral, daí toda a moralidade tender a tornar-se Direito. A moralidade é o direito que dormia na vontade popular" (Dr. Polit. Fil. 3). Não é outra a lição de AXEL MöLLER: "Like all other law international Law rests, in the last instance, upon an ethical basis" (I, p. 6å).

(115) Tod, International Arbitration amongst the Greeks (1913). Ralston, International arbitration from Athens to Locarno (1929).

(116) Curso de Haya, vol. 31. 
constância perpétua da fortuna militar e uma tirania fundada unicamente na fôrça das armas não poder se prolongar muito tempo (117).

A casta sacerdotal não era favoravel ás guerras. A sacerdotiza Theano (118), cinco séculos antes de CRISTO, na época da guerra do Peloponeso, recebe oficialmente a ordem de pronunciar fórmulas de maldição. Mas responde com dignidade: "Sou sacerdotiza para abençoar, e não para amaldiçoar"

Praticarem as cidades gregas a extradição de criminosos. Mesmo quanto aos estrangeiros, deram o exemplo de instituições tendentes a protegê-los. Lembremos os proxenes, guarda da hospitalidade, e os Tribunais para estrangeiros.

Não nos devemos esquecer do cosmopolitismo grego. Sócrates já dizia: "sou um cidadão do mundo"; e, quatro séculos antes de CRISTO, SópHocles coloca na boca de sua Antígone a lei fundamental do amor ao próximo.

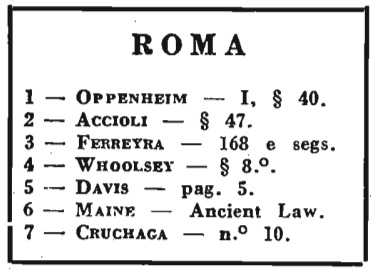

Devemos distinguir nas relações de Roma com os outros povos dois casos principais :

(117) Mesmo com os outros povos os gregos eram relativamente brandos na guerra. Exemplo, a generosidade de Alexandre em relação a Pono (Histoire Universelle - trad. de l'Anglois par une Société de Gens de Lettres, Amsterdam et à Leipsig - chez Arks fée et Merkus - MDCCLI, vol. XIII, p. 70). Si notamos este procedimento de Alexandre, não podemos deixar tambem de nos referir a Asoka - V. NiTTI, Dem. I, p. 321.

(118) Theano sacerdotiza do tempo de Agraule - Plutarque - Les vies des Hommes illustres - tomo II, pg. 263 (Alcibiades). Sobre Alcriades: Justinus - Lib. $5 .^{\circ}$ - cap. 8, Xenophonte Histo. G. L. I - Thucidides - lib. 5.5.7.8.

(119) Accioli, § 47 - Histor. Univ. par une société de Gens de Lettres MDCCXLVII (p. 43 e 49 , t. VIII). Em Tito Livio, L. I., cap. 25 , vêm particularidades interessantes sobre as atribuições dos feciais. Refere-se a decisão entre Roma e Alba, por meio dos Horácios e Curiácios, bem como ao Tratado então celebrado, modelo dos futuros tratados, que seriam celebrados pela cidade Eterna. 
1) - Roma tinha tratado com o povo estrangeiro;

2) - Roma não tinha com ele nenhum tratado.

Na primeira hipótese as relações eram minuciosamente reguladas pelo Direito.

Com o correr dos tempos, foi tal a quantidade de estrangeiros em Roma que se formou para eles o JUS GENTIUM, aplicado pelo PROETOR PEREGRINUS.

Os tratados de Roma com os outros povos eram:

1) — de amizade (amicitia);

2) - de hospitalidade (hospitium);

3) - de aliança (foedus).

Ás vezes nos tratados combinava-se que qualquer dúvida posterior seria decidida por árbitros, os recuperatores.

Quando não havia tratado de aliança, dominava o arbítrio. A pessoa que entrasse no território romano era escravizada, e assim o romano que penetrasse no território estrangeiro era reduzido tambem á escravidão (exceto os embaixadores). Contudo, quando voltavam novamente á pátria os escravos tornavam-se livres pelos JUS POSTLIMINII.

A guerra era uma instituição legal, com regras precisas. As justas causas de guerras eram:

1) - a violação do dimínio romano;

2) — a violação dos embaixadores;

3) - a violação dos tratados; e

4) - o auxilio aos inimigos de Roma.

E sómente começavam a guerra os romanos si satisfações não eram dadas a Roma.

A guerra era sempre crudelissima (120). Terminava:

1) - por tratado de paz;

2) - pela DEDITIO, e

3) - pela OCCUPATIO.

Ad instar da proxenia existia em Roma o patronato, em virtude de que determinados estrangeiros ou povos tinham um defensor das suas pretensões legítimas em um cidadão romano.

o patrono de toda a Sicília era Cícero.

(120) O próprio Cesar não primava pela bondade. Apontaremos o seu procedimento no cerco da ALESSIA e para com VERCINGETORIX. Mesmo com os heróicos hermínios procedeu ferozmente, como narra Manoel Faria e Souza, na sua Historia del Reyno de Portugal (En Bruselas, MDCCXXX - cap. X, pag. 71), obra interessantíssima e digna de meditada leitura. NiTTi, Dém. I. p. 366. 
Finalmente Caracalla aplicou a todos os habitantes do Império o Direito Romano.

Como veremos mais tarde, o Direito Romano, a razão escrita, muito influiu no desenvolvimento do Direito Internacional.

Não podemos dizer contudo que em Roma existisse um Direito Internacional como o concebemos modernamente (121). O mesmo poderemos dizer da Grécia. Na Grécia o Direito Internacioňal tinha uma aplicação restrita: as AMPHYCTIONIAS, uniões para defesa dos seus interesses comuns, dão-nos o exemplo de uma verdadeira Família de Nações.

Roma era um Império Mundo (WORLD EMPIRE). E necessário para a existência do Direito Internacional uma base de costumes comuns e concepções jurídicas comuns.

Diz muito bem Diena (122) que uma sociedade de Estados, o que nós denominamos Comunhão Jurídica Internacional, só se forma quando existe uma pluralidade de Estados que entram em relações recíprocas, submetem-se a certas normas, e tem uma comunhão de idéias morais e jurídicas, isto é, o que se denomina "conciência jurídica comum".

\section{A IDADE MÉDIA}

1 - Ferrorra, pag. 225 e segts.

2 - WhOOLSET, \& $8 .^{\circ}$.

3 - Cruchaga, ns. 11 e seg'B.
Variam muito os historiadores na determinação das épocas históricas. Alguns prolongam a Idade Média até a renascença das letras e das artes, outros até a queda do feudalismo. Podemos, si atendermos unicamente ao desenvolvimento intelectual, limitá-la por Santo Agostinho e BoÉcio, de um lado, e por Bacon e DescarTES, de outro (domínio da Escolástica).

Não errariamos se a prolongassemos até a Reforma, ou ainda até quasi o fim do século $\mathrm{XV}$, em que são fatos notaveis o desabamento do IMPÉRIO DO ORIENTE, a conquista de GRANADA, a invenção da tipografia, a união da Bretanha, o ultimo grande feudo, a França, o descobrimento da América e o nascimento de Luthero.

Vulgarmente adopta-se a seguinte divisão da História: ANTIGUIDADE, desde os mais remotos tempos até a queda de Roma (476); IDADE MÉDIA, de 476 a 1453 (tomada de Constantinopla); IDADE MODERNA, de 1453 a 1789 (revolução francesa); e, IDADE CONTEMPORÂNEA, de 1789 até hoje.

(121) SÉfériadìs, Cours, t. 34, pag. 228. - Axel Möller, p. 13, (122) Derecho Internacional Publico, 1932, pag. 7. 
Como ensina KoRFF, os historiadores costumam dividir a IDADE MÉDIA em dois períodos:

$10^{\circ}$ ) - do século $\mathrm{V}$ ao $\mathrm{X}$, ou "IDADES SOMBRIAS" (Darkages); e,

$\left.2 .^{\circ}\right)$ - do XI ao XVI.

Roma era um Império Mundo (World Empire) absorvendo todos os povos antigos. Dificilmente poderiam os Romanos conceber um Direito destinado a regular relações de Estados soberanos, pois estes não existiam.

A religião cristã ainda veiu aumentar a unidade do Império (momentaneamente).

As coisas continuaram neste pé mesmo depois da divisão do Império (395).

Em 476 dá-se a queda de Roma (123) e ROMULOS AUGUSTULUS, o último imperador, é substituido pelo chefe bárbaro ODOACRO, começando a Idade Média.

Os bárbaros invadem o império. Nas Gallias surge o reino dos francos com CLODOVEU, em 476. Vencido ODOACRO por THEODORICO em 473, forma-se na Itália o reino dos OSTROGODOS.

Em 456, o reino dos Visogodos é estabelecido na Espanha. Os vândalos formaram um reino na África, tendo CARTHAGO por capital. Os saxões tomaram pé na Bretanha, em 449.

Estes povos que repartiam entre si o império eram bárbaros e não estavam em condições de assimilar a cultura dos vencidos. Muitos anos foram precisos para que se erguessem a um nivel moral e intelectual, próximo do romano.

Adotaram a religião cristã e a civilização romana, mas dificilmente poderiam pretender tornar-se romanos.

Contudo ha exagero por parte daqueles que afirmam ter a cultura romana desaparecido inteiramente. Germens de cultura subsistiam aqui e alí, escolas e homens notaveis mantinham a tradição da cultura antiga. Lembremos somente BOÉCIO e a Escola de Ravenna, que atravessou todo esse periodo de obscurantismo, e foi como que o ponto de partida da celebre escola de Bologna (Clovis Bevilaqua, Estudos Juridicos, pag. 81).

Realmente, depois da queda do Império do Ocidente e durante os governos ODOACRO e dos OSTROGODOS, a instrução mante-

\footnotetext{
(123) Dialogos de Varia Historia - Pedro DE MARIz MDCCXLIX.
} 
ve-se ainda ordenada, como ensina Federico Ciccaglione, na sua excelente História do Direito Italiano, o mesmo acontecendo com a reconquista de JUSTINIANO.

Deixando de parte as minúcias, podemos dizer que nas provincias bisantinas da Itália, além de escolas que poderemos dizer secundárias, existiam as superiores para o ensino do Direito: Roma e Ravenna.

A escola de Roma foi continuação da famosa Escola existente em Roma durante o império, mantendo a mesma organização.

A Escola de Ravenna surgiu certamente depois de JUSTINIANO, sendo impossivel precisar a época do seu nascimento.

Discute-se ainda muito a origem da Univercidade de Bologna (G. Manacorda, Storia della Scuola in Italia, Palermo, 1914). Contudo parece-nos indubitavel que a Escola de Bologna nada mais é do que transformação da de Ravenna (124).

Em 800, CARLOS MAGNO restabeleceu novamente a unidade e foi coroado IMPERADOR ROMANO pelo Papa Leão II.

O império Franco durou pouco, pois em 845, pelo tratado de VERDUN, se fracionou em três partes, que foram o embrião de onde mais tarde se formariam as diversas nações européias.

Na IDADE MÉDIA, poder-se-ia ter formado um Direito Internacional perfeito, como observa SÉfḱriadÈs, mas isso, infelizmente, não aconteceu (125).

(124) Veja-se Federico Ciccaglione - Manuale di Storia del Diritto Italiano. TARLAZzi, La Scuola di Diricto Romano in Ravenna, ed. in Bologna. Ricci - Origini dello Studio Ravennato. Rrvalta, Discorso sopra la scuola delle leggi romane in Ravenna ed il collegio dei giureconsulti ravennati. Ravenna, 1888. ScHupfer, Le Università ed il diritto, nel vol. III dell'opera: Gli albori della vita italiana, Milano, 1891. La scuola di Roma e la questione in irneriana, in Memorie della R. Accademia dei Lincei, 1897. - SARTI, De claris Archigymnasii bononiensis professoribus a saæculo XI usque as sæculum XIV. Bonaniae, 1769-1772, n. ed Bologna, 1889. Malagola, Monografie storiche sullo studio bolognese, in Bologna, 1883. CHIAPPELLI, Lo studio bolognese nelle sue origini e nei suoi rapporti con la scienza preirneriana, Pistoia, 1888. GLoria, Autografo di Irnerio e origine delle università di Bologna, Padova, 1888. Tamassia, Bologna e le scuole imperiali di diritto, in Archivio giuridico, 1888. Patelta, La scuola giuridica constantinopolitana del secolo XI e la scuola di Bologna, negli studii storico-giuridici offerti a F. Schupfer, Torino, 1898. Zacharia von Lingenthal, Il diritto romano nella bassa Italia e la scuola giuridica di Bologna, in Rendiconti del R. Instituto Lombardo, 1885. RIvIÉR, L'Université de Bologna et la première rênaissance juridique, in Nouvelle Revue historique, 1888.

(125) V. T. Axel Möller, p. 13. 
NOS SECULOS XV E XVI
Nos séculos XV e XVI, o Direito das Gentes torna-se indispensavel na Europa. Nesse pequeno continente, surgiu uma multidão de Estados abso-

lutamente independentes. Com o desenvolvimento extraordinário do comércio nessa época, estabeleceram-se as relações entre os povos. Era indispensavel que um Direito aparecesse para regular essas relações.
Ensina OpPenherm que nessa época sete fatos influiram grandemente no desenvolvimento do Direito Internacional. Vejamos quais foram:

\section{FATORES QUE IN- FLUIRAM NO DE- SENVOLVIMENTO DO DIREITO IN- TERNACIONAL NESSA EPOCA}

1) Os civilistas e canonistas. O renascimento do estudo do Direito Romano, com IRNERIo, os glosadores e postglosadores, que reputavam este Direito, o Direito por excelência, a RATIO SCRITA, não poderia deixar de influir grandemente na formacão de um Direito que se criava nessa época. Como a ciência grega, o Direito Romano desaparecera só aparentemente da Europa. Com a invasão dos bárbaros, povos ignorantes e devido ao proselitismo de uma nova religião, a Filosofia grega, a ciência helénica transportou-se para a Ásia. Numerosos sábios e filosófos gregos refugiaram-se na Côrte Persa, formando-se no Oriente um importante núcleo intelectual que floresceu principalmente em Bagdad, enquanto baixava o nivel mental europeu. "Mais tarde, quando os arabes derramandose pelo Norte da África, se apoderaram da Espanha, e vieram ameaçar toda a Europa, que naturalmente dominariam, si os guerreiros de Carlos Magno não os tivessem detido em Tours, trouxeram todo o tesouro da Filosofia e da ciência dos gregos, e, assim, determinaram uma revolução no mundo, fomentaram a renascença, fizeram com que os modernos conhecessem as obras antigas: as científicas, sobretudo de Alexandria, e as filosofias da Grécia. Por esse modo, se estabeleceu, ou antes, se restabeleceu a unidade do pensamento científico e filosófico" (CLovis Bevilaqua, Estudos Juridicos, pg. 74).

Em relação ao Direito, observa Cuovis Bevilaqua, as coisas se passaram de outro modo mas o resultado foi o mesmo. O Direito romano esteve sempre como lei dominando na Europa. Não foi um elemento posto á margem, atirado fora por algum tempo e descoberto por povos de outra origem, que novamente o restituiram á Europa. Hoje a lenda da descoberta de um exemplar das Pandec- 
tas em Amalfi, ao tempo de Lothário II, está completamente desmoralizada depois dos estudos de Savigny sobre a História do Direito Romano na Idade Média (126).

É de notar que os civilistas consideravam o Direito Romano o Direito do mundo civilizado, e tratavam de várias matérias internacionais comentando o CORPUS JURIS.

Os canonistas, por sua vez, discorreram sobre a guerra, procurando abrandá-la, torná-la mais humana (127).

2) As coleções de leis marítimas. No século VIII, começou o comércio marítimo a desenvolver-se, e apareceram costumes marítimos, reunidos em corpos de leis. As mais notaveis dessas leis maritimas foram o "Consolato del mare" (sec. XIV) de Barcelona; as leis de Oleron (sec. XIII); a lei Rhodia (sec. VIII ou IX); as leis de Wisby (sec. XIV), da ilha de Gothland na Suécia. Destas leis a mais importante é o Consulado do mar (LAFAYETTE, pag. 21).

3) As ligas de cidades - o terceiro fator foram as ligas de cidades para proteção de seu comércio. A principal delas é a Liga Hanseática (128).

4) As embaixadas permanentes.

5) Os exércitos permanentes.

6) A renascença e a reforma.

Diz muito bem OpPenherm (1-pag. 60) que a renascença das ciências e das artes no seculo XV, juntamente com a ressureição do conhecimento da antiguidade, reviveu os ideais filosóficos e estéticos da vida grega, e os transferiu para a moderna. Surgiu a convicção de que os principios cristãos deveriam ser observados tanto em matéria nacional como internacional. De outro lado a reforma pôs fim á supremacia do Papa sobre o mundo civilizado.

Os Estados protestantes não poderiam reconhecer mais o poder arbitral do Papa. Si é verdade que o Código da Ética Cristã contido no Novo Testamento serve como regra de conduta das relações internacionais, e como ponto de referência para se saber si um procedimento é justo ou injusto, conforme ensina Davis (129), póde-se calcular a influência extraordinária da reforma, conside-

(126) V. Clovis Bevilaqua - Estudos Juridicos. Savigny Hist. du Dr. Rom. au Moyen Age, trad. Guenoux - 1830.

(127) LAFayeTte - $\S 10$ e 11.

(128) Butler and Maccoby, pag. 24.

(129) International Law, pag. 28. 
rada por Calvo como um dos mais notaveis acontecimentos da história do mundo.

Ensina NitTi (130) que os homens que vivem na nossa civilização obedecem ás mesmas paixões e seguem em parte os mesmos instintos que os seus antepassados. Somente as idéias morais e os sentimentos de ordem elevada determinam grandes movimentos da humanidade e contribuem para o seu aperfeiçoamento.

Interpretações arbitrárias de hipóteses cientificas, como o transformismo, a evolução, a hereditariedade das qualidades adquiridas, durante muito tempo entretiveram as ilusões mais absurdas. $O$ que ha de melhor em nós, o que atenua a violência dos instintos, das paixões, é apenas o fruto das grandes concepções morais e religiosas. O próprio socialismo não poude implantar-se solidamente sinão nos paises penetrados do espirito de ISRAEL e da civilização cristã.

Esta influência extraordinária da reforma no Direito Internacional será por nós estudada detalhadamente em tempo oportuno.

Conquanto Grócio procurasse remontar o Direito das Gentes aos gregos e romanos, os autores modernos não aceitam tal tese. O sonho de dominacão universal, acalentado pela Roma antiga, era a negação do Direito Internacional.

A Igreja herdou de Roma (131) o desejo da unidade, aspirando organizar a Monarquia Universal.

A Igreja cedeu mesmo á tentação de reivindicar o reino deste mundo, idéia repelida por CRISTO (S. Matheus - 48).

(130) La Démocratie, 1933, pag. 12.

(131) Virgilio (Eneida, I, 278; IV, 227, 231; VI, 851-853) proclamava o destino de Roma: exercer uma soberania a qual os deuses não impuseram nenhum limite, no espaço e no tempo. Dante, seguindo o poeta, proclamava a missão de Roma divina e sua história um milagre da Providência. Roma a cidade eterna, séde do Império Universal, devendo o próprio Cristo ser considerado romano (1.: Com. Purg. 102 - De monarchia II, 4, Niтrri, Dém. 2.0, p. 277, descreve magistralmente a luta entre a Igreja católica e o Estado. Mostra o grande escritor que a Igreja de Roma, onde tudo se vende (Dante, Par. XVII, 51), nunca deixou de sonhar com a dominação universal. Em uma Democracia o regimen da separação da Igreja e do Estado é o unico meio de existirem os dois poderes sem conflitos permanentes. O conflito histórico entre a Igreja e o Estado só pode ser solucionado pela separação completa e com a liberdade religiosa plena, absoluta, irrestricta. Sempre que o catolicismo dominou soberanamente, abafou a liberdade e impediu o progresso econômico e social (p. 279). Não nos devemos esquecer nunca de que "l'opposition fondamentale entre catholicisme et démocratie, entre catholicisme et liberté ne disparaitra jamais.. (NITTI, Dém. $2 .^{\circ}$, p. 284). 
Apontemos os Papas. Gregorio VII condena o poder temporal dos Príncipes (Epistolae, Lib. VIII, I-21), sendo o Papado o Sol e a realeza a Lua; o sacerdócio tendo sido instituido por ordinationem divinam e a realeza per extorsionem humanum, o poder sacerdotal é superior ao civil, como a alma ao corpo. Durante toda a Idade Média a Igreja trabalhou por obter o predominio dessa tese teocrática da unidade do mundo (132).

Triunfasse a Igreja e o Direito Internacional não poderia se desenvolver sob sua influência, como observa Fauchille (vol. I, pag. 73). O absolutismo eclesiástico é ainda muito mais perigoso do que o leigo, pois se funda na vontade insondavel de DEUS e não conhece limites.

A unidade desejada pela Igreja é incompativel com - Direito Internacional, e a Igreja era no fundo inimiga das Nações. Estas se constituiram graças á Reforma, quando os príncipes se oppuzeram ás pretenções dos $\mathrm{Pa}$ pas. A Reforma estabelecendo a autoridade da Escritura Santa, concorreu para excitar a atividade intelectual do povo e para a instrução, bem como para o aparecimento das literaturas nacionais. A Reforma é que fez penetrar na vida moral dos povos no século XVI as idéias de liberdade religiosa e de liberdade política. Dela se originam todas as liberdades modernas (133).

109.

(132) Laurent, Études sur l'histoire de l'humanité, tomo VI, p.

(133) Les grandes démocraties modernes sont neés dans des pays de civilization chretienne; mais dans des pays où le catholicisme s'était atténue, ou il ne dirigeait plus avec autorité d'État, chez des populations qui, sous l'effet du Protestantisme, s'étaient éloignés du catholicisme (NitTi, La Démocratie, vol. II, p. 247). "Dans les pays d'Europe et d'Amérique, presque tous les grands mouvements politiques qui ont déterminé la formation des démocraties modernes, sont sortis des luttes religieuses contre l'église catholique, et ils ont pris naissance souvent dans des pays protestants" (id. p. 249).

Esta é a these do grande Nitti, que mostra que o fator religioso desempenhou grande papel no nascimento da democracia, sendo sempre um movimento exterior ao catolicismo e mesmo contrário a ele (p. 249 e 254). Da mesma forma o Budismo, na sua essência antes uma filosofia que uma religião, rebaixa o nivel da vida, alimenta nas almas um quietismo mórbido e, conquanto tendo uma moral altíssima, não contribue de forma alguma para a emancipação humana (pag. 249).

"On peut dire que le principe de la liberté moderne, liberté de penser, de se reunir, de discuter, d'avoir une opinion, de la divulguer et de l'enseiger liberté substantielle de l'individu independence de l'État et de l'Église, ont peut dire que cette liberté n'est venu que de la réforme protestante, et que seul l'esprit de la reforme protestante a fait surgir en Amérique la première grande république et la première constitution vraiment démocratique" (Nitti, Dém., 2. ${ }^{\circ}$ p. 270). 
Max Boegner (134) diz que constituidas as nações, devido à Reforma, a ciência do Direito das Gentes data do século XVI. Sómente então os Estados secularizados tornam-se sujeitos de Direito e as relações múltiplas que sua coexistência no seio de uma mesma comunhão humana os obriga a estabelecer entre si na plenitude de sua soberania dão, ao Direito Internacional, o objeto sem o qual ele não poderia existir. GRócro recebeu, como em geral os reformados das provincias unidas, uma forte cultura bíblica. Assim recorre, na sua argumentação, á autoridade divina e cita frequentemente a Bíblia. Os sucessores de Grócio nos séculos XVII e XVIII, Zouich, Pufendorf, Barbeyrac, Burlamaqui, Wolf, WatTel, todos são protestantes, e durante dois séculos o Direito Internacional aparece, como salienta BOEGNER, como sendo uma ciência reformada. Entre todos esses internacionalistas protestantes existe a convicção de que os deveres internacionais são uma categoria dos deveres cristãos. A atuação pacifista dos Reformados foi constante através dos tempos.

Luthero detestava a guerra. Erasmo e Calvino foram pacifistas, e este condena a guerra como uma coisa horrivel e contra a natureza, uma enormidade. Calvino formula claramente as leis da guerra e diz que um povo, levado a uma guerra de defesa, não deve esquecer nunca a solidariedade humana e que todos somos irmãos (Opera, pag. 619). Toda a crueldade deve ser evitada, respeitadas tambem as árvores e tudo que serve de alimento ao povo. A guerra para Calvino não se estende aos não combatentes, cujas vidas devem ser respeitadas. Os QUAKERS desejavam transportar os preceitos de Jesus Cristo relativos ao perdão das ofensas, a não resistência á paz, para o domínio das relações internacionais.

Entre eles salientam-se Wiliam PenN e Antonio Benezet. A organização internacional teve como pioneiros sempre homens imbuidos dos principios da Reforma. Sintetizando o magnifíco curso na Academia de Direito Internacional de Haya, em 1925, em que tratou da influência da Reforma sobre o desenvolvimento do Direito Internacional, MAX BOEGNER, pastor da Igreja reformada da França, assim se expressa:

"Ainsi s'est exercée depuis le XVIème siècle, ainsi s'exerce encore aujourd'hui sur le developpement du droit international l'influence des Églises de la Réforme. Parce quélle est, non pas une réforme entreprise et achevée en un moment dans l'histoire, mais un mouvement, un esprit qui porte en lui une force inepuisable de croissance, de renouvellement et d'approfondissement. La Ré-

(134) Max Boegner - Cours, VI, pag. 262. 
forme après avoir rendu possible et soutenu de tout son effort la formation de nations independentes, devait necessairement découvrir la sauvegarde de cette independance dans une société des nations garantissans à chacune le respect de ses droits essentiels. Elle continuera dans l'avenir, par fidélité aux grands principes de l'Évangile du Christ, a render la coopération des peuples dans un commun labeur pour fonder la vie internationale, dans tous les domaines, sur la reconnaissance de la valeur sacrée de la persone humaine et des exigences de la solidarité" (135).

7 - Os projetos de paz perpétua. Dele nos ocuparemos mais tarde (136).

\section{SEGUNDO PERIODO}

\section{O Direito Internacional depois de Grócio}

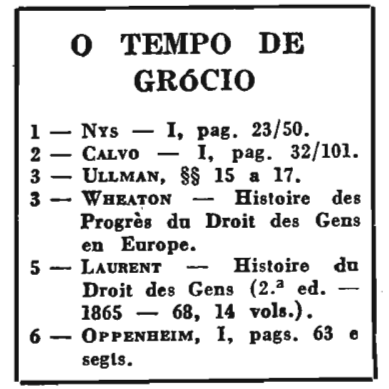
mando um verdadeiro Código ou consolidação, o DE JURE BELLI AC PACIS. Essa obra correspondia de tal forma ás necessidades do momento que foi considerada uma verdadeira lei. O panorama internacional do seu tempo foi a idéia inspiradora de Grócro.

E' por isso que Grócio é denominado "PAI Do DIREITO INTERNACIONAL".

(135) Jacques Dumas - Les Origines Chretien nés du pacifisme contemporain - (Paris-1914) - N. Werss - La Démocratie et le Protestantisme (Paris-1924).

(136) OPPENHEIM - I, § 42, n. 7, p. 61. 


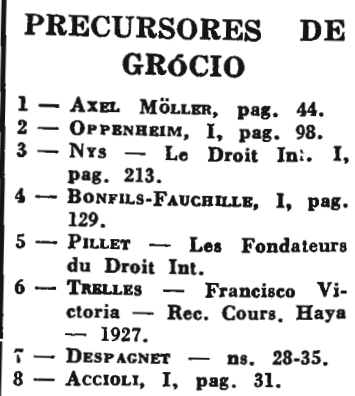

\section{HUGO GRÓCIO}

1 - Sylvio Gurger do Amaral. - Ensáio sobre a vida . obras de Huco Groot (Rio, 1903).

2 - WALKER, History, pag. 284 a 329.

3 - Van Der Vlugt - L'oen. vre de Groius et son influence sur to developpe. ment du Droit International (Cours, 1925, II pag. 399).

4 - Kosters - Some less Works of Hugo Grotius (Bib. Visseriana).

Grócio teve precursores: Machra. vel (Calvo, 21), Legnano, Belli, Victoria (137), Ayala (138), Suarez (139) e GeNTILI (1552-1608), italiano, professor em Oxford. O livro de Gentrili, DE JURE BELLI, foi mesmo o modelo de Grócio, mas, conquanto Grócio muito deva a Gentili, foi o maior e com justiça foi cognominado "Pai do Direito Internacional" (OPPENHeIM - VAN DER Vlugt - L'Oeuvre de Grotius - Cours - $1925(140)$.

O grande jurisconsulto holandês nasceu em Delft, em 1583. Desde a mais tenra idade mostrou grande talento e amor ao estudo, sendo considerado um menino prodigio. Começou a estudar Direito em Leyden aos 11 anos e aos 15 era doutor em Leis por Orleans. Em 1618, foi condenado á prisão perpétua. Em 1621, fugiu. Em 1634, entrou para o serviço da Suécia, tornando-se Ministro sueco em Paris. Morreu em 1645, em Rostock.

Em 1609, escreveu o "Mare Liberum" Em 1625, publicou o "De Jure Belli". Este livro imortal, considerado como o mais importante depois da Bíblia, é o fundamento de todo o desenvolvimento posterior do Direito das Gentes (141).

(137) J. BARThÉLEMy - Les Fondateurs, p. 1/36 - Victoria foi quem primeiro ensinou o Direito Internacional num estabelecimento de instrução (Brown ScotT - La Découverte de l'Amérique et le Droit des Gens) - R. D. I., IV, p. 38.

(138) Nys, Rev. Dr. Int. et de Lég. Comparée (1913). p. 280$)$.

(139) Verdross o considera superior a Victoria (Cours, t. 30,

(140) Afirmação contestada por A. Cavaglieri (Cours, p. 27).

(141) O "De Jure Belli ac Pacis" é indubitavelmente uma obra que traz o cunho do gênio, rica de pensamentos profundos, originais, luminosos, e ornada de larga erudição" (LAFAyeTTE, \& 21). Continua até hoje a ser invocado como uma autoridade digna de respeito e é um repositório de idéias e principios sãos. (LAFAYETTE, § 21). "The whole development of the whole Law of Nations as well as 
A sua intenção foi, a principio, escrever um livro sobre a guerra (142) e não um tratado completo de Direito Internacional, impressionado com as crueldades praticadas nas lutas do seu tempo (Vide "Revista da Faculdade" - "Submarinos de Guerra" - tese do dr. Braz de Souza Arruda). As suas investigações o levaram muito longe e publicou um verdadeiro tratado de Direito Internacional (143). Não só Grócro, mas os grandes internacionalistas tambem contribuem para a formação do Direito Internacional (144).

\section{DOUTRINA DE} GR6CIO

Pradier FodÉrÉ (Traité de Droit International Public, 1885) critica aqueles que citam Grócıo sem o terem lido, entre eles Calvo. Adverte que Grócro dá uma divisão, não do Direito Internacional, mas sim do Direito em geral. Ei-la:

DIREITO $\left\{\begin{array}{l}\text { Natural } \\ \text { Voluntário }\end{array}\left\{\begin{array}{l}\text { Humano } \\ \text { Divino }\end{array}\left\{\begin{array}{l}\text { Civil } \\ \text { Mais restricto } \\ \text { que civil } \\ \text { Mais estenso } \\ \text { que o civil }\end{array}\right.\right.\right.$

o Direito humano, mais estenso que o civil, é que é o Direito das Gentes, Grócio distingue perfeitamente o Direito das Gentes do Direito Natural Puro, firmando que ele se forma não só dos principios do Direito Natural mas tambem pelo consentimento geral das naçöes, constatado pelos seus usos (V. tambem Grotius, Le Droit de la Guerre et de la Paix, trad. de Fodéré, 1867, liv. I, \& X, I pag. 75, l. I e § XIV, 1. I. pag. 91).

that of the science of the Law of Nations, takes root from this for ever famous book" (OPPENHEIM, I, \& 53, p. 101). O monumental trabalho de Grócro, publicado em mais de 50 edições latinas, e traduzido em várias linguas, tornou-se "the foundation of the Science of International law of the whole of modern time" - (A. MöLLER, pag. 45).

(142) LAFayetTe, § 20.

(143) "At the end of Seventeenth century the civilised States considered themselves bound by a Law Nations, the rules of which were to a great extend the rules of Grotius" (OPPENHEIM I, pg. 64).

(144) LAFAYETte. $\$ 18$. 
o que é certo é que Grócio admitia a existência ao lado do Direito Natural de um Direito voluntário, determinado pelo consenso dos Estados ao qual denominava Direito das Gentes.

As particularidades sobre a doutrina grociana podem obter-se lendo-se o seu "De Jure Belli ac Pacis", traduzido por James Brown Scott (Oxford, 1925).

Grócio funda o Direito das Gentes, tendo por base a convicção da unidade do genero humano (Proleg., $§ 24$ ), seguindo as pegadas de Soto, Victoria, Suarez e Covarruvias. Victoria já dissera que um Estado não é senão uma parte do mundo inteiro (De Potestate Civile).

A opinião de SuAREz pode ser vista na maravilhosa obra de VANDerpol (La Doctrine Scolastique du Droit de Guerre, pag. 506), "Omni gens una sumus" dizia já Claudrano, De Stilic.

Z O U C H existência do Direito Internacional natural, que o Direito Internacional costumeiro era mais importante. O seu trabalho escrito em 1650 pode ser considerado o primeiro manual positivo de Direito Internacional.

Foi ele tambem o primeiro a usar das expressões - JUS INTER GENTES (145). Grócio denominava a sua ciência JUS GENTIUM, e devido á sua influência originou-se a expressão DIREITO DAS GENTES.

Mais tarde BENTHAM adotaria a expressão DIREITO INTERNACIONAL (International Law).
Da influência contrária de Grócio dando preferência ao Direito Natural sobre o Positivo e de Zouch, preferindo o Positivo ao Natural, originam-se as três escolas de Direito Internacional: NATURALISTA, POSITIVA e GROCIANA.

E' o que salienta Bourquin (Droit Int. de la Paix, Cours, 35, p. 18). Mostra ele como os internacionalistas a partir do sec. 17 , com

(145) Victoria, segundo Axel Möller, 47, Hershey, 89, Rivier, I, p. 6, usou da expressão antes de Zouch. 
Zouch, seguido no século XVIII por Bynkfrshoecis, Moser e MARTENS, estendem dia a dia o papel de D. Voluntário, em detrimento do Natural. O positivismo vai cada vez mais ganhando terreno, atenuando-se progressivamente a influência do D. Natural.

\section{OS NATURALISTAS}

1 - Axel Möller, pag. 46.

2 - Oppenheim, I, p. 104. aplicado ás nações. Os principais são: Pufendorf, o fundador da Escola; Thomasius, Hutcheson, Rutherford, Barbeyrac e BurlaMAQUI.

os POSITIVISTAS

1 - LaFayetTe, \& 23.

2 - AXEL MöLLER, p. 47.

3 - OP PENheim, I, pag. 105.

Os positivistas sustentam que o Direito Internacional positivo, origina ado dos usos e costumes e dos tratados, modos por que se manifesta o consentimento comum dos Estados que compõem a Família das Nações, é muito mais importante do que o Direito Internacional Natural. O Direito Internacional é uma criação histórica, um produto das necessidades práticas e da comunhão de idéias, interesses e cultura das nações e revelado por usos, costumes, tradições e fatos.

Rachel e Textor escreveram no século XVII, quando a escola começou a ter importância. Temos, no século XVIII, BYNIKErshoEck, Moser, considerado por LAFAYETTE o verdadeiro fundador da escola, e Martens. De todos eles o mais positivo é Bynkershoeck, que baseia o Direito Internacional no consentimento comum.

Alguns positivistas negam mesmo a existência do Direito Natural.

O objeto da ciência do Direito é o Direito Positivo. Seu papel é dizer o Direito em vigor, determiná-lo, explicá-lo e ordená-lo sistematicamente. Pouco importa que, de outro aspeto muito distinto concorra, de acôrdo com outras ciências, para sua reforma por meio de uma apreciação crítica.

E' necessario contudo separar a norma em vigor de vâs aspirações da conciência social ou da doutrina. 
O Positivismo verdadeiro não admite o Direito Internacional Natural (146). Diz muito bem, o preclaro OppenheIm: "Weknow now a days that a Law of Nature does not exist. Just as the so called natural philosophy had to give way to real natural science, so the Law of Nature had to give way to jurisprudence, or the philosophy of the positive Law. Only a positive Law of Nations can be a branch of the science of law" (I, p. 116).

OS GROCIANOS

1 - Axer MöLleR, p. 47. 2 - Op penheim, pag. 107.
Os grocianos dão importância igual ao Direito Internacional Natural e ao Positivo. Os principais são WolfF, VATTEL e a maioria dos escritores fran-

ceses. Entre nós Lafayette, § 15.

\section{OBRAS PRINCI- \\ PAIS DOS POSI- TIVISTAS}

A primeira obra verdadeiramente positiva de Direito Internacional foi a de Hartmann (1874). A segunda, a de Hiall (147). Depois, a de Oppenheim, o mais insigne representante da nossa es-

cola. Além deles, Bulmering, Taylor, Wilson, Maxey, Hershey, Liszt, Axel Möller, Ullmann e Stockton podem ser considerados positivistas.

(146) Fala-se hoje muito em renascença do Direito Natural. Contudo, no Brasil, como diz muito bem Clovis Bevilaqua (Estudos Jurídicos, pag. 170) o conjunto dos espíritos seletos, que se têm entregue ás investigações do problema juridico, em sua feição filosófica, não obstante dissentimentso nas concepções fundamentais e no método, é avesso ao Direito Natural. Realmente, Sylvio Romero repele a concepção do Direito Natural, como já anteriormente a repelira Tobias Barreto. Do mesmo modo, Fausto Cardoso, aplicando o haeckelismo ao Direito, Laurindo Leão e Pedro Lessa, no seu livro Estudos de Filosofia do Direito.

O grande e saudoso Pedro Lessa encontra no método positivo os elementos necessários, á construção da ciência do Direito.

Si assim é entre nós, na própria Alemanha o idealismo critico de Hiegel, retemperado pela experiência, esclarecido pela História e pela legislação comparada, opõe embargos ao Direito Natural.

Apontemos Kohler e Berolzhermer. Não pode realmente haver um direito universal, imutavel. Mesmo não podemos falar em Direito Natural, no sentido de Stammler, isto é, Direito Natural de conteudo variavel. O Direito varia de acôrdo com as necessidades sociais. Se para Berolzheimer o Direito é eminentemente cultural, é um dos elementos essenciais da civilização e varía com ela.

(147) " one of the best books on the Law of Nations that have ever been written" (OPPENHEIM, I, § 59). 
DEPOIS DO APARECIMENTO DO "DE JURE BELLI"
Considerados os fatores que influiram no espirito de Grócro, estudemos a seguinte época do Direito Internacional, depois do aparecimento de sua obra, ern 1625. No tempo de Grócio, achava-se a

Europa dividida em um grande número de Estados, com contínuas relações comerciais.

Foi indispensavel o aparecimento de regras de ação que regulassem as relações reciprocas desses povos. Foi para reger as relações internacionais dos Estados que apareceu o Direito das Gentes. Grócro, como cristão, inspirou-se, quando fundou o Direito Internacional, na moral cristã, e porisso é ainda a moral da humanidade culta, a moral do Direito das Gentes.

E' considerado justo em Direito Internacional o que é justo em face dos principios cristãos. A violação de principios cristãos é a violação de principios do Direito Internacional.

A história do Direito Internacional depois de Grócio pode dividir-se nos seguintes periodos: 1648-1721, 1721-1789, 1789-1815, 18151856, 1856-1874, 1874-1899, 1899-1914, 1914-1918, 1918 até hoje.

1648-1721 - Começa este período com a PAZ DE WESTPHALIA (148). As reuniões de Munster (católicos) e Osnabruck (protestantes) constituem os primeiros exemplos de Congressos reunidos para resolver questões internacionais pelo consentimento comum dos povos.

Foi o Tratado de Westphalia que primeiro reconheceu o sistema do Estado Nacional e das soberanias nacionais independentes.

Como ensina BRYcE, a história moderna caracteriza-se pelo nascimento dos Estados nacionais com o desenvolvimento correlativo do sentimento patriótico, a expansão do capitalismo e o imperialismo contemporâneo.

Nos grupos primitivos, o vínculo que unia os homens era o sangue, dominando o instinto da grei. Realmente, o homem é fundamentalmente social. Nunca viveu nem poderia viver isoladamente. Dai unirem-se os homens como as abelhas e as formigas em grupos, e dai tambem a solidariedade e o instinto da grei, a que se refere Troterer (Instinct of the Herd in Peace and War).

Em seguida ás tribus nômades, vincularam-se os homens ao território, e isto muito recentemente. Daí transformarem-se as relaçóes pessoais e de consaguinidade das tribus em políticas e territoriais, nas cidades.

14.

(148) Accioli, § 57 - Axel Möller, p. 16 - Cruchaga, I, p. 
Estas cidades foram absorvidas por impérios patriarcais. Apontaremos o antigo Egito, formado pelas numerosas cidades do vale do Nilo; os impérios Babilônico, Assírio e Persa.

Os Estados nacionais poderiam formar-se como um produto da antiguidade, consequência das cidades antigas, se não fosse a absorção destas pelos impérios patriarcais. 0 . sistema da unidade do mundo culminou com o Império Romano. Dentro, contudo, dos Impérios patriarcais, dentro do Império Romano existiam culturas particulares, permaneciam nacionalidades com ideais e pontos de vista peculiares.

O espirito de Roma foi herdado pela Europa e vive ainda hoje nos povos mais civilizados do continente europeu.

A tendência para o universalismo atravessou a Idade Média e é sintetizado por DANTE no "DE MONARCHIA" (149).

A Igreja herdou o espírito de unidade da Roma imperial. A Igreja é na Idade Média um grande Estado internacional, dominando no religioso e no plano mental.

"A ciência européia estava unida pela teologia e pela educação, e a lingua latina era na Idade Média a língua da política, dos negócios e do saber.

Formou-se assim pela religião uma comunhão da fé, um Sacro Império, tendendo-se para um grande movimento mundial unitarista.

Coincidem então os limites de Roma com os do Império da Cristandade. E' o que expõe maravilhosamente JAMES Bryce (150).

Surge em seguida a nova éra, a dos Estados Nacionais, formando-se uma Familia de Nações, independentes e soberanas, base para o desenvolvimento do Direito das Gentes. Este surgiu dos Estados Soberanos, esta nova éra não é produto exclusivo da Renascença ou da Reforma, mas sim consequência na sua maior parte, como ensinam os modernos historiadores, da expansão da Europa, das descobertas, do desenvolvimento do capitalismo. Muito mais contribuiu o contato das culturas e a curiosidade intelectual estimulada pelas descobertas para o progresso intelectual do que a ressureição da antiga cultura.

Não queremos negar a importância extraordinária da Reforma, mas sim salientar que não nos devemos ater a fatores particulares, desprezando a complexidade dos pontos de vista gerais.

(149) Dante apenas tinha a paixão de sua cidade e a concepção do Império. Nem ele e nem Machiavel previram ou prepararam a unidade italiana (NITTi, Dém. I., p. 91).

(150) The Holy Roman Empire, pags. 90 e 91. 
E' de notar que do sistema feudal não poderia surgir uma ordem internacional.

Com a formação dos Estados independentes e soberanos, desenvolveu-se o nacionalismo, surgiram as literaturas particulares dos Estados. A' Europa feudal e imperial sucedeu uma Europa fundamentalmente nacionalista.

Como salientaremos mais tarde, o nacionalismo bem entendido não é contudo incompativel com a cooperação internacional (151).

RESULTADO DO

CONGRESSO

1 - Axel. MölleR, p. 16.

2 - Op Penteim, pag. 65 .
1) - A Suissa torna-se independente;

2) - Os 332 Estados do Império Germanico formam uma confederação, tendo o imperador por chefe;

3) - Desaparece o princípio da unidade do mundo;

4) - Surge o principio do equilibrio europeu;

5) - Os Estados protestantes e católicos são tratados no mesmo pé de igualdade.

A politica de conquista de LUIZ XIV tem como consequência numerosas guerras.

Neste periodo, o "REI SOL" viola o Direito Internacional a todo - momento, mas sempre acha um meio de se desculpar e nunca confessa a violação. Tratados importantes:

1) - Paz dos Pyreneus (1659);

2) - Paz de Aix-la-Chapelle (1668);

3) - Paz de Nymegue;

4) - Paz de Ryswick (1697);

5) - Paz de Utrecht (1713), e as de Rastad e Baden, de 1714, terminando a guerra da sucessão da Espanha. Além destes tratados, celebrados em virtude de guerras com a França, outros foram concluidos. Entre eles:

1) - Paz de Roeskild (1658);

2) - Oliva (1660);

3) - Copenhague (1660);

4) - Kardis (1661);

(151) Аввотт, W. C., The Expansion of Europe; BRyce, JAmes, The Holy Roman Empire; Grenrer, A., The Roman Spirit: MAcLeod, W. C., The Origins of the State; Pillsbury, W. B., The Psychology of Nationality and Internationalism; Sellery, G. C., and Krey, A. C., Medieval Foundations of Western Civilization; Smirh, P., The Age of the Reformation; Trotter, E., Instinct of the Herd in Peace and War; ZimmerN, A. C., Nationaly and Governement. 
5) - Breda (1667);

6) - Carlowitz;

7) - Nystadt (1721), entre a Rússia e a Suécia (a Rússia entra para a Família das Nações).

Depois de 1721, ha grande progresso do Direito Internacional, principalmente em matéria de visita, bloqueio e liberdade dos mares. A doutrina do equilíbrio europeu é solenemente proclamada (Paz de Utrecht).

1721-1789 - Distingue-se pela rivalidade entre a Austria e a Prússia. Paz de AIX-LA-CHAPELle (1748). Paz de Hubertsburgo. Paz de Versailles (1783), Partilha da Polônia (1772, 1793 e 1795). A Prússia torna-se grande potência. E' geral nessa época a influência de Machiavel.: Primeira neutralidade armada (152). A América do Norte torna-se grande potência e entra para a Familia das Nações, onde representa papel salientissimo.

1789-1815 - 0 período da revolução francesa e das guerras na- poleônicas foi de desrespeito constante ás regras do Direito das Gentes.

O povo francês, oprimido pelos seus senhores, tinha chegado ao desespero. O luxo nababesco da Côrte (153), a imoralidade administrativa, a venalidade dos cargos, reduziam o povo á escravidão. Os camponeses tinham chegado ao extremo da pobreza. Esse estado de penúria popular vinha já dos tempos de Luiz XIV (154), cuja morte causou desusada alegria no povo (Saint Simon).

0 regimen do bel prazer do rei, no tempo de LUIZ XV, política feita de egoismo e estupidez, levou D'ARGENSon a declarar que a côrte era o túmulo da nação (155) e reduziu o povo á fome e á desesperança. As coisas culminaram no tempo de LUIZ XVI, o rei perjuro, fujão e desrespeitador das leis. 0 cansaço do absolutismo despertou o espirito crítico. VAuBAN ataca a desigualdade em matéria de impostos; Locke proclama a soberania do povo.

(152) AXel MöLler, p. 17; - ScotT - The Armed Neutralities of 1780 and 1800 (Washington, 1918).

(153) Malet, L'Époque Contemporaine, p. 5 - Os reis da França fazem-nos lembrar os que, segundo os Santos Padres, Deus envia para castigo dos povos (Bernardes, os ultimos fins do homem, MDCCXVIII, pag. 250-1). Não atino contudo com os pecados do infeliz povo francês. . .

(154) "Peu d'hommes ont fait plus de mal à la France que Louis XIV (Nitti, Dém. I, p. 91). A lenda, como explica NitTI, muitas vezes endeusa reis como David e Salomão (Dém., I, p. 90) e cria heroes como Arminião (Id. p. 91).

(155) MaLet, cit. pag. 380, Les Temps modernes. 
Os economistas e os filósofos continuaram a demolição do regimem. De um lado, Quesnay; de outro, Mostesquieu e Voltaine. Vem a Encyclopedia, e Voltarke, descortinando o panorama de seu tempo, exclama: "Tout ce que je vois, jette les semences d'une révolution qui arrivera immanquablement". Causas análogas produziram a revolução russa (156). Já é tempo de rehabilitar os revolucionários franceses, e principalmente MARAT.

Feita a revolução, a França luta 10 anos contra toda a Europa (abril 1792 - março 1802).

A Const. de 1791 interdizia a guerra de conquista, e a Convenção resolveu, em 1792, fazer uma proclamação dos direitos das nações. Contudo, atacada por todos os lados, reagiu. As causas das guerras da revolução foram:

1) - a Prússia e a Austria, aliadas a Luiz XVI, pretendiam ficar com a Flandres e a Alsácia;

2) - temor de que as idéias revolucionárias se espalhassem pela Europa;

3) - desejo dos revolucionários de espalharem os principios da revolução. Em suas lutas, finalmente, a França seguiu a política exterior da monarquia, isto $\dot{e}$, a dos limites naturais (157).

Finalmente a revolução cai nas mãos de NAPOLEÃO I. As origens das guerras napoleônicas foram:

1) - desejo por parte dos outros Estados de arrancar as conquistas da França, engrandecida até o Rheno;

2) - atacar e abafar os principios revolucionários, restabelecendo a realeza. Napoleão era homem de poucos escrúpulos. Criava e suprimia Estados, violando os princípios do Direito Internacional (158). E' uma época de desrespeito ao Direito das Gentes.

Em 1793, a Inglaterra e a Rússia interditaram os portos franceses, desejando vencer a França pela fome.

Em 1800 (dec. Berlim), Napoleão proclama o bloqueio continental. A Inglaterra responde com o bloqueio dos portos franceses.

As práticas bélicas eram bem crueis. Napoleão abandonava seus soldados doentes e feridos, exceto na Campanha da Rússia. Contudo Percy socorria já em 1791 os feridos, e Larrey introduz os ambulatórios volantes.

(156) Princesse Dolgonouky, La Russie avant la Débâcle.

(157) Foreign Affairs - $1-1930$.

(158) NitTi, Dém., I, p. 153. 
As consequências das guerras napoleônicas foram tristes para a França; aumentaram as doenças e epidemias (de tifo em 1813) e a própria estatura do povo francês diminuiu, como demonstram as estatísticas (159).

\section{CONGRESSO DE \\ VIENNA (1814 \\ E. 1815)}

O Congresso de Vienna quis reorganizar a Europa, e discutiu tambem questões internacionais.

1815-1856 - Começa este período com a SANTA ALIANÇA (160) formada

em 30 de Setembro de 1815, por iniciativa de Alexandre I da Rússia, logo depois da conclusão do Congresso de Vienna.

Era a SANTA ALIANÇA organizada para a defesa dos princípios dinásticos e da legitimidade.

Constituida entre soberanos, não era uma aliança entre Estados. O Papa e o Sultão não tomaram parte nela, bem como o rei da Inglaterra, pessoalmente.

A Grécia e a Bélgica. Napoleão III adota o princípio das nacionalidades e torna-se Imperador da França. Guerra da Criméa, terminada em 30 de março de 1856 pelo tratado de Paris. A Tur. quia entra então para o Concerto Europeu. Declaração de Paris (16 de ábril de 1856) (161).

1856-1874 - 0 princípio das nacionalidades continua triunfante. Unifica-se a Alemanha. A Austria torna-se monarquía dual, e ha a unificação da Itália (V. Marcel Moye). Estados Unidos. Leis de Guerra (1863). Convenção de Genebra (1864). Declaração de S. Petersburgo (1868). Conferência de Londres (1871). Conferência de Bruxelas (1874).

1874-1899 - Princípio das nacionalidades triunfantes (162).

1874-1899 — Em 1879, guerra Chile vs. Perú-Bolivia (Cruchaga I, 25). Em 1894 entre a China e o Japão, terminada pela paz de Simonoseki. Guerra dos Estados Unidos com a Espanha (1898). Independência de Cuba (Tratado de Paz de Paris, 1898). Imperialismo americano (163). Conferência de Berlim sobre o Congo 18841885. Conferência de Haya de 1899 (164), para a qual o Brasil foi

\footnotetext{
(159) Tchuriloff, For. Affairs; Kraehbiei, Nat. and War.

(160) P. Cresson, The Holly Alliance.

(161) Oppenheim, I, § 47; Axel Möller, pag. 22.

(162) OPPENHEIM, I, § 48. Accioli.

(163) Arruda, Rev. Fac. Dir., vol. XXIII, p. 180 e segts.;

(164) Oppenheim I, § 49; AXel Möller, p. 25.
} 
convidado tendo deixado de comparecer. Tal abstenção tem sido acremente criticada, censurando-se a resolução do sr. Olintho de Magalhães, o Ministro que a tomou, defendido contudo pelo Ministro Rodrigo Octavio (A Renovação do Direito Internacional - 1928). 1899-1914 - Guerra sul-africana. Intervenção da China. Guerra russo-japonesa, terminada pela paz de Portsmouth (1905). Rivalidades entre a França e Alemanha em Marrocos. - Guerra italo-turca (1911). Intervenção americana no México (1914). Segunda Conferência de H'aya (1907) (165). Conferência Naval de Londres (166). Arbitramento (167).

1914-1918 - Em consequência do assassinato do arquiduque austríaco Francisco Fernando, em Serajevo (28 de junho de 1914) rompe a grande guerra (168).

Em 28 de julho de 1914, a Austria declara guerra á Sérvia. Em 4 de agosto, a Alemanha viola o território belga, e a Inglaterra declara guerra á Alemanha.

Em 30 de outubro de 1914, a Turquia une-se á Austria e á Alemanha, e a Bulgária faz o mesmo em 11 de outubro de 1915.

Combatem 26 aliados contra a Alemanha. Os principais são: GRã BRETANHA, FRANÇA, RUSSIA, BELGICA, SERVIA, e mais tarde, os ESTADOS UNIDOS e ITÁLIA.

A Alemanha começa a guerra, violando o território da Bélgica, atacando de frente todos os princípios do Direito das Gentes, universalmente aceitos. Esperavam os alemães que a história justificasse esses desrespeitos do Direito Internacional. Mas não, a humanidade se convenceria mais uma vez da lição da história do Direito das Gentes: - todo o povo que violar os principios do Direito Internacional será fatalmente vencido, esmagado, obrigado a submeter-se á vontade dos Estados membros da Familia das Nações, aos principios do Direito das Gentes, á moral Internacional (169).

Em 1915, a Alemanha começa a guerra submarina. Em 7 de Maio de 1915, dá-se o torpedeamento do "LUSITÂNIA", um dos crimes mais nefandos da história (Vide "Conferências patrióticas", "Revista da Faculdade", 1920).

(165) AXEL Möller, pag. 26.

(166) AXEL Möller, pg. 28.

(167) OPPENHEIM, I, § 50.

(168) Scотт - Diplomatic Documents Relating to the outbreak of the European War (Washington, 1916).

(169) Toda a violação do Direito Int. é fatal ao Estado que a pratica (Funk Brentano e Sorel. Precis - 1900, pag. 7 - V. T. R. Roxburgh. Rev. Am. Der. Int. $1920-$ La Sanción del Der. Int.). E' tambem a lição de Axel Möller, p. 57. 
Em 1916 e 1917, toma vulto e torna-se cada vez mais cruel a guerra submarina. A Alemanha procura espalhar o terror sobre a terra (Vide Conferências, "O crime e a loucura da Alemanha", "Revista da Faculdade", 1920).

Em 3 de fevereiro, a América do Norte rompe as relações com a Alemanha. Em 6 de abril, declara-lhe guerra.

Em março de 1917, a revolução russa impressiona os espiritos, e, finalmente, o govêrno bolchevike assina o Tratado de Brest Litowsk.

Em 1918, faz a Alemanha o supremo esfôrço, e em outubro principiam as negociações para a paz, que tem como resultado o armistício de 11 de novembro.

Já haviam abandonado a luta os seus aliados: a Bulgária, (armistício de 29 de setembro de 1918), a Turquia (30 de outubro) e a Austria ( 3 de novembro).

Estava assim terminada a Grande Guerra. Começa então a nova época, iniciada em 1918 (170).

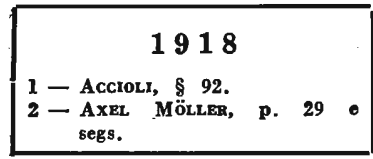

A conferência da paz abre-se em 18 de janeiro de 1919. Em maio, o Tratado de Paz com a Alemanha é apresentado aos seus plenipotenciários. Depois de algumas modificações, é assinado em

Versailles (28 de junho de 1919). O Tratado de Paz com a Austria é assinado em Saint Germain (10 de setembro de 1919).

As consequências desses tratados são bem conhecidas, e serão estudadas por nós, pormenorizadamente, mais tarde. A grande guerra foi a primeira luta em que interveiu toda a humanidade. Houve como uma unificação do mundo, e hoje todos os problemas técnicos e econêmicos assumem um caracter cosmopolita. Com essa unificação planetária iniciou-se um processo de nivelamento. As raças se mesclam, as culturas históricas desprendem-se de suas raizes para cair no mundo técnico econômico e num intelectualismo vazio. $O$ que hoje se generaliza é o superficial, o nulo, o indiferente. Domina a massa. Será um mal? Será um bem?

Ultimamente, três acontecimentos notaveis são de assinalar: Pacto Briand-Kellog (27 de agosto de 1928); o Tratado de Latrão (11 de fevereiro de 1929); e o Projęto de criação dos Estados Uni-

(170) Hanotaux, Histoire illustré de la Guerre de 1914; GARNER, International Lau and the World War, 1920; SHotwels, Economic and Social History of the World War, 1921. 
dos da Europa, sugerido por Briand, de que nos ocuparemos oportunamente.

\section{LIÇôES DE HISTó- RIA DO DIREITO INTERNACIONAI.}

Temos estudado assim, resumidamente, a história do Direito Internacional através dos tempos, desde a antiguidade até hoje. De nada serviria contudo o estudo dessa história si dela não tirássemos algumas lições para o futuro.

Oppenheim, o saudoso professor da Universidade de Cambridge, tira da História do Direito Internacional sete lições:

1) - A primeira e principal lição é que só é possivel a existência de um Direito Internacional existindo o equilíbrio, uma balança de poderes, entre os membros da Família das Nações. Si as potências não se poderem contrabalançar uma servindo de freio e contrapêso á outra, as normas juridicas não terão nenhuma fôrça, porque o Estado muito poderoso naturalmente procurará agir discricionariamente e desobedecer ao Direito. Como não existe e nunca poderá existir uma autoridade política central sobre os Estados soberanos, para sancionar as regras do Direito Internacional, só um equilíbrio de poderes pode impedir um membro da Familia das Nações de se tornar onipotente.

A história dos tempos de Luiz XIV e Napoleão I mostra claramente a verdade desses princípios. E ela é particulamente importante em tempo de guerra. Quando pequenos Estados ou algumas grandes potências estão em guerra, ha o temor dos beligerantes de que Estados neutros intervenham e possam evitar a violação de regras fundamentais do Direito Internacional relativas ao modo de guerrear e ás relações entre beligerantes e neutros. Mas quando, como durante a Grande Guerra, as grandes potências estão divididas em dois campos que se hostilizam e os Estados neutros constituem insignificantes forças, não podem restringir a liberdade de ação dos beligerantes $e$ compeli-los a conduzir a guerra dentro dos limites do Direito Internacional.

A existência de uma Liga das Nações não significa a desnecessidade de um equilíbrio de poderes, porque um Estado onipotente poderá desrespeitá-la.

Esta é a primeira lição da história do Direito Internacional extraida por OPPENHEIM.

Escritores de grande autoridade são contrários a essa doutrina da balança de poderes, como por exemplo BuIMERINQ.

H. G. Wells (Faillite de la Démocratie pag. 57) combate o internacionalismo e se confessa adepto do cosmopolitismo. Diz ele que um Estado soberano é uma porção 
da humanidade que se opõe ao resto dela (pag. 224). Examinaremos mais tarde os ideais de WeLLS e de RaLSTON (Droit International de la Démocratie).

Nada podemos profetizar sobre a transformação futura do Direito Internacional. Já disse BrXce que a história nos ensina que os movimentos intelectuais e sentimentais não podem ser previstos. Estudamos, portanto, o que é o Direito Internacional, o que existe na realidade, criticamos o que nos parece não corresponder ás necessidades sociais e procuramos concorrer para o progresso da humanidade, isto é, para a felicidade harmônica de todos os membros da Família Humana.

2) - A segunda lição extraída por OpPEnheim da história do Direito Internacional é que este só poderá progredir quando a política internacional, especialmente a intervenção, tiver por base o interesse real dos Estados.

As guerras dinásticas pertencem ao passado, bem como as intervençôes a favor da legitimidade. Não é de temer nem de desejar que ainda ocorram no futuro. Mas se ocorrerem, impedirão o desenvolvimento do Direito das Gentes, no futuro, como fizeram no passado.

3) - o progresso do Direito Internacional está intimamente ligado á vitória do Direito Constitucional, sobre o Direito autocrático, ou, o que é a mesma coisa, á vitória da $D e-$ mocracia sobre a Autocracia. O Govêrno autocrático não sendo o responsavel perante a nação que domina, tem uma tendência em basear a politica externa do Estado, como a política interna, na fôrça bruta e na intriga; ao passo que o Govêrno Constitucional baseia, em regra, a política externa e interna, em última análise, no consentimento dos governados.

$\mathrm{E}$ conquanto não seja certo que a democracia sempre e em toda a parte defendesse a Justiça e o Direito em matéria internacional, o que é indisputavel é que sempre excluiu a política pessoal de engrandecimento e de expansão territorial insaciavel que no passado foi a causa de numerosas guerras.

4) - A quarta lição é que o princípio da nacionalidade é de tal fôrça que é infrutífero tentar impedir a sua vitória. Quando uma comunhão de alguns milhões de indivíduos ligados pelo mesmo sangue, língua e interesses, torna-se tão poderosa que acha necessário formar um Estado próprio, no qual possam viver de acôrdo com os seus ideais e construir uma civilização nacional, conseguirão, certamente, formar um Estado, cêdo ou tarde.

0 que a política internacional pode e deve fazer é firmar a regra de que as minorias de individuos de outra raça não deverão ficar fora da lei, mas devem ser tratadas em condição de igualdade com a maioria. 
Estados compreendendo a população de várias nacionalidades podem existir e existiram sempre, como ha vários exemplos.

5) - A quinta lição é que todo progresso no desenvolvimento do Direito Internacional só é possivel em tempo oportuno. Conquanto possa desejar - si o tempo em que a guerra desapareça inteiramente, é impossivel ver-se este ideal realizado - na nossa época.

A necessidade primordial da paz perpétua é que a superfície do globo esteja dividida entre Estados do mesmo gráu de civilização, e que as idéias morais das classes governantes em todos os Estados do mundo sofram tamanha alteração e desenvolvimento progressivo, que criam a convicção de que as decisões arbitrais e as das Cêrtes de Justiça sejam os únicos meios adequados para a solução dos conflitos internacionais.

A paz perpétua é um ideal, e na significação própria de ideal envolve a convicção de impossibilidade de sua realização no presente, conquanto seja um dever trabalhar constantemente por esse desideratum.

A Corte Permanente de Arbitramento de Haya, estabelecida pela Conferência de Paz de 1899, é uma instituição que nos pode levar perto da realização deste escopo. E a codificação de parte do Direito Internacional seguindo a codificação de regras tratando da guerra terrestre, virão em tempo oportuno, e serão a base de um intercurso internacional mais firme e mais eficiente do que nos tempos anteriores.

6) - A sexta lição é que o progresso do Direito Internacional depende precipuamente da prevalência da Escola Juridica sobre a Escola Diplomática do Direito Internacional.

A escola juridica deseja que o Direito Internacional se desenvolva, mais ou menos, nas linhas do Direito Interno dos Estados. Deseja a codificação de regras firmes, decisivas e inequivocas de Direito das Gentes, e pugna pelo estabelecimento de Tribunais Internacionais para a administração da Justiça Internacional.

A Escola Diplomática, de outro lado, considera o Direito Internacional como sendo, e prefere que continue a ser, um corpo de princípios elásticos, em vez de se tornar um conjunto de regras precisas.

A Escola Diplomática se opõe ao estabelecimento de Tribunais Internacionais, porque considera a solução diplomática das questões internacionais, ou ainda o arbitramento, preferiveis á administração de Justiça por Tribunais Internacionais compostos de Juizes efetivos e permanentemente designados. Não ha contudo dúvida alguma sobre a urgência de criação de Tribunais Internacionais, e não se pode discutir que as regras do Direito das Gentes demandam agora uma interpretação autorizada e- 
devem ser administradas de uma forma que só é possivel por intermédio das Côrte Internacionais de Justiça (171).

7) - A sétima e última lição é que o progresso do Direito Internacional depende acima de tudo do gráu da moralidade pública, de um lado, e de outro, dos interesses econômicos. Quanto mais alto for o standard da moralidade pública, tanto mais progredirá o Direito Internacional. $\mathrm{E}$ quanto mais importante for o desenvolvimento dos interesses econômicos, tanto mais se desenvolverá.

Encarado de um certo ponto de vista o Direito Internacional é, como o Direito Interno, um produto da moral e de fatores econêmicos, e ao mesmo tempo a base para um desenvolvimento favoravel da moral e dos interesses econômicos (ver "Revista da Faculdade", "O interesse economico", vol. XXI).

Sendo isto um fato indisputavel, podemos afirmar, sem medo de êrro, que um progresso incomensuravel está reservado ao Direito Internacional, pois tem fatores econômicos e morais eternos trabalhando indefessamente a seu favor.

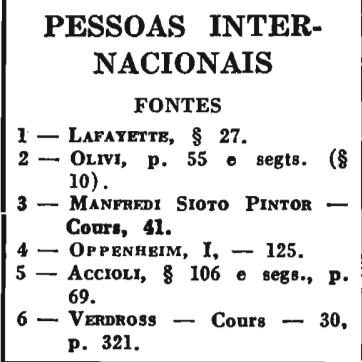

PESSOAS INTERNACIONAIS FONTES

1 - LAFAтETte, \& 27.

$2 \rightarrow$ Olrvi, p. 55 o segts. ( 8 10).

3 - Manfred Sioto Pintor Coure, 41.

4 - OPPENHEIM, I, - 125.

5 - Accrol., 8106 e segs., p. 69.

6 - Verdross - Cours - 30 p. 321 .

Direito Internacional, como já vimos, é o corpo de regras costumeiras e convencionais, que, por consentimento comum, são consideradas legalmente obrigatórias pelos Estados civilizados em suas relações reciprocas (172).

Se o Direito Internacional se funcla no consentimento comum dos Estados civilizados, esses é que são pessoas internacionais, como ensina OPPENHEIM.

Somente são pessoas de Direito Internacional os Estados soberanos, os únicos sujeitos de Direito das Gentes (Davis, 29 - OPPENHEIM, I, p. 125) (173).

Mas si todos os autores reconhecem que o Estado é a pessôa internacional por excelência (EPITÁcio, Cod., art. 2. ${ }^{\circ}-$ Hall, Int. Law, pg. 17 - Bonfils, pag. 77 - Accioli, $\S 108$ ) contudo discutem si é a única pessoa internacional.

(171) Contra: BATY, The Canons, § 7.․

(172) Oppenheim, Int. Law, I, pag. 3; Hall, Int. Law, pag. 1; Davis, pag. 1.

(173) Da posição internacional da Soc. das Nações nos ocuparemos mais tarde. 
Alguns positivistas mitigam este exclusivismo de afirmação, por exemplo, Diena. Realmente si só os Estados são pessoas internacionais, existem entes coletivos que oferecem certas afinidades com o Estado (domínios, insurgentes, etc.).

0 individuo fica sempre excluido (174).

Estas são afirmações de Burquin (Cours, XXV, p. 41). Diena diz que os Estados são e continuam sendo os verdadeiros formadores do Direito Internacional, conquanto se ha reconhecido e constatado que sujeitos de tal direito possam ser, além do Estado, outros entes.

Não se pode, contudo, excluir de modo absoluto, que na formação de novas normas do Direito Internacional possam concorrer tambem aqueles sujeitos de tal Direito que hajam surgido sem ter o caracter de Estado.

Diz Diena que, si até hoje só os Estados eram considerados pessoas de Direito Internacional, seria um grave êrro excluir a possibilidade de que em diversas condições históricas tambem outros entes, além do Estado, possam reputar-se sujeitos desse direito. Afirma ainda o notavel jurista italiano que, seja por tradição ou porque os principais sujeitos do Direito Internacional são sempre os Estados, as relações entre estes é que constituirão a matéria de que se ocupará em sua obra.

Ora, ninguem nega a possibilidade de que, em condições históricas diversas, outros entes se tornem pessoas de Direito Internacional. O que se afirma é que, atualmente, só os Estados soberanos é que são pessoas de Direito das Gentes.

\section{OS SOBERANOS E AGENTES DIPLO- MÁTICOS}

Heffter ( $\$ 48$ e segts.) sustenta que os soberanos e agentes diplomáticos são pessôas de Direito Internacional. Contra HefFter estão Oppenheim (Vol. I, pg. 126, etc.), Despagnet (87) e outros.

Ao estudarmos mais tarde a posição dos chefes de Estados, mostraremos que eles são apenas representantes de suas pátrias. Outros ainda dão ao individuo o caracter de pessôas internacionais. Para nós, nem os soberanos e agentes diplomáticos, nem os indivi-

(174) Alguns, contudo, sustentam que o homem é o único destinatário das normas constitutivas do Direito das Gentes, a única pessoa de direito internacional (A. DE LAPRADELLE, princ. lição II, pag. 20). Em que pese a opinião de Accioli e outros, não aceitamos a personalidade internacional do homem. 
duos, nem as corporações, nem os povos nômades ou depois da perda do território, são pessôas de Direito Internacional.

As nações e as minorias étnicas são protegidas pela Sociedade das Nações, mas em virtude de um Direito próprio de proteção. Sómente os Estados são pessôas de Direito Internacional.

OS CHEFES DE RELIGIõES

LORD Phillimore, filho ilustre do eminente Sir Robert Phillimore, sustenta, em curso na Academia de Direito Internacional de Hraya, que os Estados não são as únicas pessôas de Direito Internacional, e acrescenta: "Existem, com efeito, instituições, poderes de um outro gênero, os grandes chefes das Igrejas ou das religiōes organizadas, como Sua Santidade o Papa, Sua Beatitude o Patriarca de Constantinopla, e, para os Maometanos, o Khalifa. Os governos que têm entre os seus súditos um grande número de católicos romanos, cristãos, ortodoxos ou maometanos, devem entrar em relação com o poder religioso".

Refere-se ainda LoRd PHillimore ás companhias ou associações, para exploração de paises não europeus, e que, conquanto submetidas ao soberano do país, ao qual deviam sua incorporação, procediam para com outros como Estados semi-soberanos.

PESSOAS APARENTES DE DIREITO INTERNACIONAL

Ao lado dos Estados soberanos que são as pessôas reais de Direito Internacional, existem as Confederações e os insurgentes que poderemos considerar pessôas aparentes de Direito das Gentes (175).

Os Estados semi-soberanos não po-

ESTADOS SEMISOBERANOS dem ser sujeitos perfeitos e normais de Direito Internacional (OPPENHEIM, Int. Law, $1 . .^{\circ}, \S 65$, p. 127). Mas não podemos deixar de reconhecer-lhes, ao menos parcialmente, a qualidade de membros da Família das Nações.

Si nós observarmos atentamente o que se passa na realidade, veremos que eles gozam de certos direitos e exercem certas obrigações das pessôas internacionais.

Enviam e recebem agentes diplomáticos, ao menos cônsules; celebram tratados, principalmente comerciais; os seus monarcas

(175) OPPENHEIM, I, § 63. 
possuem privilégios que, de acôrdo com o Direito Internacional e as leis internas dos Estados, devem ser concedidos aos monarcas estrangeiros.

Basta isso para provar que os Estados semi-soberanos são de certo modo pessôas internacionais. Essa soberania é imperfeita, é anômala, mas tambem é existência de Estados sem plena soberania é outra anormalidade (176). A história ensina que os Estados semisoberanos não têm grande duração, porque, ou se tornam independentes ou desaparecem completamente, transformando-se em simples província de outros Estados.

Os Estados semi-soberanos (diz OPPENHEIM) constituem tal anormalidade, que se não pode dar uma regra fixa (hard-and-fast general rule) sobre eles, e ácerca de sua posição na Familia das Nações, porque tudo depende do caso especial.

Pode-se dizer unicamente que são mais ou menos dominados pelos Estados de que dependem. O seu caracter, contudo, de pessôas internacionais, aparece claramente quando são comparados com os Estados coloniais, que não têm nenhuma posição internacional.

Para o Direito Internacional os Estados coloniais nada mais são do que partes da metrópole, conquanto gozem mesmo de perfeito self government, podendo ser chamados, de certo modo, Estados.

o fator decisivo é que o seu governador é pago pela metrópole e o seu parlamento pode ser abolido e o da metrópole legislar diretamente para a sua colônia.

Esta distinção de Estados soberanos e semi-soberanos repousa na divisibilidade da soberania.

\section{OS ESTADOS E OS SEUS CARACTE- RÍSTICOS \\ Accioli - p. 77.}

O Estado pode ser definido, para os fins do Direito Internacional, como "uma reunião permanente de individuos que habitam em um território determinado, e obedecem ao mesmo govêrno, incumbido da administração da Justiça e da manutenção da ordem" (177).

(176) Baty - The Canons, \& $2 .^{\circ}$.

(177) Epitácio Pessoa, Cod. de Direito Internacional Fúblico, art. $10^{\circ}$; - Oppenheim, Int. Law, $10^{\circ}$; $\$ 64$; Davis, pag. 31 ; CruchaGa. 69; Merignhag, $10^{\circ} 115$; Despagnet, 88; Pomeroy, $\S 84756$; WoolsEy, $\S 36$; BLUNTSCHLI, $\S \S 17 / 27$; MARTENS, 16; WILdMAN, pag. 36; Phillimore, $\S \S 63 / 65$; Creasy, 93/99 e 112/118; Bonfils-FaUCHILle, I, § 160, pag. 223; Bevilaqua, 1.0, pag. 37; Accioli, § 119. 
São elementos caracteristicos do Estado:

1) - Povo, agregado de individuos que podem pertencer a raças diferentes, religiões diversas, etc.;

2) - Território, estensão do globo sobre que se fixou o povo, podendo ser grande ou pequena;

3) - Govêrno, uma ou mais pessoas representantes do povo, fazendo e aplicando leis, pois as comunhões anárquicas não constituem Estado;

4) - Govêrno soberano ou supremo poder dentro da comunhão social e independência exterior.

São estes para nós os elementos caracteristicos do Estado (178).

o POVO é o conjunto de indivíduos e familias de que se compõe a nação ("Nam populos vel notat totam civitatem, vel multitudinem subditorum" - PufEndorf, 7, 2, § 14). Ás vezes, é usado como sinônimo de nação. Conquanto Estado não seja rigorosamente sinônimo de nação, em Direito Internacional como tal é empregado (LAFAYETTE, $\S 27$; Bonfils-Fauchille, I, $\S 160$, nota 2 ; Baty, The Can. of Int. Law, $\S 10^{\circ}$ ). Heinecio (Elementa, J. N. et G., L. 2, § 108, nota a), seguido por HaLl $\left(\S 10^{\circ}\right)$ sustenta que pode a nação subsistir sem território, o que não podemos aceitar (LAFAyette, § 27, nota 2). Para nós, o território é um dos elementos essenciais do Estado. Além de Heinecio e Hall, numerosos outros escritores discordam de nossa afirmação. Entre eles, E. Cimbalr e A. Loria (Lo Stato secondo il diritto int. universale, Roma, 1891, p. 131, e Les Bases Économiques, p. 133). De idêntica opinião são Dorado Monterro (nota - A. Gumplovicz) e o célebre internacionalista Verdross (Cours, XXX, p. 334). Que existe Estado sem território é tambem opinião de KarL WolfF (Cours - Haya - 36) que sustenta pontos de vista muito originais em matéria internacional, afirmando mesmo que os bandos de salteadores podem formar Estado (p. 495).

A nosso favor Baty (The Canons, \& 30), AXel Möller (I, p. 73). Sobre as relações entre Estado e território, são interessantes as páginas escritas por Schaffle (Struttura del Corpo Sociale, trad. italiana na "Racolta delle più pregiate Opere moderne it. e straniere di ec. pol. diretta dal prof. G. Boccardo", 1884).

Sobre território vejam-se: Romano, Corso, pag. 13; ANzIцotтr, Corso, 159; Donato Donati, Stato e territorio (Riv. Dir. Inter. 1914 , p. 319 - magnífico).

(178) Enquanto permanece a associação humana com esses elementos, pelo princípio da continuidade do Estado, ele continúa idêntico a si mesmo (identidade do Estado). 
A soberania, conforme ensina Nippold, um dos mais célebres internacionalistas do mundo, no curso professado, em 1924, na Academia de Direito Internacional de Haya, não representa efetivamente em Direito Internacional senão a afirmação nas relações internacionais da personalidade livre do Estado, o reconhecimento do Estado como pessôa de Direito Internacional (179). Nada tem que ver com o Direito ou o princípio especial, mas simplesmente com o Estado enquanto pessôa.

\section{A SOBERANIA E' LI- MITADA E DIVI- SIVEL}

A soberanía é evidentemente limitada pelos direitos individuais, que repousam na conciência popular, desenvolvem-se historicamente pela conveniência, pela utilidade, pelo consentimento comum dos membros da comunhão social.

Isto na esfera do Direito Interno dos Estados. Na internacional a soberania de um Estado é claramente limitada pela dos outrós, como na esfera individual a capacidade de um indivíduo é limitada pela dos outros.

Nunca houve matéria tão discutida como a da soberania. Diz com felicidade OpPENHEIM: "It is an indisputable fact that this conception, from the moment when it was introduced in to polictical science until the present day, never had, a meaning which was universally aggreed upon".

Este termo variou muito através dos tempos em suas acepções. Merriam, "History of Sovereignty, since Rousseau", resumido por OPPENherm (I, §67, pag. 129), dá o conceito da soberania em diferentes épocas. Não discutiremos a teoria da divisibilidade ou indivisibilidade da soberania. O termo soberania foi introduzido por Bodrs, que sustentava a sua ilimitabilidade. Contudo, mesmo Bodin reconhecia que ela é limitada por Deus e pelo Direito da Natureza (De Rep.) Além de Bodrn foi Hobres (De Civil), para quem a soberania é onipotência. Para Pufendorf já a soberania pode ser constitucionalmente limitada (De Jure Naturæ et Gentium, VII, cap. 6, $\S \S$ 1-18).

O exemplo dos numerosos Estados plenamente e de outros só em parte soberanos do Império Germânico é que levou os escritores ao reconhecimento da divisibilidade da soberania. São os fatos impondo-se ás doutrinas de gabinete. 0 segundo exemplo foi o da Federação americana. Contudo, Rousseau ainda continua a susten-

(179) V. T. BATY - The Canons, $\S 4$ e 5; e Lutler and MACСову - Dev. pag. 7. 
tar a indivisibilidade da soberania no seu Contrat Social (1762). A concepção de Rousseau é a de HobBes, contudo para ele a soberania é do povo que não a pode alienar. Dai a doutrina da soberania, ilimitada, indivisivel e inalienavel. No século XIX, aparece na prática mais claramente a divisibilidade da soberania com o exemplo suisso (Constituição Suissa, art. $1^{\circ}$ ), germânico, etc. A doutrina da soberania concorrente da união e dos Estados foi defendida no $\mathrm{Fe}$ deralist, na America do Norte, e na Alemanha por WAItz. Não atacaremos nem defenderemos Waitz ou Calhoun, não citaremos o Federalista, de Hamilton Madison e Jay, apenas observaremos os fatos. Lógicos ou não, e racionais ou não, vejamos os fatos.

Os fatos não são feitos pelas teorias, mas estas é que nascem dos fatos. Os fatos não devem submeter-se ás teorias, mas estas $\dot{c}$ que devem se submeter aos fatos. Com Oppenherm observaremos o que se passa na realidade.

Como vimos ha povos semi-soberanos, que constituem verdadeiros Estados (180), logo a soberania é divisivel. A soberania $\dot{e}$ uma liberdade relativa, isto é, dentro dos quadros do Direito das Gentes. E portanto soberano não uma organização investida de um poder absoluto, mas aquela que não conhece como superior senão o próprio Direito Internacional (181).

Esta minha opinião ainda é fortificada pela Liga das Nações, que vem provar, mais uma vez, que a soberania é divisivel e limitada. Foi o que levou grandes jurisconsultos a dizerem que a Liga das Nações exigia um novo conceito de soberania (182).

DIENA (183) diz: alguns negaram que a soberania seja um elemento essencial para a existência do Estado, observando entre outras coisas que podem existir Estados membros de Estado Federal, sem que os primeiros possuam uma soberania verdadeira" própria, pois que estão subordinados ao ente coletivo.

Baseia-se tal opinião na doutrina de que a soberania não pode ser senão absoluta e completa, pois de outra maneira não existe. Mas essa doutrina encontra-se em contradição com os fatos dos quais resulta repetida e multiplicadamente que pode existir uma soberania dividida entre varios Estados ou uma soberania limitada; em concreto, uma soberania só nas relações internas e não nas relações internacionais.

(180) AXel Möller, I. p. 74.

(181) Verdross, Cours, 30, p. 332; Baty, The Canons, § 5.․

(182) Pedro Lessa, Revista Jurídica, n. II, p. 386; Rodrige Octavio, A Renovação do D. I., p. 27.

(183) Derecho Internacional Público, pag. 66, nota 3. 
Eis porque pode dizer-se que, tambem para o Estado membro de um Estado Federal, a soberania é condição de sua existência como Estado.

Hoje aceita-se que a onipotência do Estado é incompativel com a existência do Direito Internacional.

Compreendem atualmente os govêrnos, livres do antigo e falso princípio da soberania dos Estados, que implica a negação da sociedade internacional e de todo o Direito, que a melhor salvaguarda de sua soberania é a limitação desta (184). Reconhece-se na atualidade a existência e a necessidade de interdependência entre as nações: "Il n'y a plus à l'heure actuelle, dans le domaine économique et social, une seule question de quelque importance qui soit susceptible d'être reglée en dehors du plan international" (BourQuin, Cours, 35, 25) (185).

As nações independentes são interdependentes e é necessário, portanto, para resolver as contradições do mundo moderno, que o nacional se integre no internacional. $\mathbf{E}$ indispensavel limitar a soberania. Podemos, hoje, em Direito Internacional, caracterizar a soberania unicamente como a independência limitada do Estado (186).

AS LIMITAÇõES DA SOBERANIA
Politis (187), em notavel curso feito na Academia de Direito Internacional de Haya (Cours, t. 6.0), sobre o problema das limitações da soberania,

mostra que, todas as vezes que um interesse real tem valor para a comunhão internacional, a liberdade dos Estados é imediatamente limitada proporcionalmente á importância que liga ao valor desse interesse.

Atualmente ninguem mais contesta a inconcetibilidade da soberania ilimitada dos Estados. Soberania e independência, termos equipolentes, em doutrina (SÉfÉriadès, I aApradeile, Politis, etc.) e na prática diplomática, não existem sem limitações na nossa época

(184) Descamps, Cours, 31, 493.

(185) " the Nations have become so interdependent that what happens in one or word countries effects the others" (NoRMaN Davis. For. Aff., vol. 12. n. 2 - Special Supplement).

(186) A. Cavaglieri, Cours, v. 26, p. 322.

(187) N. S. Politis, nasceu em Corfú, na Grecia, em 1872, descendente de uma antiga família de sábios universitários e médicos das ilhas Jônicas. Publicou varios trabalhos de Direito Internacional, e é Vice-Presidente do Curatório da Academia de Direito Internacional de Haya, sendo considerado um dos maiores internacionalistas da atualidade. 
em que a solidariedade dentro e fora das fronteiras é o fato dominante e caracteristico.

A Soberania como poder supremo e incontrastavel que não conhece outra vontade humana superior á sua, considera-se hoje um dogma bolorento e inadmissivel (188).

Si o Estado é soberano, não se pode submeter a regras imperativas, é impossivel a existência entre Estados de um verdadeiro direito, dai a inexistência do Direito Internacional.

Desmoralizada a soberania no conceito tradicional foi tratada em Direito Público como dogma inadmissivel (189).

Reconhece-se hoje que o velho dogma da soberania é incompativel com o Direito e existência de uma comunhão jurídica internacional (190), que é inconsistente, contraditório e sem sentido (KELSEN) que torna impossivel uma vida internacional e leva á anarquia (RALston) (191).

Alguns chegam a propor a eliminação completa da linguagem juridica dessa expressão, e afirmam que não se deve falar mais em soberania.

Salienta PoLitis que, em matéria de liberdade de comunicações e de trânsito, foi bastante limitada a soberania dos Estados. A medida que os meios de transportes oferecem um interesse internacional, são subtraidos á liberdade dos Estados e submetidos a um controle coletivo. $\mathrm{O}$ isolamento comercial é interdicto ao Estado, donde se conclue que a Sociedade internacional não é uma sociedade voluntária, mas sim uma sociedade necessária.

Diz Pourtis que um país não tem o direito de se recusar ao comércio internacional. Ha um mínimo de relações cada vez aumentadas pelo Direito ás quais ele tem o dever, a obrigação jurídica de se prestar. Atualmente não se admite que um Estado modifiquc por suas leis os seus compromissos internacionais, e o próprio Poder Judiciário está limitado pelo princípio da responsabilidade internacional. Modernamente, considera-se obrigatório para os Estados tratar os estrangeiros de acôrdo com os princípios do Direito Internacional. Mesmo atos conformes ao Direito Interno aplicaveis aos nacionais si contrários ao Direito Internacional têm como con-

(188) Acreditamos tanto no mito da soberania, na acepcão clássica tradicional, como na realidade das relíquias que NUNO DE Santa Maria (nome do Santo Condestavel depois de religioso) doon e a que faz referência Frei Joseph Pereira de Sant'Anna, na sua Chronica das Carmelitas. (Lisbôa, MDCCXLV).

(189) Duguit, pag. 438.

(190) David J. Hill, pag. 22; Duguit, pag. 438, 555 e 556.

(191) Le Droit International de la Démocratie, pag. 173. 
sequência a responsabilidade do Estado, e daí, como corolário, a responsabilidade do Estado; em razão dos danos sofridos pelo estrangeiro em operações bélicas, em motins ou guerras civis.

Nem mesmo em relação aos súditos tem o Estado liberdade absoluta de ação. 0 Direito Internacional protege as minorias étnicas.

Mas a maior de todas as limitações a soberania do Estado é o impedimento de fazer a guerra. Nas suas relações não têm os membros da Sociedade das Nações o direito ilimitado de guerra. E entre eles o recurso á fêrça está proibido, ao menos em princípio.

Lembremos ainda o protocolo de Genebra (2 de outubro 1924), e o Pacto de Locarno: atividade constante para pôr a guerra fora da lei.

Temos assim mostrado a necessidade e a evidência das limitações da soberania. Só é possivel organização internacional com a limitação da liberdade de agir de seus membros, usando os Estados de sua liberdade, sob a égide do Direito.

Pode conceber-se perfeitamente o Estado nacional respeitado e independente da mesma forma que os individuos são livres nas sociedades internas. As limitações das liberdades individuais são feitas tendo em vista as vantagens coletivas e portanto os interesses dos próprios indivíduos.

As limitações da liberdade dos Estados têm que ser feitas no interesse da comunhão mundial e portanto no interesse dos próprios Estados.

\section{RECONHECIMENTO}

1 - Lafayette, \& $3 .^{\circ}$.

2 - OpPENheiM, I, \& 71, p. 131.

3 - Verdross, Cours, 30 pag. 325.

4 - Erich, Cours, 13.

5 - Splropoulos, D. I. pag. 130.

6 - Acciol1, pag. 128 .

4...The graning of recog nition is a matter of policy, and not of law" (Opp. I, \& 73).
Reconhecimento é o ato pelo qual fica claro que um Estado antigo está disposto a tratar um outro como membro da Família das Nações (OPPENHEIM).

O reconhecimento pode ser expresso ou tácito.

\section{DUAS DOUTRINAS}

Existem duas doutrinas sobre o reconhecimento:

1) - Basta formar-se um Estado, desmembrando-se de uma pessoa internacional, por exemplo, para tornar-se outra pessoa internacional, isso independentemente de reconhecimento (Hall, Gareiss, Kluber, Carnazza, Amari), ape- 
nas o Estado não poderá entrar em relações com os outros membros da Sociedade internacional que não o reconheceram;

2) - Um Estado torna-se pessoa internacional, única e exclusivamente pelo reconhecimento (OPPENHEIM, I, § 71, pag. 134).

LAFAYETTE é da primeira doutrina (§ 31), argumentando com o caso do reconhecimento tácito, o que ninguem contesta (nota 1 ao $\$ 31$ ).

Como dissemos, o reconhecimento é expresso quando se faz por declaração direta em Tratados ou em atos diplomáticos: tácito quando resulta de atos que virtualmente presupõe a existência da pessoa internacional, como é a celebração do Tratado, a enviatura e recebimento de agentes diplomáticos (192).

Modernamente tem grande importância a distinção entre reconhecimento de fato e de jure (193).

NAO E' OBRIGAT'́-

RIO. PÓDE SER

CONDICIONAL

\section{RECONHECIMEN- TOS PRECIPITA- DOS E TARDIOS}

O reconhecimento não é obrigatório e pode ser dado sob condições. O Congresso de Berlim reconheceu, em 1878, condicionalmente, a Bulgária, o Montenegro, a Sérvia e a Rumânia.

0 momento em que deve ser feito o reconhecimento depende de cada caso especial. A nação que reconhece é a única competente para julgar da oportunidade de fazê-lo (194).

Ha reconhecimentos precipitados e outros tardios. O reconhecimento dos Estados Unidos pela França, em 1778, foi precipitado, mas si fosse feito em 1782, já não seria inoportuno, em vista de terem sido os Estados americanos reconhecidos já pela metrópole.

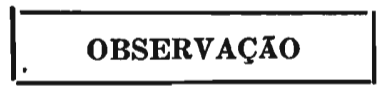

vêrno, de títulos do Estado ou de insurgentes como beligerantes (195).

(192) LafayetTe, $\S 31$; Verdross, Cours 30 , pag. 331.

(193) Verdross, Cours 30, pag. 331; veja-se tambem Baty, The Canons, pag. 203 e segts.

(194) Lafayette, § 31; Phillimore, § 16; Hall, § 26.

(195) WeSTLAKE - I, 50/57. 
Destas, trataremos oportunamente (196). Observaremos, contudo, que a entrada para a Sociedade das Nações deve ser considerada como um reconhecimento coletivo (197).

MUDANÇA NA CONDIÇÃO D AS PEŚ-

SOAS INTERNACIONAIS

1 - Grócio II, Cap. 3., \& 5. a 13.

2-OPPENHEIM, I, $\& 76$, p. 3 - Calvo, I, $\$ 81$ a 100.

\section{MUDANÇAS NO} TERRITÓRIO

A existência das pessoas internacionais está sujeita a mudanças importantes e indiferentes.

Ha mudança nos cidadãos, no govêrno e no território, indiferentes e não afetando a existência da pessôa internàcional.

As mudanças no território, pela continuidade do Estado, não afetam a sua personalidade internacional. A Prússia, pela Paz de Tilsit de 1807, perdeu a terça parte do seu território, e o reino da Saxônia, pelo Tratado de Vienna, perde a metade de seu território. Perde a Austria, em 1859, a Lombardia, e em 1866, Veneza.

Modernamente, a expansão da Sérvia, transformada no Estado Sérvio-Croata-Sloveno, depois da Grande Guerra, é um outro exemplo do que acabamos de afirmar.

Estas mudanças, conservada a continuidade do Estado, não afetam a sua personalidade internacional. A nação mantém sempre a identidade de sua pessoa enquanto subsiste como associação política. A perda de secções de território nada significam, porque as nações conservam a identidade juridica de suas pessoas, uma vez que as partes que lhes ficam sejam suficientes para a manutenção de sua existência. E o que ensinam Phillimore, I, § 126; Martens, I, 68; MOORE, $\S 76$, etc..

MUDANÇAS NA POPULAÇÃO

Renova-se a população sem que a personalidade internacional seja afetada. A accessão de novos elementos etnográficos, a vinda de indivíduos e familias de outras origens e raças, não destroem a identidade da nação.

(196) OPPENheim, I, § 75, p. 139.

(197) Verdross, Cours 30, pag. 331. 
A Prússia, por exemplo, no tempo do grande Eleitor, recebe os protestantes franceses. Outro exemplo é Gênova, no século XVI. Este ensinamento vem de Grócıo, § 3..$^{\circ}$ n. 3.

MUDANÇAS NO GOVERNO

As mudanças no govêrno não afetam tambem a personalidade das nações. Ensina LafayetTe ( $(30$ ) que não influem na identidade do Estado as transformações, radicais que sejam, de sua constituição interna, porque não é a Constituição que dá o SER á nação; ao contrário, a Constituição é que é um produto da nação. Daí tira o grande jurisconsulto pátrio os seguintes princípios:

1) - Que subsiste sempre para a nação a obrigação de cumprir os tratados, convenções e ajustes por ela legalmente celebrados em qualquer tempo ou época, enquanto não deixarem de vigorar por alguma razão de Direito;

2) - Que é sempre responsavel pelos prejuizos, perdas e danos que no procedimento injusto dos seus govêrnos, havido em qualquer tempo, resultarem em detrimento de outros estados ou de súditos dele;

3) - Que ligam e obrigam a nação em todo o tempo, os atos de cessão de bens e Direitos que em nome dela houverem sido realizados, como alienação de bens do domínio público;

4) - Que se reputam legitimamente entrados para o seu patrimônio todos os bens e direitos que a qualquer tempo tenham sido legalmente adquiridos pelos que a hajam governado.

Acrescenta LAFAYETTE que a doutrina exposta vigora em toda a sua plenitude, ainda quando os atos que determinam a responsabilidade da nação ou serve de fundamento á aquisição de Direito, tenham sido praticados por govêrno de fato.

De idêntica opinião, Piedelievee, n. 137, bis; Rivier II, § 3, n. 13, 1 e 2. E realmente o Estado sempre continua obrigado pelos atos de um usurpador. Luiz XVIII e Luiz Phelippe indenizaram os prejuizos dados por Napoleão I, e o rei das duas Sicilias pagou aos americanos os de Murat.

A República Brasileira respeitou todos os compromissos do Império. Estas mudanças podem ser importantes para o Estado, mas não interessam muito o Direito Internacional e não afetam a sua personalidade internacional. De tamanha importância pode ser uma 
destas mudanças, que, como vimos, o não reconhecimento de um govêrno impede as relações internacionais.

MUDANÇAS QUE

AFETAM A PER-

SONALIDADE

INTERNACIONAL

Ha mudanças que afetam a personalidade internacional do Estado. Quando dois Estados se unem formando uma união real, os dois Estados têm a sua personalidade internacional afetada. Ainda, muitas restrições podem ser postas á indepedência dos Estados. Evidentemente, numerosas restrições podem ser impostas aos Estados sem afetarem propriamente a sua independência.

Contudo, ha restrições que envolvem perda parcial da independência, por exemplo, quando o Estado soberano se torna semisoberano.

\section{ESTADO NEUTRA- \\ LIZADO PERMA- NENTEMENTE}

O Estado neutralizado permanentemente torna-se pessoa internacional de uma classe especial, tendo a sua personalidade internacional alterada, conquanto mantenha-se Estado independente.

A concepção do Estado neutralizado é a seguinte: trata-se de um Estado cuja independência e integridade ficam garantidas por uma convenção internacional de potências, sob a condição de que este Estado se obriga a nunca tomar armas contra outro Estado, exceto defendendo-se contra um ataque, a nunca contrair obrigações que possam trazer como consequência a guerra. Trata-se de um Estado plenamente soberano.

Diz LAFAYETTE ( $(39)$ que a obrigação de observar e manter neutralidade absoluta não lhe destróe a personalidade internacional, mas lhe restringe a liberdade, inibindo de contrair compromissos com quaisquer outros ou de lhes prestar, em caso de guerra, auxilios c socorros sob qualquer forma.

Parece-me que o Estado neutralizado, salvo caso de solução de questões de fronteira, não pode nem ceder nem adquirir porções de território sem o consentimento das potências que garantem a sua neutralidade. Esta nossa afirmação contudo é muito discutida (198).

o Estado neutralizado póde para defender-se possuir um exército e uma armada e construir fortalezas, desde que o seu fim seja unicamente preparar a própria defesa.

(198) Descamps, La neutralité de la Belgique, etc. 
o caso do Luxemburgo, neutralizado sob a condição de não possuir força armada, deve ser considerado como uma exceção.

Os Estados neutralizados podem ter uma importância internacional extraordinária. Apontaremos a Suissa.

A Suissa, como salienta Nitri (Dém. II, p. 328), oferece em ponto pequeno a imagem do que poderia ser dentro de alguns séculos uma Europa civilizada: reunião livre e espontânea sob a mesma lei de homens, de raças, de línguas e de religiões diferentes.

Os Estados neutralizados são na Familia das Nações uma exceção. No século XIX surgiram, na comunhão internacional, os Estados neutros como Cracóvia, a Suissa, a Bélgica e o Luxemburgo.

Cracóvia (199) foi neutralizada permanentemente pelo Congresso de Vienna, em 1815, e annexada pela Austria, em 1846. A Bélgica foi neutralizada pelo Tratado de Londres (15 de novembro de 1831, art. 7.'), e a sua neutralidade foi garantida no art. 25 pela Inglaterra, Austria, França, Prússia e Rússia, e a garantia renovada pelo Tratado de 19 de abril de 1839, art. 2.0, celebrado em Londres.

Violada a neutralidade belga pela Alemanha, em 1914, terminada a Grande Guerra, a Bélgica deixou de ser um país neutro (Tratado de Paz com a Alemanha, art. 31, e com a Austria, art. 83).

Sobre a Bélgica ver:

1) Sherman, American Journal (1918);

2) OPPENheim, § 99; e,

3) Descamps (A neutralidade da Bélgica, 1902).

Quanto ao Luxemburgo, ainda alguns o sustentam neutralizado (200) o que não parece razoavel (201), pois solicitou sua entrada para a Sociedade das Nações em fevereiro de 1920, permanecendo neutralizado, e só foi admitido em novembro, sem reserva alguma (202).

S U I S S A
A Suissa é atualmente o único Estado neutralizado permanentemente (203).

(199) Nys, I, pag. 414-417.

(200) BorSI, Riv. Dir. Int. 1925, 3-7; WEREN, Rev. Ger. Dr. In. Pub., 1924, 169.

(201) OPPENHEIM, I, \& 97-100.

(202) V. T. Verdross, Cours, 30, 299 e 300.

(203) Oppenheim, § 97 e 98. 


\section{L A S S ES D E ESTADO \\ I - LAFAYETTE, I, p. 61, \& 33. \\ 2 - OPPENHEIM, I, p. $152,85$. \\ 3 - Skrgio Loreto Frlho, Clas- sificação dos Estados, (Re- cife, 1917). \\ 4 - Verdross, Cours 30, p. 322. \\ 5 - Accioli, n. 131 e segts.}

\section{UNIAOO PESSOAL}

Acc10L1, n. 136.
Os Estados são simples ou compostos. Os Estados compostos são a União Real e o Estado Federal. A união pessoal e a confederação não são pessoas internacionais.

duo para monarca. Exemplo: GRAN BRETANHA e HANOVER (1714-1837), ISLÂNDIA (Regelsperg Rev. SC. Polit. 15 de junho de 1920), LITUÂNIA e POLONIA (de 1386 a 1569).

POSIÇAOO INTERNACIONAL

Trata-se no caso de pessoas internacionais separadas (204). Podem mesmo teoricamente fazer-se a guerra. São muitas vezes representadas pelos mesmos agentes diplomáticos, mas estes representam, não a união pessoal, mas sim cada um dos Estados separadamente.

UNIÃO REAL

Accrolr n. ${ }^{\circ} 139$ e segts.
Denomina-se união real a reunião de dois ou mais Estados soberanos, por tratado internacional, reconhecido pelos outros Estados, para formar exteriormente uma única pessoa internacional (205). As leis e instituições políticas do Estado mantem-se distintas. No interior, em resumo, vários Estados soberanos; no exterior, um único: a união real. Exemplo: SUÉCIA e NORUEGA (206). Tornaram-se união real em 1814.

Dissolvida pacificamente em 26 de outubro de 1905 (Tratado de Stockolmo, conclusão das reuniões de Karlstad).

AUSTRIA-HUNGRIA - Tornou-se união real em 1723. Terminou, depois de várias vicissitudes, com a Grande Guerra.

(204) LAFayette, § 34.

(205) PufendoRfF, 7, 5, § 17.

(206) Essa é a opinião de Opp., I, § 87, e LAFayeTte, § 34, mas não é a de outros ilustres internacionalistas como PHILLImoRE, I, § 74, e Twiss, I, § 40. Aquele dizia tratar-se de uma união pessoal, e este de uma união federal. 
CONFEDERAÇÃO

1 - LAFAYETte, I, \& 35.

2 - Accrol, ns. 142 - segts.
"Confederated States (Staatenbund) are a number of full sovereign states linked together for the maintenance of their external and internal independence by a recognised international treaty into a union with orgams of its own, which are vested with a certain power over the member states, but not over the citizens of these states" (OPPENHEIM, Int. Law, I, pag. 156). Ou em português: "CONFEDERAÇÃO é a reunião de Estados soberanos por tratado internacional para manter sua independência interna e externa, formando uma união, com órgãos próprios, com poderes sobre os Estados membros, mas não sobre os cidadãos desses Estados".

\section{POSIÇÃO INTER- NACIONAL}

Não é uma pessoa internacional, como vimos. A Confederação é, na réalidade, uma mera aliança (LAFAYETte, § 35).

O principal e ás vezes único órgão da união ẻ uma Dieta, onde os Estados membros são representados por agentes diplomáticos. A Dieta está investida de um poder internacional que não afeta a plena soberania dos Estados membros. O corpo confederado pode guerrear para obrigar um dos seus membros a obedecer ás deliberações da Dieta conformes com o tratado de Confederação: a guerra entre os Estados membros é proibida em outra hipótese (Opp., § 88). E' bom advertir que se podem ligar em confederação os Estados monárquicos, os republicanos e os monárquicos com os republicanos. É a lição de Lafayette ( $\$ 35$ ), contrária á de Montesquieu (L. 9, cap. 2).

Exemplo: Estados Unidos, de 1778 e 1787. Alemanha, 1865 a 1876. Suissa, 1791-1798 e 1815-1848. Maior República da America Central (Honduras, Nicarágua e Salvador) de 1895-1898.

\section{ESTADO FEDERAL \\ LAFATETTE, \& 36.}

E' a união perpétua de vários Estados soberanos, com órgãos próprios e investidos de poder não só sobre os. Estados membros como sobre os individuos desses Estados.

Essa doutrina é a ideada e exposta pelo Federalista e aceita por Kent e Story, as maiores autoridades de Direito Constitucional na América do Norte. A soberania está dividida entre a união e os 
Estados, sendo cada um soberano na sua esfera de ação (207). Essa distinção entre Federação e Confederação pode ser estudada com proveito em Lafayette, I, §§ 35 e 36, Oppenheim, I, 89 , e Merrian, "History of sovereignty since Rousseau".

Observamos que ha duas espécies de Federação: as do tipo germânico e as do tipo americano.

A Federação do tipo germânico ou império federal, observa Diena, é um tipo anômalo. Nas Federações de tipo americano, como a nossa, o Estado federal absorve a soberania externa dos Estados membros e estes não aparecem portanto nas relações internacionais. Continuam, porém, internamente soberanos (Merrian, Hist. of Sov., pag. 163) na sua esfera de ação.

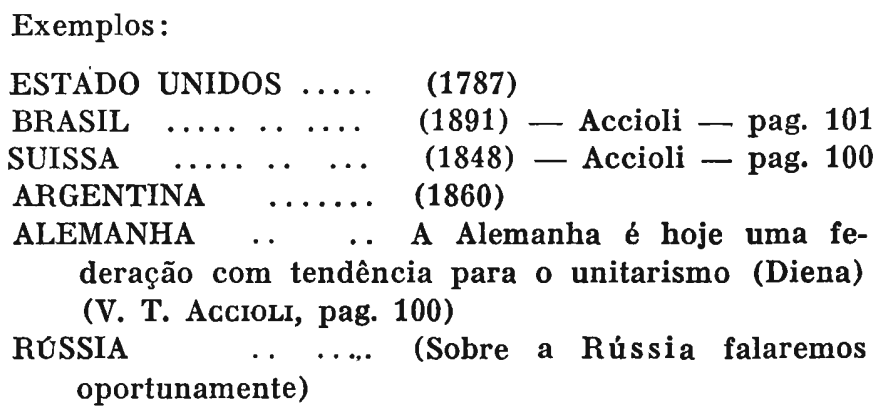

E' de notar que algumas das Repúblicas que fazem parte da União das Repúblicas Soviéticas Socialistas (URSS) estão organizadas, por sua vez, sob a forma Federativa. Alguns dos dominios britânicos acham-se organizados politicamente tambem sob a forma de Federações.

ESTADOS VASSALOS

Acciour, p. 105.
Os Estados feudatários, ou vassalos, são aqueles que estão para com os outros em relações de dependência análogas ás que existiam entre o vassalo e o suzerano (208). Sobre eles não se pode dar uma regra fixa, pois tudo depende de cada caso especial. Estão, contudo, sob uma espécie de tutela internacional (209).

(207) MERrian - History of Sov. p. 163.

(208) LafayetTe, § 38; OPPENheim, § 90.

(209) OPPENHEIM, $\S 90$ e 91. 


\section{ESTADOS PROTEGIDOS \\ Opp. I, $\$ 92$.}

Estado protegido é o que, por não ter força suficiente para sustentar a sua independência, defender o seu território, ou ainda resguardar-se da opressão e injúrias, coloca-se sob a proteção

de um Estado mais poderoso mediante condições definidas (210).

Sobre os protetorados não se pode dar uma regra geral, porque o protetorado é susceptivel de graus (211). Em regra o Estado mais fraco entrega ao mais poderoso a direção de seus negócios exteriores mais importantes, tornando-se, dest'arte, um estado semi-soberano E uma espécie de tutela internacional (a kind of international guardianship), podendo dizer-se que o protetorado é uma instituição que carece de precisão jurídica, eis que sua real significação depende muito do caso especial (212). Geralmente o Estado protegido não se funde no Estado protetor, e porisso mesmo o cidadão do Estado protegido nem sempre o é do protetor (213), e os tratados celebrados pelo protetor com terceiros nem sempre obrigam o protegido, podendo este permanecer neutro em guerra feita por aquele (214). Em regra o Estado protegido mantem-se independente e conserva a sua personalidade internacional. Ás vezes, o protetorado é imposto como o da Inglaterra ao Egito.

\section{Exemplos}

1) ANDORRA (215) que participa tambem do caracter de Estado vassalo por pagar tributo aos protetores (216);

2) SÃO MARINO, que alguns proclamam plenamente soberano;

3) ISLÂNDIA, cuja posição é duvidosa;

4) DANTZIG, sob a proteção da Sociedade das Nações (217);

5) MONACO (218).

(210) LAFAYETTE, § 37.

(211) Grócio, l. I, cap. 3, § 21, n. 10; Phillimore, I, § 76.

(212) OPPENHEIM, §§ 92/93.

(213) BynK Q. J. P. I., cap. 9; LafayetTe, Hall.

(214) HaLL, § 4..$^{\circ}$ Opp., § 93.

(215) Foreign Affairs, I, 934, vol. 12, n. 2.

(216) Accroli, pag. 114.

(217) Accioli, pag. 118; OPPENHEIM, pag. 189.

(218) Fauchille, I, pag. 270; Accioli, pag. 114. 
ESTADOS CLIENTES

em relação aos Estados Unidos. São os denominados Estados clientes por outros. Estão nesta condição de dependência CUBA, PANAMA', a REPÚBLICA DOMINICANA, HAITI e NICARÁGUA.

MANDATOS INTERNACIONAIS

1 - Jean Devaux, p. 145. 2 - Accioli, p. 122.

POSIÇÃO INTER-

NACIONAL DE OUTROS ESTADOS
Pelo artigo 22 do Pacto da Liga das Nações, ficam criados três tipos ou classes de mandatos internacionais, que foram confiados a certos Estados pela Liga sob condições determinadas...

Já nos referimos aos Estados neutros, isto é, áqueles cuja independência e integridade ficam para sempre garantidas pelas potências, sob condição de nunca pegar em armas contra outros Es-

tados, ou celebrarem tratados dos quais possa resultar a guerra (219). E poderiamos completar o nosso estudo tratando da posição internacional da RúSSIA SOVIÉTICA (220), o que só faremos oportunamente.

Do IMPÉRIO BRITANICO e da SANTA SÉ, trataremos mais tarde. Vejamos agora a posição dos Estados não cristãos.

ESTADOS NÃO CRISTAOS

1 - Opp. I, 8 102.

2 - NYs, I, p. 126
Exceto a TURQUIA e o JAPÃO, plenamente soberanos e tratados em pé de perfeita igualdade pelos outros Estados membros da Família das Nações, os outros Estados não cristãos ocupam uma posição duvidosa.

A posição internacional da CHINA, do SIÃO, da PERSIA e da ABISSINIA, não é perfeitamente clara. Devem, comtudo, os Estados tratar com essas nações de posição internacional duvidosa e de civilização muito diferente da nossa, de acôrdo com os princípios da moral cristã.

(219) Oppenherm, vol. I, pag, 181.

(220) Accioli, pag. 104. 
O SIÃO, a CHINA e a PÉRSIA são membros da Liga das Nações e procuram, por todas as formas, assimilar os principios da moral cristã e da nossa civilização (221).

Diz muito bem LoRd Phillimore que um povo bárbaro sem absolutamente nenhuma organização não está protegido senão pelos princípios da moral e da religião (222). Os mesmos princípios devem ser aplicados quando se trata de castigá-los (223).

AXEL MöLlER, o insigne internacionalista dinamarquês, ensina que os Estados que se acham fora da Familia das Nações não devem ser tratados arbitrariamente. Em relação a esses Estados, os Estados mais civilizados devem observar os ditames da humanidade, da moralidade e da religião, o mais que seja possivel, conquanto não sejam estrictamente obrigados a fazê-lo.

\begin{tabular}{|c|}
\hline NASCIMENTO DAS \\
NAÇбES \\
1 - Vernnoss, Cours 30, p. 324. \\
2 - Accio1, pag. 126.
\end{tabular}

Exemplos: Divisão do Império de Carlos Magno; divisão do reino dos Paises Baixos, em Hiolanda e Bélgica. Uruguai separandose, em 1828, do Brasil.

2) - Reunião de duas ou mais nações em uma só (225).

Exemplo: Itália, resultado da união dos Estados da Península.

3) - Por separação.

Exemplo: Cisplatina.

4) - Independência de colônias (226).

EXEMPLo: Repúblicas americanas.

5) - Por ato diplomático.

Exemplo: Rumânia (Tratado de Berlim, 1878, art. 43).

(221) Axel Möluer, pag. 5.

(222) Axel Möller, pag. 6, afirma que um Estado completamente incivilizado está inteiramente fora da Família das Nações e exemplifica com o Nepal, o Buthan e alguns pequenos Estados da Arábia. Estes tornam-se cada vez mais raros.

(223) Curso de Direito da Academia Internacional de Haya.

(224) Grócio, 2, 9, § 10; Phillimone, I, § 137.

(225) Grócio, t. 2, cap. 9, § 9; Puffendorf, 8, 12, 6.

(226) Grócio, 2, 9, § 10; Pomeroy, § 50. 


\section{EXTINÇAO DAS PESSOAS INTER- NACIONAIS \\ OPPENHEIM, I, \& 79.}

Os Estados deixam de ser pessôas internacionais, quando deixam de existir. Teoricamente é possivel a extinção de um Estado, pelo desaparecimento total de seu território (227) ou emigração de toda a sua população (228) ou pela anarquia permanente. Esses dois casos rara vez acontecem, e deles não ha exemplo nos tempos modernos (229).

Os casos mais vulgares de extinção das pessoas internacionais são:

1) INCORPORAÇÃO VOLUNTARIA A OUTROS ESTADOS.

Exemplo: Incorporação do Texas aos Estados Unidos (1843); o Ducado de KURLÂNDIA, em 1795, incorpora-se á Rússia; os Principados de HOHENZOLLERN-HELCHINGEM e HOHENZOLLERN SIGMARINGEN (1849) á PRUSSIA; o Estado Livre do Congo, em 1908, à BÉLGICA; e a KORțA, em 1910, ao JAPÃO.

2) UNIÃO DE VÁRIOS ESTADOS EM UM UNICO: Itália.

3) DIVISÃO VOLUNTÁRIA DE UM ESTADO EM VÁRIOS : Maior República da America Central, Rússia, etc.

4) INCORPORAÇÃO FORÇADA DE UM ESTADO A OUTRO: absorpção da Polônia pela Rússia, Austria e Prússia; Estado Livre de Orange e República Sul Africana a Inglaterra (1901).

SUCESSAO DAS PESSOAS INTERNACIONAIS

1 - Lafayette, T. \& 43

2 - Oppenheim, I, $\S 80$.

3 - KeITH - Theory of State Succession (1907)

4 - Grócio, II, C. 9 e 10.

5 - Puffendorf, VIII, C. 12.

6 - Moore, I, \& 92/99.

7 - HeFrstes, \& 25

8 - Focherini - La Successioni degli Stati.

9 - Cavaglieri - La Dot'rina della Successione de I:aloStato (1910).
Não ha acôrdo entre os escritores sobre a sucessão das pessoas internacionais. A doutrina mais comum, contudo, é a que vou expor em seguida.

Dá-se uma sucessão de pessoas internacionais, quando uma, ou mais pessoas internacionais, tomam o lugar de outra pessoa em consequência de qualquer mudança na condição desta: "A succession of International Persons occurs when one or more international persons take the place of another international person, in consequense of cer-

tains changes in the latter's condition" (OPPENHeIM, I, $\S 80$ ).

(227) Grócro, t. 2, cap. 9 § 4. - "Ad priorem modum refer populos mari abreptos, ut Atlantiae populos, teste Platone et aliosquos Tertulianos meminit; item eos quos terrae motus haurit penitus" Ex antiquo Latio LIII populos sine vestigiis inter isse, ait Plinio. - Pufendorf, 8, $12 \S 8$.

(228) Grócio, 1. 2, cap. 9 \& 5.

(229) LAFAYETTE, § 42. 
A sucessão pode ser:

1) Universal - quando uma pessoa internacional é absorvida por outra, por incorporação voluntária ou forçada, e tambem quando um Estado se fracciona em outros que se tornam pessoas internacionais, ou são absorvidos, anexados por outros Estados.

2) Parcial:
a) Quando uma parte do território se torna indepen- dente;
b) Quando uma pessoa internacional adquire uma parte do território de outra por cessão;
c) Quando um Estado soberano entra para uma fe- deração;
d) Quando uma pessoa internacional entra para união reaī, ou vice-versa.

Ninguem sustentará hoje que, em Direito Internacional, haja uma sucessão de todos os Direitos e obrigações. Na matéria, tudo depende, como ensina Oppenherm, que sigo nesta lição, do caso especial.

Alguns autores, contudo, dizem que nunca ha sucessão de pessoas internacionais (CAvaglieri, Gareiss, etc.).

Ensinam eles que, com o desaparecimento da pessoa internacional, desaparecem tambem todos os seus direitos e obrigações. Si não existe uma sucessão universal, é, contudo, absurdo negar que não haja sucessão de pessoas internacionais. Basta observar o que se passa na realidade (Ver LAFAYETTE, I, $\S 43$ e nota 3 ).

\section{A S O S}

Vejamos os casos de sucessão:

1) - ABSORCZAO - Quando um Estado é absorvido por outro, extinguese como pessoa. Direitos e obrigações decorrentes do caracter de pessoa internacional ou tratado puramente políticos, extinguem-se. Assim os tratados de aliança, neutralidade e arbitramento extinguem-se.

$\mathrm{E}$ os tratados comerciais?

Ha discussão. Acho que, conquanto não sejam tratados puramente políticos, têm traços proeminentes políticos, devendo extinguir-se todo tratado comercial com a extinção das pessoas internacionais.

Dá-se tambem uma sucessão quanto aos direitos e obrigações localmente conexas com a terra, os rios, as estradas, etc. 
Os tratados de limites, reparação de estradas, navegações fluviais, ficam válidos e ha sucessão de acôrdo com o princípio res transit cum suo onere.

Ha tambem sucessão da propriedade fiscal e fundos públicos que entram para o patrimônio do novo Estado (Dec. Alta Corte J. S. A. no U. S. V. Prioleau, V. Scott, Cases on Int. Law, pag. 85).

Por uma regra, baseada em costume, ha sucessão das dividas (MOORE Appleton).

O credor privado não adquire direitos contra o novo Estado.

Alguns (Hubfro, HéfFter, etc.) acham que o Estado sucessor deve ficar com as dívidas, mesmo quando o patrimônio é inferior a elas. Mas esta opinião não é sancionada pela prática.

Um Estado que subjuga outro tem que ficar com as dividas de guerra (OPPENHeim contra Westlake). No caso de Federação, tudo depende de circunstâncias especiais. Ha ainda a considerar si a federação é de tipo americano ou germânico.

Sobre concessões a individuos e companhias, tudo é falivel (Moore, Field, Westlake).

2) - DESMEMBRAMENTO - Quando um Estado se desmembra, e forma várias pessoas internacionais, ou é anexado por outros, extingue-se, e aplicam-se-lhe as mesmas regras da absorção.

Quando o território do Estado extinto é absorvido por vários Estados, dá-se a sucessão dos Direitos localmente conexos com a parte dos territórios absorvidos pelos respetivos Estados, da propriedade fiscal e fundos do Estado e uma divisão proporcional das dividas.

Quando se dissolve uma União Real, como a Suécia e Noruega em 1905, ha sucessão e todos os Tratados obrigam os antigos membros, exceto os feitos pela União para um único membro.

3) - SEPARACGÃO E CESSÃO - Ha sucessão dos direitos localmente conexos com o território, da propriedade fiscal e dos fundos públicos.

Parece que uma parte das dívidas deve ficar a cargo do sucessor, hão havendo, contudo, nada de fixo a respeito.

O Tratado de Berlim, de 1878, estipulou, nos artigos 9, 33 e 42, que a Bulgária, o Montenegro e a Sérvia ficariam com uma parte da divida turca.

De modo contrário procedeu a América do Norte en 1898, quanto á divida cubana (230).

(230) Moone, II, § 97, pags. 355 e 385 e vol. I, § 97. 
Contudo, Hubero sustenta que ha uma regra de Direito Internacional que obriga no caso de separação ou cessão a ficar o sucessor com uma parte da divida do predecessor. Como vimos, esta opinião é contestada por OPPENHEIM e outros.

\section{PRINCPPIO DAS NA- CIONALIDADES \\ 1 - Lafayetts, \& 25. \\ 2 - Jorannet - Le Principe des Nationalités - (1918)}

Vejamos em primeiro lugar o que seja este principio das nacionalidades. Forgnet define-o como sendo o príncipio em virtude do qual os Estados devem corresponder ás nacionalidades. Para os seus defensores a coexistência

das nacionalidades constitue a base do Direito Internacional.

Este princípio foi formulado por Mancinı na celebre lição de 22 de janeiro de 1851 (231). Mancini ensinou que a idéia de nacionalidade deduzida do Direito Internacional, para ele uma espécie de Direito Universal, é elementar, e a idéia de Estado é derivada.

MANCINI, levado pelo seu patriotismo, formulou o princípio das nacionalidades em épocas anormais de fermentação e de paixões, e levado pelo seu patriotismo foi longe demais e, em vez de retratar um principio, caricaturou-o.

Os italianos quiseram provar que os esforços de Itália para libertar-se e unir-se eram legitimos, e apelaram para o princípio das nacionalidades, formulado por MaNciNI.

Mas, parece-me, com V. Bulmering, que para unificar-se a Itália não era necessário basear-se o Direito Internacional no princípio das nacionalidades.

Antes de Mancini já a idéia de nacionalidade surgia, e Madame DE STAËL dizia que cada Estado deve compreender um povo com uma língua e costumes semelhantes (232).

Após 1815, como vimos, foi triunfando esse principio, principalmente depois que Napoleão III lhe deu o seu apôio.

Predominou completamente depois de 1877, e sob a sua influência desmembrou-se o Império Otomano, e unificaram-se a Itália e a Alemanha. Durante o século XIX, segundo ensina Martess, o princípio das nacionalidades é glorificado como o mais razoavel fundamento para regular todas as controvérsias possiveis entre os Estados, e para restabelecer uma ordem que garanta a cada povo um desenvolvimento pacifico, em síntese, como uma espécie de panacéia contra todas as veleidades de desacôrdos internacionais.

(231) Della Nazionalitá come fondamento del diritto delle genti, Turim, 1851.

232) Origem da expressão: NrTtr, Dém., I, p. 339. 
ATAQUES AO PRINCÉPIO
Os europeus atacam muitas vezes o princípio das nacionalidades, e tambem o Direito dos povos de se governarem a si mesmos. Mas ha no caso muito in-

teresse e boa dose de má fé. 0 princípio das nacionalidades não é a base do Direito Internacional, nem mesmo pode ser considerado um princípio juridico, mas sim político.

Mas a sua importância é enorme e grande a sua influência na história do Direito das Gentes e na marcha da civilização.

\section{COMO DEVE SER} COMPREENDIDA
A idéia de nação é complexa, antes psicológica que jurídica. Uma nação é uma alma, uma família espiritual, resultante, no passado, de lembranças, de sa-

crifícios, de glórias, ás vezes de dores e recordações comuns; no presente, do desejo de continuar vivendo juntamente.

O que constitue uma nação não é o fato de falar certo número de pessoas a mesma língua, ou pertencer ao mesmo grupo etnográfico; é ter feito juntamente grandes coisas no passado e querer ainda fazê-las no futuro. A nação é um princípio espiritual resultando de complicações profundas da história, conforme ensina RENAN (Discours et Conférences).

Como estamos longe dos que falam em panslavismo, ou pangermanismo, como consequência do princípio. $E^{\prime}$ do ponto de vista elevado de Renan que devemos estudar a matéria e conceber o princípio das nacionalidades (233).

\section{EXEMPLO SUISSO}

A Suissa, amálgama de povos diferentes, é o exemplo mais acabado de uma nação tal como a concebemos, e talvez a mais legitimamente constituida da Europa, como afirmava 0 mesmo RENAN.

NipPold diz que muitos quiseram contestar á Suissa a qualidade de nação, porque esse país se compõe de povos diferentes pela raça e pela lingua, e, contudo, observa o grande internacionalista, o suisso tem a convicção de que constitue uma nação como se a Suissa fosse povoada por habitantes falando uma única língua.

(223) NitTi, Dém., II, pag. 322-3. 
A SUISSA E A SOCIEDADE DAS NAÇÕES

E' de notar, como observa Nippold, que a Suissa com as três raças e as suas três culturas, forma uma sociedade de nações em miniatura. Prova que, apesar dessas diferenças, pode-se viver em

boa harmonia, que um Direito Internacional mais elevado do que o que existe atualmente, não é uma impossibilidade, bem como uma sociedade das nações na sua verdadeira acepção. Oxalá se entendesse sempre assim a idéia de nacionalidade. Bem compreendida, significa a paz, mal compreendida, o ódio, a paixão, a guerra.

\section{A GRANDE GUERRA E O PROBLFMA DAS NACIONALIDADES}

Durante a conflagração européia, mais de uma vez foi proclamado o direito das nacionalidades pelos aliadós.

"Il n'y a pas de paix possible tant que ne seront pas assurées la réparation des droits et libertés violés, la reconnaissance du principe des nationalités et la libre existence des petits États" (234). Assim, de acôrdo com essa política, formaram-se a nação Polaca e a TchecoSlováquia.

O principio da proteção ás minorias é mais moderno e significa a garantia dos interesses nacionais, linguísticos e religiosos das minorias étnicas dentro de fronteiras determinadas (235).

Não nos devemos esquecer ainda de outro principio, caracteristicamente político, o da porta aberta (policy of the open door), proclamado em varios tratados garantidores da liberdade comercial e do direito de intercâmbio internacional (Tratado de Washington de 6 de fevereiro de 1922 (China), artigos 22 e 23 do Pacto da Liga das Nações e Conv. de Barcelona, 20 de ábril de 1921).

O Govêrno Provisório russo, em declaração de 9 de abril e 18 de maio de 1917, reconheceu tambem o Direito dos Povos de disporem de seus próprios destinos.

W I L S O N
Mas o maior paladino do Direito dos povos foi o grande idealista WiLson. A sua doutrina iluminou o mundo durante algum tempo, foi o verbo da paz, a palavra da Justiça. A doutrina wilsoniana foi aceita pelos alemães e austriacos (notas de

(234) Nota de 30 de dezembro de 1916.

(235) Duparc - La protection des minorités de race, de langue et de religion (1922). Mandelstan, Cours, 1929. 
12 e 27 de outubro de 1917) e pelos aliados (nota de Lansing a Sulzer, 6 de novembro de 1918). Wilson limitava a soberania do Estado pelo Direito Superior da Humanidade.

PALAVRAS DE WILSON

A América combate " . pour la libération des peuples, quels qu'ils soient, des aggresions de la force autocratique" (Dec. 9-1-1917, á Rússia).

Em Mont-Vernon, no discurso de 4 de julho de 1918, preconiza a "destruction de tout pouvoir arbitraire en quelque lieu que ce soit, qui puisse isolément, secrétement et de par sa seule volonté troubler la paix du monde".

"Todo povo tem o direito de escolher a soberania sob a qual é chamado a viver" (27 de maio de 1916). Esta última declaração foi modificada posteriormente.

O DISCURSO DE 22

DE JANEIRO DE 1917

"Uma salvaguarda inviolavel da existência do culto e do desenvolvimento social e industrial deveria ser garantida a todos os povos que viveram até aqui sob o domínio de govêrnos ligados a uma fé e a fins politicos diferentes dos seus". Aí fala WiLson não em independência plena, mas sim em um minimo de direitos (uma autonomia).

Em geral, a doutrina wilsoniana opõe aos direitos das nações os do Estado, e dilimita estes dois direitos pelo fim comum da humanidade.

Mas como?

\section{MENSAGEM PRESI- \\ DENCIAL DE 11 DE FEVEREIRO DE 1918}

De acôrdo com a mensagem de 11 de fevereiro de 1918, como muito bem diz Mandelstan, o ilustre internacionalista russo, no seu curso na Academia de Direito Internacional de Haya (1923), monumental trabalho que muito me tem servido na exposição da matéria: “Cada parte do regulamento final deve ser baseada sobre a Justiça do caso particularmente considerado, e arranjos mais adaptaveis á consecução de uma paz permanente" (ponto 1).

“Todas as aspiraçǒes nacionais bem definidas deverão receber a mais completa satisfação possivel sem introduzir ou perpetuar 
antigos elementos de desordem ou de antagonismo, susceptiveis, com o tempo, de romper a paz da Europa, e portanto do mundo" (ponto $\left.4 . .^{\circ}\right)$.

\section{CONCLUSÃO DA DOUTRINA WILSONIANA}

"Em suma, a doutrina wilsoniana reconhece em principio a necessidade de satisfazer as aspirações nacionais; mas reserva o exame da "Justiça essencial de cada caso particular" e limita

essas aspirações pelos interesses superiores da paz mundial.

Segundo a doutrina wilsoniana, em caso de conflito entre o Estado e as nações que fazem parte dele, a solução não será uniforme: ora será favoravel ao Estado, ora á nação, segundo os interesses superiores da sociedade humana".

SAO AS NAÇÕES SUJEITOS DE DIREITO INTERNACIONAL?

Diena discute elegantemente a tese de saber-se si as nações podem ser pessoas de Direito Internacional. Diz ele que para excluir a idéia de que as nações possam ser sujeitos do Direito Internacional, basta observar que, enquanto os Estados possuem uma personalidade jurídica, ou antes, são as pessoas jurídicas por excelência, o contrário acontece com as nações enquanto não adquirem a forma de Estado. Seria talvez vantajoso que as bases para a constituição dos Estados fossem as nações, mas não é esta a missâo do Direito Internacional.

Demais, observa Diena, é dificil distinguir as nacionalidades. Como caracterizar uma nação de forma a diferençá-la perfeitamente de outras? 0 elemento étnico não é suficiente, porque os povos são o resultado de mesclas e cruzamentos de raças diversas. As fronteiras naturais e a lingua não caracterizam perfeitamente a nacionalidade. Devemos concluir por numerosas razões que, si é desejavel que os diversos povos se organizem politicamente de acôrdo com os seus caracteres nacionais, devemos, contudo, considerar como sujeitos de Direito Internacional, não as nações, mas os Estados que fazem parte da comunhão jurídica internacional, estejam ou não constituidos sob uma base nacional.

PROTEÇ̃̃O ÁS NACIONALIDADES
Si as nações não são as pessoas internacionais, contudo as minorias étnicas são protegidas pelo Direito Internacional. Os tratados que poseram fim á 
Grande Guerra, obrigaram os Estados a conceder a todos os habitantes a proteção de sua vida e liberdade de raça ou de religião, e realmente, como diz Fauchille (236), a proteção do Direito das minorias deve ser proclamada de uma maneira absolutamente geral, como obrigatória para todos os Estados, mesmo os mais civilizados em todas as porções de seus territórios: toda nação em todos os Estados pequenos ou grandes, fracos ou poderosos deve ser protegida.

\section{LIÇÃO DA HISTÓ- RIA DO DIREITO INTERNACIONAL}

A história do Direito Internacional nos ensina que é inutil combater o princípio das nacionalidades. Quando um povo, com uma concepção nítida dos seus destinos, com aptidão para viver, cheio de forças e ideais, com uma compreensão clara de sua nacionalidade, que é um fato psícológico importantíssimo, deseja tornarse livre não ha obstaculos, não ha fôrças humanas que o vençam: mais cedo ou mais tarde será livre.

$\mathrm{Si}$ os escritores europeus combatem o principio das nacionalidades, é para defender interesses inconfessaveis.

As populações oprimidas hão de se erguer contra a cobiça insaciavel das grandes potências, e reduzir a nada os que combatem o princípio das nacionalidades.

Este, vencedor no passado, será tambem vencedor no futuro. 
O IMPÉRIO BRITÂNICO

I - Manfred Sioto Pintor, Cours, 41 - pag. 309.

2 - Accioli, n. 141.

3 - Nokl BAKer, Courb, T. 19, 1927. V. Le Statute juridique des dominions britaniques dans le domaine du Dr. Int.

4 - Buchet - Le Status des Dominions bri'aniques.
A expressão império não corresponde a uma forma constitucional definida, e a sua significação mudou muito através da história. Podemos dizer que IMPERIO é um vasto território, um composto de varios Estados separados, governados por um Imperador, ou um grupo de territórios, governados por um Estado soberano.

Tratando-se do Império Britânico, verificamos que ele não corresponde na realidade a nenhum tipo preciso e desafia toda classificação, não oferecendo nenhuma semelhança real com qualquer outra organização política existente na atualidade ou de que haja noticia na história (LORD BALFour).

A tendência atualmente é para substituir a expressão "Império" por "Commonwealth". Mas essa expressão não é mais precisa do que o termo "Império", e não corresponde tambem a nenhuma forma constitucional definida.

Deixando de parte peculiaridades que se podem ver na magnifica obra "LE STATUS DES DOMINIONS BRITANIQUES EN DROIT CONSTITUTIONNEL ET EN DROIT INTERNATIONAL", por EDMOND-EDOUARD BUchet (1928), procuremos caracterizar o Império Britânico.

UNIÃO PESSOAL põem: O Império Britânnico é um dicto pela S. D. N. e pelo Direito Internacional.

UNIAOO, REAL

cessariamente uma única pessoa internacional (Conferência Impe-

Não 'é União Real. Os dominios britânicos têm representação distinta na S. D. N., e fora dele não formam nerial - 1926). 


\section{ESTADO FEDERAL}

\section{CONFEDERAÇÃO}

mar-se em Confederacão... federação (Chamberlain, etc.). Os domínios não têm independência completa, e o Império Britânico é considerado uma pessoa internacional. Além disso, é certo que não haveria vantagem alguma em transformar-se o Império em uma Confederação.

Então, pergunta-se, o que serão afinal os dominios britânicos? Não serão eles, por acaso, nações soberanas? Não. E' duvidoso que possam fazer a guerra, e celebrar a paz, e não têm mesmo o Direito de Secesso.

Podemos dizer com Lloyd George que se trata de uma associação livre igual e leal das nações britânicas sob o cetro de um soberano.

o Império baseia-se principalmente na boa vontade de seus membros. Estes não têm vantagem em se retirar dele. Além do mais, ha o vínculo sentimental que liga as nações britânicas, e este laço sentimental é a corôa.

0 que se pode dizer é que o lugar do self governing dominions dentro da Familia das Nações, no momento atual, desafia qualquer defjnição precisa. As relações entre a Grã Bretanha e os dominios não têm precedentes na História, a menos que o império se torne um Estado Federal (237).

\section{A OPINIAOO DE MASSIMO PILOTI} riência da história, vejamos a opinião do ilustre Massımo PILoTI (239). E' atualmente, diz PiLoti, possivel retomar e completar a definição do Império Britânico, tal como foi deduzida da definição dos dominios, dada pela Conferência de 1926.

(237) OpPenheim, I, §94 - b.

(238) Droit de La Paix, Cours, V. 34, pag. 305.

(239) Académie de Droit International, vol. 34, Cours, Les. Unions d'Etats, pag. 525. 
O BRITISH COMMONWEALTH OF NATIONS é uma união real de Estados, livremente confederados, ligados pela fidelidade (Allejeance) ao seu monarca comum, não subordinados uns aos outros, nem no dominio de sua atividade interior, nem no dominio da sua atividade no seio da comunhão do Direito das Gentes, de que são sujeitos.

O COMMONWEALTh, tomado em seu cojunto, é um sujeito de Direito das Gentes, sem ser um Estado. Sua atividade se exerce em consequência de consultas, de acôrdos, entre seus membros, e sobretudo em seguida a acôrdos não obrigatórios, mas praticamente observados.

Esta atividade se realiza por meio de atos convergentes do govêrno de todos os Estados do COMMONWEALTH, ou por meio de atos do Govêrno da Grã Bretanha que os executa em nome e por conta de todos os Estados do COMMONWEALTH.

Esta atividade se exerce não sómente no dominio das relações internacionais, mas no interior do grupo, nas matérias de interesse primordial, como a regulamentação da qualidade geral de súbditos do monarca comum. 


\section{A SANTA SE}

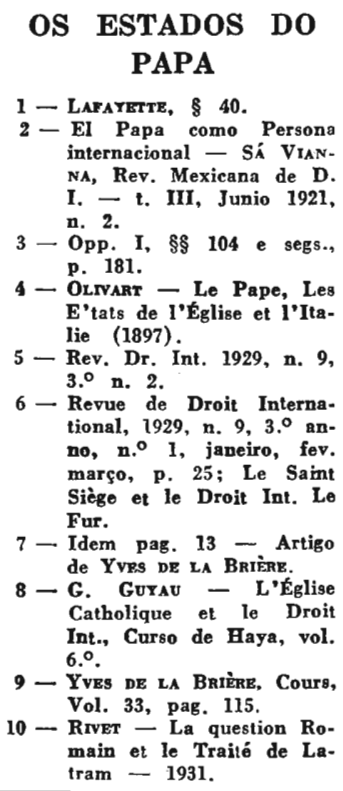
internacional - SÁ VIAN$N A$, Rev. Mexicana de $D$. I. - t. III, Junio 1921, n. 2.

3 - Opp. I, $\S 104$ e segs., p. 181.

4 - Ornart - Le Pape, Les E'tats de I'Eglise et I'Italie (1897).

5 - Rev. Dr. Int. 1929, n. 9, $30^{\circ}$ n. 2.

6 - Revue de Droit Interna. tional, 1929, n. $9,3 .^{\circ}$ anno, n. $0^{1}$, janeiro, fev. março, p. 25; Le Saint Siège et le Droit Int. Le Fur.

7- Idem pag. 13 - Artigo de Yves DE LA Brièrr.

8 - G. GUYau - L'Église Catholique et le Droit Int., Curso de Haya, vol. $6 .{ }^{\circ}$.

9 - Yves DE LA Brtère, Cours, Vol. 33, pag. 115 .

10 - RIveT - La question Romain et le Traité de Latram - 1931 .

\section{SITUAÇAO INTER- NACIONAL}

1 - OPpengeim, I, $\$ 106$.

2-Giogt, R. G. XVIII, p. 604.
Criados os Estados do Papa por PEPINO, O BREVE, e CARLOS MAGNO, em favor de ESTEVAM II e ADRIANO I, pelos quais foram coroados, foi outrora o PAPA um monarca como outro qualquer. Em 1798, por três anos, tornaramse os Estados papalinos uma República, restabelecendo-se, em 1801, o antigo estado de coisas. Em 1809, tornam-se parte do Império Napoleônico, até 1814.

Desta data até 1870 , quando foram anexados ao reino da Itália, permanece o Papa como senhor de seus domínios. Começa, então, um periodo caracterizado pela lei de garantias (OPPENHEIM, I, $\S 105)$.

Tendo uma missão universal, pelo consenso das nações cultas, pela tradição, tinha o Sumo Pontifice uma certa posição internacional, era considerado um verdadeiro monarca. Mas pelo seu caracter especial era a SANTA SE' uma pessoa sui generis, anormal, honorária, de Direito Internacional (240).

(240) Já dizia LAFAYETTE $(\S 40)$ que a personalidade internacional do Papa era de um caracter excepcional, distinguindo-se a sua soberania eminentemente do poder temporal. Salientava já Lafayette a natureza excèpcional da soberanía do Papa e previa a aliança com o Socialismo nas seguintes palavras: " $\mathrm{E}$ diante da obstinada recusa, por parte das grandes potencias, de darem o seu concurso para o restabelecimento do poder temporal, não procurará o Pontificado a alliança do Socialismo, que com algumas correções e sem grandes esforços de subtilezas, póde achar abrigo nos textos do Evangelho? E como resistir ao socialismo elevado pela consagração do Pontifice á categoria de uma doutrina santa. A vitoria do socialismo meteria o mundo civilizado em uma segunda Média Idade. E não foi na Média Idade que o Pontificado tocou ao apogeu de sua grandeza e poder?" 


\section{A OPINIAO DE LORD PHILLI- MORE}

No seu curso, na ACADEMIA DE DIREITO INTERNACIONAL, a f i r m o u Lord Phillimore que é idêntica a posição do Papa á de SUA BEATITUDE 0 PATRIARCA DE CONSTANTINOPLA e

o KALIFA, para os maometanos. Não creio que a missão desses chefes de religião seja idêntica á do Papa. Basta para confirmar o nosso asserto a leitura do trabalho de G. GUYAU - "L'ÉGLISE CATHOLIQUE ET LE DROIT DE GENS” (241).

SITUAÇAO ATUAL
Depois do TRATADO DE LATRÃO (11-2-1929) mudou-se radicalmente a situação internacional da SANTA' SE'.

Foi delimitado um território independente sobre o qual é reconhecida expressamente pelo reino da Itália a plena soberania temporal do PONTfFICE romano. Este território denomina-se "ESTADO DA CIDADE DO VATICANO". O território independente da Cidade do Vaticano é o caracter visivel do Estado soberano.

Tendo TERRITORIO, população, jurisdição exclusiva da autoridade pública sobre a população, poderes legislativo, executivo e judiciário, força armada, autonomia postal, telegráfica, radiotelegráfica e moeda distinta, sob um govêrno com DIREITO DE LEGAÇÃO ATIVA E PASSIVA, que falta á cidade do Vaticano para constituir um Estado e ter personalidade internacional?

Pouco importa que seja pequena a sua superficie territorial e a sua população composta de funcionários pontifícios. Mesmo com caracteristicos sui-generis, a que se refere Yves DE LA BRIÈRE, deparamos com um Estado em condições de ter plena personalidade internacional, de conformidade com os principios tradicionais do Direito das Gentes.

ESTADO NEUTRO

A SOBERANIA DA SANTA SE'
O território do Estado Pontificio foi neutralizado permanentemente.

A soberania da Santa Sé é limitada, bem o sabemos. Mas tambem a noção de soberania ilimitada está hoje desmoralizada completamente. A chamada

soberania, expressão misteriosa e sibilina, é relativa e limitada cada vez mais á medida que aumenta a solidariedade econômica e jurídica dos Estados. vol. 6 .

(241) Cours à l'Académie de Droit International de la Haye, 


\section{OPINIÃO DE LE FUR}

Sustenta o grande mestre LE FUR a doutrina da espiritualização da soberania, aplicando-a á Santa Sé. Outra coisa não sustentavam os Papas na Idade

Média. Diz o ilustre jurista que não só a soberania espiritual não está em contradição com o Direito das Gentes, mas, ao contrário, parece ser para ele motivo para novo e grande progresso, permitindo caracterizar melhor a natureza juridica da Sociedade das Nações, sem território próprio, e, contudo, com soberania.

OPINA YVES DE LA BRIËRE

de convencional e simbólico.

Salientando as peculiaridades do novo Estado, Yves DE LA BrIÉre opina que a soberania territorial da CIDADE DO VATICANO apresenta qualquer coisa

\section{O TRATADO DE LA- TRÃO E O DIREITO INTERNACIONAL PRIVADO}

Não podemos deixar de nos referir aos efeitos do TRATADO DE LATRÃO em matéria de Direito Internacional Privado. Sobre o assunto pode ser consultado com proveito um trabalho magnifico, claro e sintético de NyBoyeT, publicado na "Revue de Droit International", de A. Sottile (1929 - abril e junho, n. $.^{\circ}-7 .^{\circ}$ ano).
Sustentam muitos jurisconsultos que existem direitos fundamentais dos Estados. Mas quando tratam eles de dizer quais são esses direitos fundamentais, entram em grandes divergências. Em

geral, dizem que são fundaraentais os direitos de existência, de independência, de conservação, o direito de intercurso, o de boa reputação etc. Mas, como observa OpPEnHEIM, não ha acôrdo entre eles na enumeração desses direitos que pretendem ser fundamentais. Acha que não existem esses pretensos direitos fundamentais dos Estados.

O Direito Internacional, como já explicamos, ao tratar do seu fundamento, originou-se do consentimento comum dos membros da Família das Nações, desenvolvendo-se historicamente ao influxo da civilização cristã.

Os povos adotaram os princípios cristãos como poderiam adotar quaisquer outros. Observou-se que eram os melhores, os que mais asseguravam as condições de vida e desenvolvimento do indíviduo 
e da sociedade, e que os povos mais adiantados poderiam progredir com esses principios. E assim aconteceu, porque os povos cristãos foram, e são, os mais civilizados da terra.

E mesmo os povos que posteriormente entraram para a Familia das Nações, tiveram que adotar expressa ou tacitamente os princípios cristãos nas suas relações reciprocas. Mas, não existe uma moral absoluta, um direito imutavel. A própria moral cristã tem sido modificada, e grandemente, com o correr dos anos.

Não existem direitos fundamentais, existem Direitos que foram adotados pelos povos civilizados. Observou-se que os povos só podem viver e progredir em sociedade, e que, para um povo viver na sociedade internacional, precisa respeitar o Direito dos outros e limitar a sua liberdade de ação. Todo povo, portanto, pode agir livremente desde que não venha ferir direitos dos outros povos. Vejamos agora quais os principais direitos dos Estados.

IGUALDADE, HONRAS E TfTULOS
A igualdade dos Estados resulta da personalidade internacional. Consequências da igualdade são:

1) - Quando surge uma questão

que tem que ser resolvida pelo consentimento comum dos membros da Família das Nações, cada Estado tem um voto, e um único voto;

2) - Legalmente o voto do Estado mais fraco é igual ao do mais forte;

3 - Em consequência da regra PAR IN PAREM NON HABET IMPERIUM, nenhum Estado tem jurisdição sobre outro plenamente soberano (242).

Conquanto um Estado possa demandar em Tribunal estrangeiro (243), não pode em regra ser demandado, salvo quando aceita voluntariamente a jurisdição do Tribunal estrangeiro, ou se submete a ele, demandando em Tribunal estrangeiro.

HON R A S

Como na sociedade dos indivíduos, na dos Estados ha certas distinções. Hoje essas honras não têm mais tanta importância como no passado. No século XVI e XVII discutiu-se muito a precedência (244).

o Congresso de Vienna de 1815 quis regular a matéria, encontrando dificuldades insuperaveis.

(242) LAFAYETTE, $§ 48$.

(243) Phillimore, II, $\S 113 .^{a}$; Nys; OPPENHeIM.

(244) Droit de préséance - questions de préséance. 
T T T L O S

Buther and Maccost, p. 32.
Quanto aos titulos, estes existiam outrora em larga escala. Gênova e Veneza eram serenas repúblicas, São Marino Serenissima República.

Cada Estado pode evidentemente dar ao seu chefe o título que entender (245), mas este só será reconhecido pelos outros Estados se estiver de acôrdo com a realidade. Em 1871, o rei da Prússia tomou o nome de Imperador da Alemanha; em 1877, o rei da Inglaterra tomou o título de Imperador das fndias.

0 reconhecimento de títulos é facultativo, havendo numerosos exemplos de reconhecimentos tardios e de não reconhecimento.

Pedro, o Grande, tomou, em 1701, o título de Imperador da Rússia, mas esse título só foi reconhecido pela França, em 1745, pela Espanha, em 1759, e pela Polônia, em 1764.

O título de Rei da Prússia tomado, em 1701, somente em 1786 foi reconhecido pelo Papa.

Os Imperadores e Reis são majestades, o Papa é Santidade, segundo determina o Direito Internacional. Mas, além desses títulos, existem outros que são os dados pelos Papas. O rei da França era "Rex Christianissimus"; o da Espanha, depois de 1496, "Rex Catholicus"; o da Inglaterra (1521), "Defensor Fide"; o de Portugal (1748), "Rex Fidelissimus"; o da Hungria (1758), "Rex Apostolicus".

\section{DIGNIDADE} temente. Na sociedade dos Estados como na dos indíviduos a reputação e o bom nome dependem do bom procedimento. $O$ que existe no Estado é uma qualidade, a dignidade. Em consequência da dignidade, que é atributo reconhecido pela Familia das Nações, os Estados nas suas relações observam, pelo costume, entre si, certas cerimônias, e concedem uns aos outros certos privilégios.

\section{Por exemplo:}

1) - Honras e privilégios concedidos aos chefes de Estado;

2) - Exterritoriedade dos agentes diplomáticos;

3) - Respeito a bandeira;

4) - Cerimoniais maritimos.

(245) Gama Lobo (Pr. D. I., Lisbôa - 1865) conceitua o título como sendo os nomes que definem a autoridade, as honras de que se acham revestidos os altos funcionários do Estado, como rei, imperador, etc. Tratamento são as denominações honoríficas que se concedem ás pessoas, que gozam de certos títulos, como Majestade, Alteza, etc. (54). 


\section{INDEPENDENCIA}

LAFAYETTE, \& 47.

A independência é evidentemente um Direito do Estado, tendo como consequência o Direito de legitima defesa, o de intercâmbio e o de jurisdição. A independência ou a autonomia da nação é a inteira e completa liberdade de que ela goza, tanto no govérno dos seus negócios internos como na direção das suas relações exteriores (246).

Em Direito Internacional, usam os autores indiferentemente as expressões independência, liberdade, autonomia e soberania (247).

Observemos, com Fauchille, que os Direitos do Estado são limitados pelo interesse geral ou superior da sociedade mundial (297-1, pag. 510) e que a independência é limitada pela independência das outras nações (248).

\section{DEVERES DOS ESTADOS}

O primeiro dever do Estado é o de respeitar a personalidade internacional de outros Estados que com ele coexistem na comunhão internacional (CRUCHAGA),

não podendo portanto permitir que se preparem no seu território expedições contra outros Estados, ou que nele sejam ultrajados representantes dos vários Estados civilizados coexistentes na Familia das Nações.

Como consequência do dever de respeito á personalidade dos outros Estados, “.. os Estados não poderão adotar nome, bandeira, sêlo, ou qualquer sinal pertencente a outro" (EPITÁcro, Código, art. 20).

O segundo dever é o de mútua assistência, especialmente em relação aos navios que se refugiam em seus portos, em caso de naufrágio, e para facilitar a administração da Justiça em matéria civil e criminal (249).

O terceiro dever é o de intercurso, porque um Estado não tem o direito de se isolar dos demais. Os Estados têm o dever de intercâmbio, mesmo comercial.

Alguns autores, até o século XIX, sustentaram que a recusa por parte de um Estado de entrar em relação com os demais não era contrária ao Direito Internacional (250). Hoje a doutrina que predomina é a de que o Estado não pode se isolar (Alvarez, LapraDELLE).

(246) Lafayette, § 47; Phillimore, I, § 144.

(247) LAFaytTe, \& 47, nota 1.

(248) LAFayetTe, $\S 48$; HaLL, $\$ 11$.

(249) Bevilaqua, I, pag. 113; Cruchaga, pag. 119.

(250) GeffckeN S. Heffeter, § 33. 
(Veja-se Davis, pag. 122. E tambem Vattel, 1, II capitulo, § 24; HaLleck, pag. 404; WoOLSEY $\S \S 25,63,64$; LoRIMER, pag. 230; Kluber, § 69; De Martens, § 139).

Nos últimos anos, apareceu e tem se desenvolvido uma doutrina denominada "doutrina da porta aberta", que permite a cada Estado obrigar os outros a receber seus produtos e a deixar os seus nacionais negociar em seu território.

Foram os Estados Unidos que tomaram a iniciativa dessa doutrina, aplicando-a especialmente á China (251).

o quarto dever é o de proteção aos nacionais no estrangeiro (252).

O quinto dever é o de NÃO INTERVENÇÃO. Esse dever é capital, e o seu cumprimento é condição básica para a existência pacífica da comunhão internacional.

Intervenção, segundo diz OPPENHEIM (pag. 188), é a interferência ditatorial por parte de um Estado nos negócios de outro para mudar uma ordem de coisas.

A regra em matéria de intervenção é a formulada por EprTícro Pessoa: "Nenhum Estado pode intervir nos negócios internos de outros". Mas si nas relações internacionais a intervenção é a exceção, e a não intervenção a regra (DAvis), em que casos poderá um Estado intervir nos negócios de outro? Nunca será justa a intervenção? Quando se justificará a intervenção, e em que condições?

\section{CASOS DE INTER- VENÇÃO \\ LAFATETTB, \& 53.}

Ai comèçam as divergências. Os autores justificam a intervenção em caso extremo (253). Em primeiro lugar a intervenção em legitima defesa (254).

Parece-me que tem razão Diena (255) quando diz que a intervenção não pode nunca ter uma verdadeira e própria justificação jurídica, já que quando esta existe, quando o Estado se ingere, se imiscue em negócios de outro o faz para tutelar um interesse próprio, e tal ingerência não tem um caracter de intervenção.

Conclue Diena dessa forma deduzindo o seu raciocínio da noção aceita por ele do dever de não intervenção; por intervenção se en-

(251) Fauchille, 287-2, vol. I, pag. 487.

(252) Bevilaqua, I, pag. 177; Cruchaga, pag. 120; Pomerox, § 204; HaLL, § 87; SNow, pag. 625.

(253) Pomeroy, Snow, pag. 57; Davis, Wheaton, $\S 63$, etc.

(254) Davis, pag. 99; Twiss, $\S 107$, etc.

(255) Derecho Internacional, pag. 168. 
tende o fato de um Estado, por autoridade própria e sem título ju. rídico especial, imiscuir-se em assuntos internos ou internacionais de outro Estado, para impor-lhe uma determinada solução em caso de controvérsia, ou ainda uma determinada linha de proceder em relação a uma ou mais questões.

Diz Diena que, si acima dos Estados não existe uma autoridade, não deve ser lícito a nenhum membro da comunhão internacional violar impunemente as normas desse Direito. Neste caso, quando a intervenção tenha por fím impedir ou repelir a violação dos princípios do Direito das Gentes, deve ser considerada como justificada e lícita, senão por razões estrictamente jurídicas, pelo conceito de solidariedade que deve existir entre os Estados civilizados, e pelo interesse que a colectividade dos Estados tem em que seja mantido o respeito das normas que regulam as suas relações recíprocas, e tornam possivel a sua coexistência pacífica.

Para que a intervenção feita para impedir ou reprimir as violações do Direito Internacional não assuma os caracteres de uma violação de todos os princípios jurídicos, é necessário que não tenha lugar pela vontade unilateral de um Estado particular, que não pode, por si só, arrogar-se uma supremacia sobre os Estados, fazer-se juiz e executor dos atos por ele realizados.

Para que se justifique a intervenção defensora dos princípios do Direito Internacional, é necessário que ela tenha lugar em forma coletiva, porque só a colectividade dos Estados, a cuja vontade se deve a formação das normas do Direito Internacional, geralmente aplicaveis entre os Estados da comunhão juridica internacional pode ser competente para reprimir as violações do Direito Internacional.

Pode portanto concluir-se, afirma Diena, e com razão, que si a intervenção é um ato anti-jurídico, não obstante deve justificar-se como meio idôneo para manter nas condições presentes da Sociedade dos Estados o respeito das normas do Direito Internacional, quando se realize para impedir ou reprimir a violação de tais normas e sua atuação tenha lugar em forma colectiva (256).

Vamos concluir a matéria de intervenção dando a nossa opinião. A não intervenção é a regra, e a intervenção deve ser a exceção e só se justifica em caso extremo.

(256) A intervenção em prol dos sentimentos de humanidade deve ser colectiva (HALL, §92). Querem contudo alguns limitá-la aos Estados não civilizados (BERnard, Non. Int., pag. 7) o que não nos parece justo (KeBEDGY, Int. 84-5). 
Podemos admitir a intervenção unicamente no caso de violação por parte de um Estado das normas do Direito Internacional e de atos que ofendam os sentimentos de humanidade. Mas para que se justifique a intervenção é indispensavel:

1) - Haver uma intervenção diplomática;

2) - Haver atos tão evidentemente contrários aos princípios morais universalmente acatados, perseguições tão grandes, selvagerias tão espantosas, atos tão excecionalmente contrários aos principios do Direito Internacional que revoltem o sentimento do mundo civilizado; e,

3) - Que a intervenção seja feita por todos os paises que compõem a comunhão internacional, sem uma unica exceção (257).

A intervenção coletiva é a única que se pode justificar. Devemos notar, contudo, que a intervenção não deixa de ser coletiva quando os Estados que compõem a comunhão internacional dão mandato a um deles para intervir em nome e por conta dos demais (258). O Pacto da S. D. N. (art. 23) formula certos princípios de natureza humanitária, e a Comissão Permanente de Mandatos dispõe de boa organização para assegurar que os Estados mandatários executem suas funções de tutela.

(Art. XI seç. 2.a; art. III seç. 3; art. IV seç. 4; art. XXII, Trat. Versailles, art. 419, 427). E mesmo a S. D. N. já agiu eficazmente para prevenir abusos contra a humanidade. (Graham, Humanitária Int., Mrchigan, Law Review, 1924 t. XXII, pag. 324).

RESPONSABILIDADE DO ESTADO

Podemos afirmar que o Estado é responsavel internacionalmente. 0 Estado pode modificar o Direito Interno, mas não o Internacional, e apesar de não haver uma autoridade superior aos Estados para os punir, existem os meios garantidores do Direito das Gentes.

o Direito Internacional exige que o Estado proteja os estrangeiros em seu território, garantindo-lhes a vida, a liberdade, a honra e a fazenda. Não só os individuos, mas tambem a existência, a honra dos Estados estrangeiros devem gozar de proteção e amparo, bem como chefes de Estado e os agentes diplomáticos.

A responsabilidade do Estado é determinada pelo fato de na esfera do exercício de sua soberania ser lesado um Direito que não poderia ser protegido senão por ele.

(257) A intervenção em prol dos sentimentos de humanidade deve ser coletiva (HALL, § 92).

(258) Intervenção Financeira: NItrx, Finanças, II, 341. 
Solve-se a responsabilidade do Estado pela reparação ou pela satisfação. Para que exista a reparação é preciso em geral que, ao ato delituoso do indivíduo, se ajunte a culpa do Estado, que ele não tenha tido as cautelas devidas.

A satisfação não exige culpa absolutamente alguma do Estado. Já a Convenção de Haya (1907), art. 3.\%, dizia que "o beligerante que violar as determinações do seu regulamento pagaria compensação". Responsabilizava somente por atos cometidos por pessoas que fizessem parte das fôrças armadas.

Oppenherm trata longa e profundamente da matéria da responsabilidade do Estado e a ele nos reportamos. Contudo, devemos nos referir á matéria para nós importantíssima, qual a dos danos por operações de guerra. Expondo este tópico verificaremos, ainda que rapidamente, a transformação profunda operada atualmente no conceituar-se o critério da responsabilidade do Estado.

\section{DANOS POR OPERA- ÇõES DE GUERRA}

Esta matéria não pode ser bem compreendida, si não houver um estudo da evolução por que tem passado a idéia do Direito do Estado sobre a propriedade dos cidadãos.

Antigamente, era geralmente aceita a doutrina do dominio do soberano sobre toda a propriedade dos seus súditos. A' medida que se enfraqueceu essa doutrina, e que o chamado dominio eminente foi sendo posto em dúvida, aumentou-se o respeito pela propriedade particular, e nasceu o Instituto da desapropriação, que é de data recente, posterior á revolução francesa, que proclama o respeito á propriedade. A desapropriação fundada na necessidade de se limitar a propriedade, é protetora desta.

Depois da revolução francesa consagrou-se a propriedade como sendo um direito garantido pela lei constitucional. - Essa promessa, porém, foi sempre limitada pelos poderes de polícia, e assim, ainda mesmo na sua obra DIREITO DAS COISAS, LAFAYETTE firma o principio de estar sujeito quanto pertence aos particulares a ser limitado em seu uso pelas obrigações dos poderes municipais, sem ficar por tal obrigado o poder a uma indenização. Em se tratando dos atos pelos quais é destruida ou danificada pelo Estado a propriedade particular, diz LAFayetTe que a doutrina vigente, quando escreveu o seu Tratado de Direito Internacional, isto é, em 1902, era a de não ser o Estado obrigado a resarcir os danos sofridos pelos particulares, si causados pela necessidade de pacificar tumultos e domar revoluções ou guerras civís, mas ajunta que desejavel seria que o fosse $(I, 376)$. Parece-me porém que a questão não pode ser 
colocada neste pé. Não se trata de responsabilidade por ato ilícito. Sabído é que não ha responsabilidade sem culpa. Um deles é o da inversão da presunção da culpa, preceituando a lei que as estradas de ferro, por exemplo, sejam obrigadas a provar não terem tido culpa do desastre ocorrido.

Tambem foi sustentado que ao patrão era que deveria incumbir a prova de não ter sido o desastre ocorrido por culpa dele, mas sim por caso fortúito, ou por culpa do empregado.

o segundo caso é o que foi explicado pela suposta responsabilidade objetiva. Mas hoje explica-se como sendo um risco de negócio, e no risco de negócio assenta o Instituto da Compensação dos acidentes no trabalho.

Assim, pois, não se deve falar em responsabilidade do Estado pelos danos que determinar em luta civil ou externa, como sendo regida pelos princípios que regulam a indenização por atos ilicitos.

Ao caso melhor é aplicar o principio da desapropriação, segundo o qual é lícito ao Estado, em dadas hipóteses, dispor da propriedade particular por necessidade ou utilidade pública. Indiferente é que o Estado peça a propriedade imovel pelo processo de desapropriação mais ou menos moroso que temos, ou que requisite bens móveis ou imóveis no momento de uma guerra ou de comoção intestina.

0 nosso Código Civil ligou os dois casos nos arts. 590 e 591. Pela sua amplitude, é bem claro que o art. 591 abrange não só o emprego da propriedade movel, mas tambem o da imovel. Diz o art. 591 que, em casos de comoção intestina ou de guerra, poderão as autoridades usar da propriedade particular até onde o bem público o exija.

Si é licito á autoridade militar cortar forragem para seus animais, tomar alimentos para as fôrças, apoderar-se de munições pertencentes a particulares, por que motivo não lhe será facultado tomar um imovel afim de dispor dele seja para abrigo, seja para forte, seja para destruí-lo ao intento de conseguir uma pontaria destinada a desalojar ou destruir o inimigo?...

Diz Cuovis, ao comentar este artigo, que a hipótese não é de desapropriação, a qual extingue o Direito de propriedade, mas é de uso da propriedade, salvo o caso de ser a requisição de coisas consumiveis. Ora aí está ao menos um caso em que é manifesta a passagem da propriedade do dominio do particular para o Estado. Ainda pois que não haja sinão uso da propriedade particular, ainda quando a substância da coisa seja conservada, ainda quando só haja uma deterioração pelo uso normal da coisa, á especie devem ser aplicados os princípios da desapropriação. Julgo, pois, que o art. 591 rege precisamente $o$ caso de tomada de propriedade imovel para dela usar ou para destruir, o uso, e o abuso no sentimento juridico técnico 
deste último vocábulo. Entendo pois que o Estado deve pagar como tendo sido desapropriado todo imovel, ou todo movel que houver requisitado solenemente, ou que tenha tomado sem requisição por fôrça da necessidade pública, e julgo que o art. 591 veiu acudir ao desiderato de LAFAYETTE.

Desapropriação no sentido técnico e resţricto só se aplica a imoveis, como se vê nos arts. 590 e 591 do Código Civil. Isto, porém, não impede que sejam seus principios estendidos ás requisições e aos danos sobre móveis.

Tem a maior importância no caso o preceito da lei interna. E assim que OpPenheim, ao estudar o assunto da responsabilidade do Estado pelos danos á propriedade particular consequentes ás guerras civis ou externas, lembra que a França paga todos, quer tenham sido ocasionados por ela, quer pelo inimigo interno ou externo.

Abaixo se verá a que titulo tem ela feito tais pagamentos. Tambem importância capital têm os tratados. E esse mesmo Oppenheim que lembra que diversas. repúblicas sul americanas, em que são frequentes as revoluções e tumultos, têm convencionado em seus tratados relativos á imigração que não respondem pelos danos resultantes dessas perturbações da ordem pública, hipótese em que desaparece qualquer dủvida, porque o contrato faz lei entre as partes.

Fora, porém, da legislação interna brasileira, que é do maior interesse para nós, ha a considerar as leis da guerra estabelecidas pelo Instituto de Direito Internacional de Oxford, em 9 de outubro de 1880.

Dizem essas regras, nos art. 54 e segs., que a propriedade particular deve ser respeitada, e que, quando tomados meios de transportes (barcos, carros, etc.), telégrafos, fábricas, cumpre que sejam restituidos após a terminação da luta no estado em que foram recebidos, e, si impossivel, com indenização do estrago sofrido.

Resta ver o espirito que anima o Direito Internacional moderno a este propósito. OPPENHEIM ocupa-se com os atos dos revoltosos e com a responsabilidade do Estado pelos atos de seus prepostos. Firma em oposição que a regra de outrora era a de que os beligerantes podiam se apropriar dos bens públicos e privados do inimigo, mas que tal regra, hoje obsoleta, foi substituida pela aceita no Regulamento de Haya, art. 46, onde se firmou que a propriedade particular não pode ser confiscada.

Licito é ajuntar que este artigo fala duas vezes no respeito á propriedade particular, e que a coloca ao lado do direito de vida.

Quanto á propriedade do inimigo, aceitando a tradicional classificação, fala OPPENHEIM em imovel e movel. A imovel pode ser tomada unicamente para servir de hospitais, alojamento sem indenização por parte do ocupante. 
Os moveis podem ser requisitados, mas com compensação, após a celebração da paz.

Antigamente, pelo princípio de que a regra deve sustentar a guerra, assim como no processo o vencido paga as despesas, assim tambem era o vencido quem solvia o dispêndio da luta cruenta. Tornando-se, porém, mais dificil o sustento do exército fora do país, começou a dar-se um abrandamento de tal princípio no correr do século dezessete.

OPpenheIm e os demais escritores distinguem a requisição da destruição dos bens dos inimigos por necessidade, pois que a por simples desejo de fazer mal ao inimigo é proibida pelo artigo 23 do Reg. de Haya. Dizem que só a requisição dá lugar a uma indenização. Essa distinção é que, conquanto geralmente aceita, não me parece justa.

Davis vae mesmo até quasi confessar a injustiça dessa maneira de tratar a matéria. Referindo-se á ocupação da propriedade inimiga, diz DAvis que não consagra o Direito Internacional a obrigação de a indenizar, e ajunta que só por política e não por princípio de justiça rigorosa deve ser paga a propriedade do inimigo. Mas o que é digno de menção é que afirma que iliberal e injusta como é esta prática, foi entretanto aceita universalmente por todos os tratadistas do Direito Internacional, e recebeu deles a sanção embora muito a contragosto (pag. 307).

Em se tratando de propriedade do súdito ou de estrangeiro residente, que é equiparado ao súdito, o Direito Internacional reporta-se ás leis locais, ponto importantissimo, seja dito de passo é esta equiparação do nacional ao estrangeíro. Todavia dìstingue ele entre a propriedade tomada ou requisitada para uso público e a que é destruida pelo bombardeamento ou por outras operações de guerra: ha indenização no primeiro caso, mas não no segundo.

Esta distinção é, a meu ver, absolutamente destituida de fundamento, não vejo como distinguir entre a propriedade tomada antes de um combate e a que é ocupada ou destruida em uma operação militar.

E digno de observação que os internacionalistas em geral são de opinião que ás revoltas deve ser aplicado o Direito Internacional tanto quanto é possivel, mesmo que os revoltosos não tenham sido reconhecidos beligerantes.

A beligerância dos revoltosos é outra questão que é examinada pelos internacionalistas, e em geral estão todos de acôrdo em que, desde que os revolucionários, se estabelecem em um território e constituem um govêrno devem ser reconhecidos como beligerantes. Uma nota final, porém, é importantissima, $€$ vem a ser que tudo quanto 
acaba de ser dito é no suposto de terem sido guardadas na guerra as leis consagradas pelo uso e pelos tratados.

Assim como no Direito Interno, a violação de preceitos de polícia torna $o$ ato culposo, assim tambem os atos, mesmo sem cunho de dolo, que foram praticados em contravenção das leis da guerra constituem em responsabilidade o Estado que desrespeitou os principios de Direito Internacional relativos aos meios de ataque e de defesa.

Caso diverso é o da responsabilidade do Estado por atos de revoltosos ou do povo amotinado ou da população que saqueia durante as revoltas ou guerras.

Os princípios do Direito Interno, relativos á culpa são inteiramente aplicaveis á hipótese. Si o Estado teve culpa por não ter usado da diligencia que o Direito exige para a isenção de responsabilidade pelos atos de outrem, pagará o prejuizo.

No caso contrário sua isenção de responsabilidade pelo ocorrido é inegavel. E de repetir que, conquanto pareça, em vista do que é disposto no Direito Interno a este respeito, e quiçá para evitar a questão de fato, costumem alguns Estados consignar em tratados de imigração a sua não responsabilidade pelos atos de revoltosos ou do povo. Neste caso, deve dar-se a aplicação das regras do Direito Interno que regulam o convencionado sobre tais matérias.

Note-se que não é questão, em tal hipótese, de ato do Estado, de operação do poder constituido, de autoridade, e sim de violência da massa popular que muito difere do Estado; ninguem é capaz de confundir Estado com povo, e menos ainda uma multidão sublevada, assim como é dificil haver quem confunda nação com povo e com Estado.

Em conclusão, pois, fique bem assentado que a indenização devida nos casos de desapropriação (de imóveis) e de requisição (de móveis e de imóveis) paga-se pela destruição da propriedade particular nos casos de guerra, e que a indenização, quando não é estatuida em tais circunstâncias, pelas leis internas, é prescrita pelos principios do Direito Internacional, conforme a atual concepção da solidariedade dos cidadãos.

Miguel Cruchaga, que escreveu em 1899, mostra a evolução por que estava a passar, a esse tempo, o pensamento juridico e aponta as opiniões de Frore, Vatel, Calvo e outros, contrários todos a pagar-se a destruição da propriedade particular pelas operações de guerra. Refere que a França sempre fez questão de deixar bem claro que, si pagava os prejuizos sofridos pelos particulares, o fazia unicamente a título de socorro, e de nenhum modo por fôrça de obrigação de indenizar.

0 que parecia justo a CRuchaga era distinguir atos propriamente de guerra, equiparados á fôrça maior, os quais não geram dever de 
indenizar, salvo o caso de inutilidade da operação, e atos voluntários e deliberados do beligerante, que determinam tal indenização.

Longe estava ele ainda da doutrina que veiu a prevalecer após a grande guerra. De 1914 a 1919, promulgou a França diversas leis consagrando o princípio da indenização por quaisquer prejuizos provenientes de operações militares.

Do mesmo modo que no caso de acidentes no trabalho, não foi a indenização assentada na culpa do Govêrno, mas "na igualdade e na solidariedade de todos os franceses nos encargos da guerra".

Com efeito, assim como ha os riscos do negócio, assim como é repugnante á nossa conciência que um operário e sua família cáiam na miséria, por um acidente no trabalho, quando o patrão, sem culpa, é certo, está na opulência, assim como se estabeleceu a solidariedade do patrão e do operário no trabalho, na luta pela produção da riqueza, assim tambem é natural que se reconheça não ser justo salvar-se a pátria á custa apenas de um ou de outro cidadão, que bem pode ser indenizado por todos os interessados na defesa do país. na repulsa aos ataques do solo sagrado da pátria. este o fundamento da indenização por atos em que a comunhão nenhuma culpa tem.

Interessante é lembrar que VATTEL dizia que uma indenização desse genero resultaria em esgotamento do Tesouro Público, tornando-se necessário um imposto para acudir a tão extraordinárias despesas.

O mais admiravel, porém, é dizer VATTEL ser isso impraticavel. De nenhum modo. Todos sabemos que os impostos por guerra são sumamente comuns. Até recentissima data tivemos nós brasileiros de pagar impostos pelas despesas da guerra do Paraguai. Justamente, pois, as premissas de VAtTel levaram a França a tirar delas uma conclusão diametralmente oposta: si para indenização dos danos nascidos da culpa ha necessidade de uma indenização, si esta indenização exige um imposto, concorrendo assim todos com uma pequena parte para a salvação comum, si essa indenização esgota o Tesouro Público, em vez de dizer, como disse VatTel, que tal medida de um imposto especial para pagamento dos danos é impraticavel, disse a França que é realizavel e que é o justíssimo tributo devido por todos por ser nascido da solidariedade que deve ligar todos os membros da communhão social. E a verdade proclamada pela lei francesa de 17 de abril de 1919.

E tempo de considerar um fossil a doutrina segundo a qual os atos do soberano podem dar lugar a uma responsabilidade nem gerar direito a uma indenização: é tempo de deixar a doutrina do domínio eminente segundo a qual o soberano era senhor de todos os bens de seus súditos, doutrina que é mesmo impotente para explicar a desapropriação, salvo si se estabelecer que não tem o par- 
ticular direito á indenização. E tempo de se proclamar que todos os cidadãos de um pais devem concorrer igualmente para a defesa da pátria, com sua pessoa e com seus bens: a destruição da propriedade de um em proveito de todos deve ser compensada por uma indenização ao que viu seu bem sacrificado, embora sem culpa da parte da comunhão. É a única doutrina aceitavel, é a única que se deduz logicamente da obrigação de pagar o Govêrno tudo quanto requisita, é a única compativel com o princípio da indenização de imóveis desapropriados e de móveis ou imóveis requisitados. Tanta razão ha para se indenizar o particular pela perda do imovel que se desapropriou ou que se requisitou, antes do começo do combate para o serviço de guerra, ou do movel que se requisitou antes do inicio das operações militares, como para se pagar o bem que se destruiu no curso de uma batalha, sem prévia requisição.

Coerência só ha nesta doutrina. Os antigos, Fione, Calvo, VatTEL e outros eram de uma incoerência que assombra. Causa admiração o seu ilogismo. 